新日本製鐵第二技研 梶岡博幸, 第一技研 0 松宮徹, 大分技研部 長田修次 広畑製鐵所武田安夫・井垣至弘, 設備技術本部 丹野

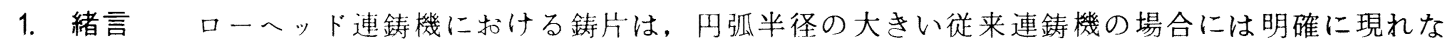
かった特徴ある変形を呈する ${ }^{1 ”}$ 。その結果, 内部割れ発生形態, 鋳片内の歪分布にも特徵が見られる。そ こでこれらの特徵を実機実験扣よび数学モデルを用い定量的に解析して, 各種変形により誘起される歪 について総合奀式 $\varepsilon_{\mathrm{T}}$ を導いた。さらに一方では内部割れ発生限界歪 $\varepsilon_{\mathrm{C}}$ を検討した結果， $\varepsilon_{\mathrm{T}}<\varepsilon_{\mathrm{C}}$ なる 条件で内部割れ発生を的確に防止する方策が確立したので報告する。

\title{
2. 内部割れの形態 - 内部歪の解析結果
}

内部割れは一般に定队弧部括よび矯正部前半で 上面凝固殼に発生し，その軌跡はメ二スカスに向 って凸をなす（Photo. 1)。既報 ${ }^{1)} の$ 長・短片ずれ 変形の理論解析モデルを用いて歪を計算した結果 をFig 1 亿示す。主奀の方向上上記の割れの軌跡 とが一致すること、颃よび定円弧部にも矯正起因 の歪が湖って発生していることが明碓である。

矯正碓の分布についてはロールに突起を施し， これにより鋳片表面に印加されたマークの閪隔を 測ること，および鋳片 $\mathrm{C}$ 断面が矯正により台形化 する量を測定することにより実測した。実測結果 は L / F 面差冷却時の矯正歪に関して, 梁の塑性 曲げ理論に基いて計算した結果と一致した（Fig. $2)$ 。また, 矯正歪が定円弧部にも溯っているこ とも奏測により確認された。

3. 総合歪式・限界垔・割れ防止条件

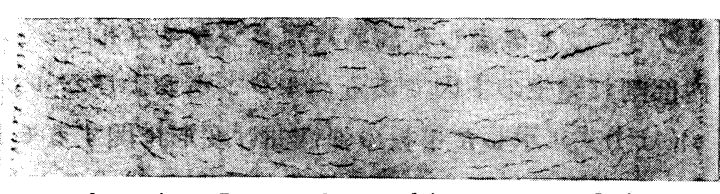

Photo 1. Internal cracking appeared in a $\mathrm{Z}$-cross section at $40 \mathrm{~mm}$ from loose side surface.

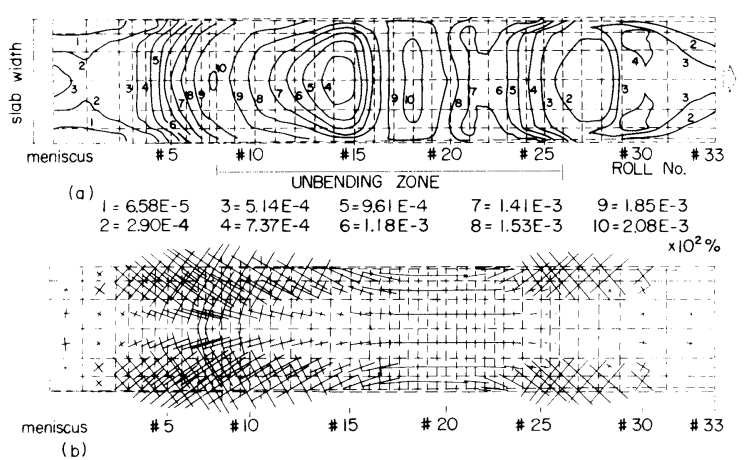

Fig. 1 Calculated unbending strain.(a) distribution of strain component parallel to casting direction(b) direction of principal strain

以上の解析等に基いて総合内部枯式を求めた $: \varepsilon_{\mathrm{T}}=\left\{\beta_{4} \cdot\left(\beta_{1} \cdot \beta_{2} \varepsilon_{\mathrm{u}_{\mathrm{o}}}\right)-\Delta \varepsilon_{\mathrm{u}}\right\}+\varepsilon_{\mathrm{b}}+\varepsilon_{\mathrm{m}} \cdots \cdots(1)$ ここ で $\varepsilon_{\mathrm{u}}, \Delta \varepsilon_{\mathrm{u}}$ : 梁の曲げ理論で計算される $\mathrm{L}$ 面表面矯正歪拉よび表面・内部歪差, $\beta_{2}: \mathrm{L} / \mathrm{F}$ 差冷却効

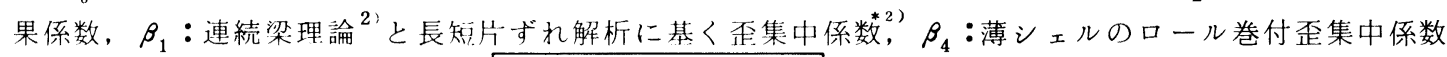
$\varepsilon_{\mathrm{b}}:$ 動的解析法 $^{3)}$ によるハル 一ル泵。一方, 限界芣は融点 の間にある領域）を考虑して 実測値を整理した： $\varepsilon_{\mathrm{C}}=\varepsilon_{\mathrm{C}}$ 。 $\left(\dot{\varepsilon} / 3 \times 10^{4}\right)^{-0.167} \cdots(2), \varepsilon_{\mathrm{C}_{\mathrm{o}}}$ $=6.02 \eta^{-2.13}(\eta \leq 3) \circ \varepsilon_{\mathrm{C}_{0}}=$ $0.770 \times \eta^{-0.258}(\eta>3) \circ \varepsilon_{\mathrm{T}}<\varepsilon_{\mathrm{C}}$ で割れは防此される（Fig.3）。

文献 1) 宿利ら: 本学会にて発表,

2) 安田ら：鉄と銿， 68 ('82),S991.

3) 松官ら：鉄と銓， 68 ('82), A 145 .

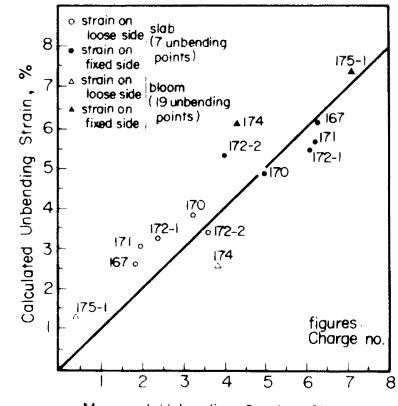

Measured Unbending Strain, \%

Fig. 2 Unbending strain in case of L/F differen tial cooling シング歪, $\varepsilon_{\mathrm{m}}$ : F EM解析によるミスロ 真下の脆化域幅 $\eta(\mathrm{cm}$, 固相線と Z D T

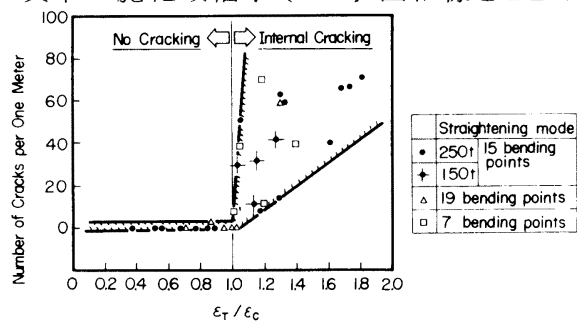

Fig. 3 Internal cracking freaquency vs. normalized strain

*2） S 面差冷却効果をも包含する。 
' 86 - S 994

\section{（202）クリープモデルによるブルーム鋳片の内部割れ解析}

(侏神户製鋼所 鉄鎆技術センター ○安中弘行 横幕俊典

神戸製鉄所蛙名 清 鈴木康夫

要素技術センタ一 久米秀樹 機械事業部 佐々木博史

\section{1. 粕 言}

神戸Na 3 ブルーム C C の生産能力向上を目的として鋳片サイズを $300 \times 400$ から $300 \times 430$ 亿改造し た。改造に先だち，鋳片の伝熱解析およびクリープを考慮した簡易バルシシングモデルを用いて，バルシ ングおよびロールアライメントに起因する内部割れを防止できる 2 次冷却条件を求めた。本解析モデル に基づく 2 次冷却条件の採用により，改造後も内部割れのない鋳片が得られたので報告する。

\section{2. クリープを考虑した簡易バルジングモデル}

内部割れ発生の主因であるバルジングおよびバルジング矯正 歪 $\varepsilon \mathrm{b}$ は(1)式に示した平板の弾性曲げ変形に関するモデルにお けるヤング率 Eにクリープの項を導入した(2)式により求められ る。またバルジング量 $\delta$ は(3)式により求められる。

$$
\begin{aligned}
\varepsilon \mathbf{b} & =\frac{6 \cdot \alpha \cdot\left(1-\nu^{2}\right) \cdot \mathrm{q} \cdot \ell^{2}}{\mathrm{E} \cdot \mathrm{d}^{2}}-(1)\left(\begin{array}{l}
\mathrm{E}=\frac{1}{\mathrm{a}_{0} \cdot \mathrm{t}^{\mathrm{n}}} \\
\sigma=\frac{6 \cdot \alpha \cdot \mathrm{q} \cdot \ell^{2}}{\mathrm{~d}^{2}}
\end{array}\right) \\
& =\left(1-\nu^{2}\right) \cdot \sigma \cdot \mathrm{a}_{0} \cdot \mathrm{t}^{\mathbf{n}}-(2)(3) \\
\delta & =\frac{12 \cdot \beta \cdot\left(1-\nu^{2}\right) \cdot \mathrm{q} \cdot \ell^{4} \cdot \mathrm{a}_{0} \cdot \mathrm{t}^{\mathrm{n}}}{\mathrm{d}^{3}}-(3)
\end{aligned}
$$

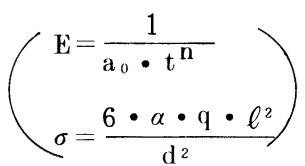

こてで, $\alpha, \beta$ : 形状係数,

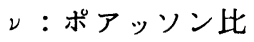

$\mathrm{q}$ : 溶鉵静圧 $\left(\mathrm{kgf} / \mathrm{mm}^{2}\right) \quad \ell$ : ロールピッチ $(\mathrm{mm})$

$\mathrm{d}:$ : エル厚 $(\mathrm{mm})$ $\sigma:$ 応力 $\left(\mathrm{kg} / \mathrm{mm}^{2}\right)$

$\mathrm{a}_{0}$ ：クリープ変数 $\left(\mathrm{mm}^{2} / \mathrm{min} \cdot \mathrm{kg}\right) \mathrm{n}$ : 定数 $\mathrm{t}$ : クリープ時間 $(\mathrm{S})$

また，凝固界面に発生する総歪量 $\varepsilon \mathrm{t}$ は(4)式で示される。

$$
\begin{aligned}
\varepsilon \mathrm{t} & =\varepsilon_{\mathrm{b}}+\varepsilon_{\mathrm{m}}+\varepsilon_{\mathrm{u}} \quad-(4) \\
\varepsilon_{\mathrm{m}} & : \text { ロールのアライメント, 間隔, 摩耗などによる歪 } \\
\varepsilon_{\mathrm{u}} & : \text { 曲げあるいは曲げ矯正による歪 }
\end{aligned}
$$

\section{3. 鋳片温度解析およびクリープ変数}

各種 2 次冷却条件下で差分伝熱解析をおてない, 広面中央部 の鋳片温度推移およびシェル厚を求めた結果の 1 例を Fig. 1 および 2 に示す。また各鋼種のクリープ変数をグリーブル試験 機を用いて測定した結果の 1 例を Fig. 3 に示す。てれよりクリ 一プ変数および定数 $\mathrm{n}$ を求めた。てれらの值を用いて $\varepsilon \mathrm{t}$ を計 算し， $\varepsilon \mathrm{t}$ が内部割れの臨界歪量をてえないような 2 次冷却条 件を採用するてとにより内部割れを防止できた。

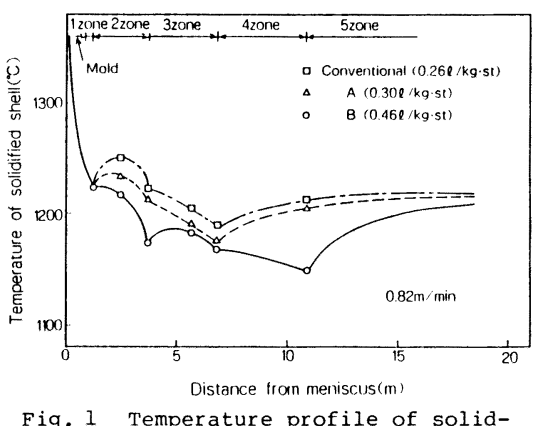

Fig. 1 Temperature profile of solidified shell (calculated)

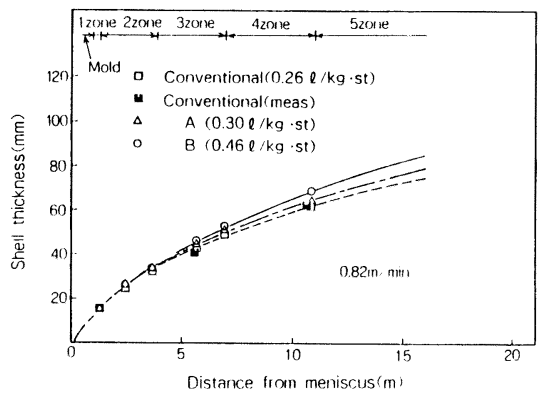

Fig. 2 Shell thickness profile

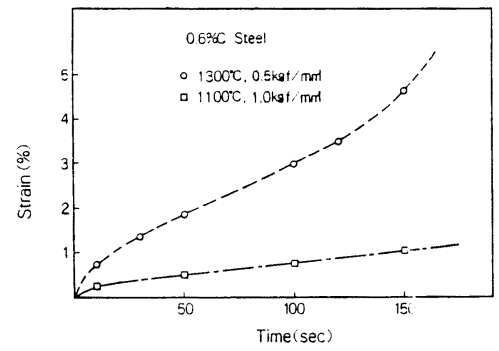

Fig. 3 Effect of time, load, temperature on creep strain

\section{4. 結 言}

てれらのモデル式をもとに，IBM5550で処理できるプログラムを開発し，鋳造条件の設定およびロ ールアライメント管理に活用するてとにより，良好な鋳片内部品質が得られている。 
䎺神戸製鋼所 加古川製鉄所

鉄銅技術センター
副島利行 松尾勝良河合健治

門田克夫 井宮敬吾 ○上田 輝 安中弘行

\section{1. 緒 票}

当所ブルーム連鋳機の生産能力向上を目的に鋳片サイズを拡大した。 $(380 \times 550 \rightarrow 380 \times 600)$ 本報では、サイズ拡大前後の鋳片品質のうち高炭素鋼の中心偏析および鋳片内部割れの調査結果につい て報告する。

\section{2. 高炭素䤡の中心偏析}

Fig.1にサイズ拡大前後のビレットにおける中心 偏析調查結果 ( $3 \mathrm{~mm}^{\phi}$ ドリル使用) を示す。鋳片サ イズ拡大により従来よりも中心偏析が軽减されたこ とがわかる。

また、ビレット中心部組織が従来よりも緻密化し ているととから中心偏析軽減効果は、等軸晶組織の 增加および微細化が促進されたととによると考えら れる。

\section{3. 高炭素鎆の鏻片内部割れ}

Fig.2 亿サイズ拡大前後の鋳片横断面マクロサン プルから求めた内部割れ合計長さを、割れ発生位置 別に示す。

鋂片サイズ挔大に伴ない、当初内部割れが増加し た。主要因としてサイズ拡大によるロール間でのバ ルジング歪の増大が考えられる。Fig.3に示すよう に、弾塑性によるバルジング歪の計算值では歪量が 小さく割れ発生位置との対応が付かない。そこで、 クリープを考虑してバルジング罳を計算した結果、 歪量と内部割れ発生位置が比較的対応した。

内部割れを低减するために、クリープを考虑した バルジング計算を基に、企量を軽减できるような二 次冷却パターンを設定した結果、Fig.2に示すよう にサイズ抎大前と同等以下に内部割れを低减できた。

\section{4. 結 言}

当所ブルーム連鋳の鋳片サイズ拡大後、高炭素鋼 の中心偏析および内部割れについて顕著な差異を認 めた。特に内部割れについては、クリープを考虑し たバルジング計算を基に製造条件を見值した結果、 サイズ拡大前と同等以上の鋳片品質が得られた。

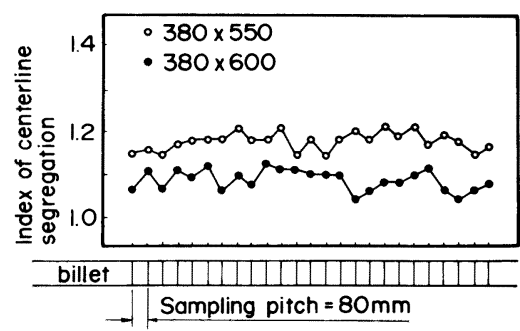

Fig. I Effect of bloom size on centerline segregation of billet $(0.80 \% \mathrm{C})$

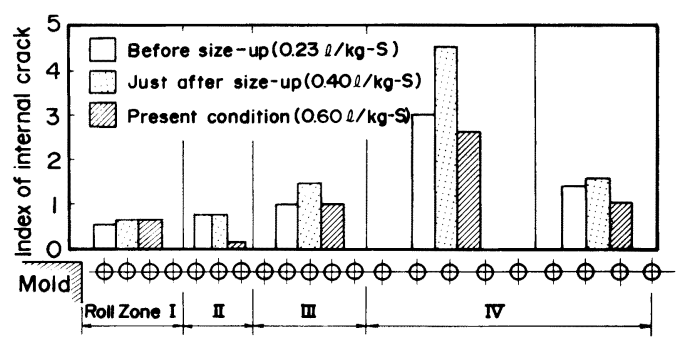

Fig. 2 Effect of bloom size on internal crack.

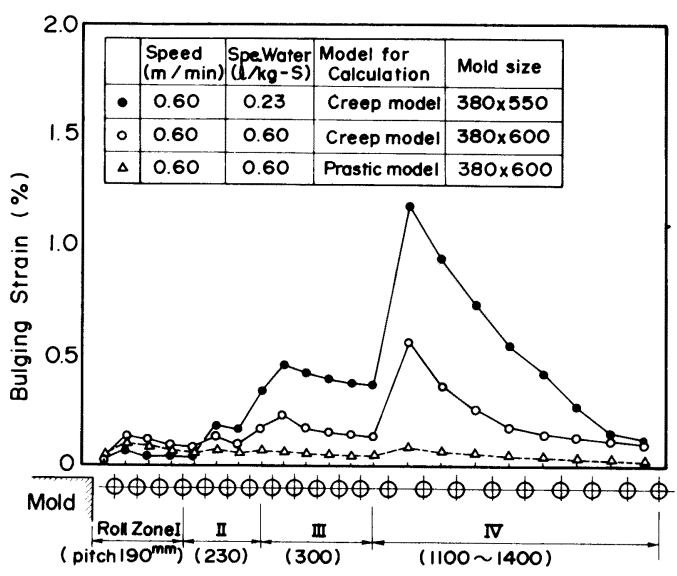

Fig.3 Bulging strain calculated by creep model and elastic-plastic model. $(0.6 \% \mathrm{C})$ 


\section{（204）溶銑の気体酸素インジェクション脱䎢脱燐処理におけるMn 鉱石の還元}

新日本製鐵室蘭製鐵所 井上隆吉田正志

佐藤 久、○米中栄三

\section{1. 緒 言}

当所においては、気固酸インジェクション法による混銑車溶銑脱理、脱燐処理を実施している。 ${ }^{11}$ 今 回脱燐処理時に酸化鉄を鉄 Mn 鉱石で代替し、酸素ガス、脱燐剤と同時にインジェクションした結果、高 $\mathrm{Mn}$ 歩留が得られたので以下に試験結果の概要について発表する。

\section{2. 試験条件}

試験は脱珪処理後除涬し、引き続き、脱燐処理を実施した。鉄 Mn 釷石は、塊釷石を粉砕し使用した。 $\mathrm{CaO} 、 \mathrm{CaF}_{2}$ 使用量は従来法と同一原単位とした。

\section{3. 試験結果}

1). $\mathrm{Mn}$ 歩留 酸素ガスインジェクションにより処理後温度の 上昇に伴ない、Mn 歩留も向上する。（Fig. 1)

2 ) 涬化改善効果 酸素ガスインジェクション下に打ける鉄 $\mathrm{Mn}$ 鉱石の添加により、処理後 $(\% \mathrm{MnO})$ は増加し、未反応 $\mathrm{CaO}$ （\% F CaO）の低下に伴ない、涬化指数が向卜する。（Fig 2）

3). 脱硫率 鉄 Mn 鉱石の添加により、脱硫率は高位に安定す る。これは涬化の促進とともに、（\% $\mathrm{MnO} ）$ 増により、下(1) 式に示す過剩塩基度が増加する事による。（Fig. 3)

過剩塩基度 $=(\mathrm{Ws} / 100) \times\left[(\% \mathrm{MnO})+(\% \mathrm{CaO})+(\% \mathrm{MgO})-1.9\left(\% \mathrm{SiO}_{2}\right)\right.$ Ws Slag volume $(\mathrm{Kg} / \mathrm{TP})$

4). 燐分配燐分配は (\% MnO) の増加にもかかわらず従 来気固酸インジェクションと同じレベルにある。（Fig. 4)

4. 結 言

気固酸インジェクション脱燐処理時に鉄 Mn 鉱石を添加する 事により、高 $M n$ 歩留が得られ、かつ涬化の進行に伴ない、脱 硫効率、脱燐効率も従来之同等以上である。

1). 井上、吉田、佐藤ら 鉄と鋼 71（1985） S 944

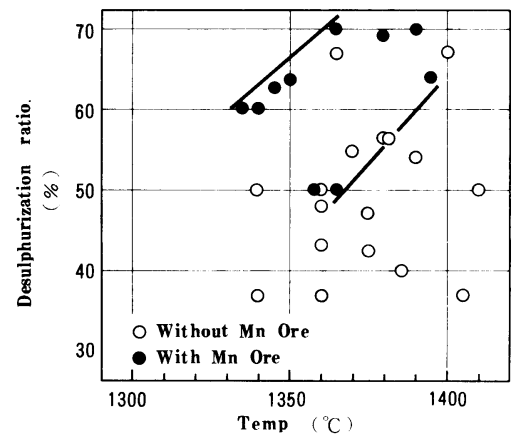

Fig. 3 Relationship between temperature after treatment and desulphurization ratio.

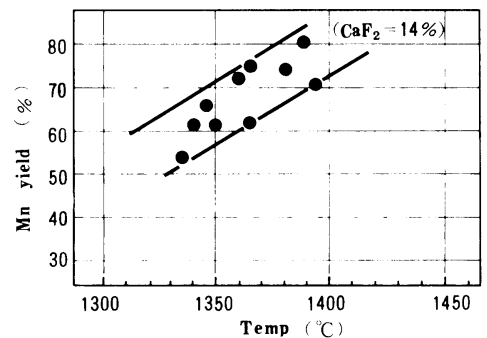

Fig. 1 Relationship between temperature and Mn yield.

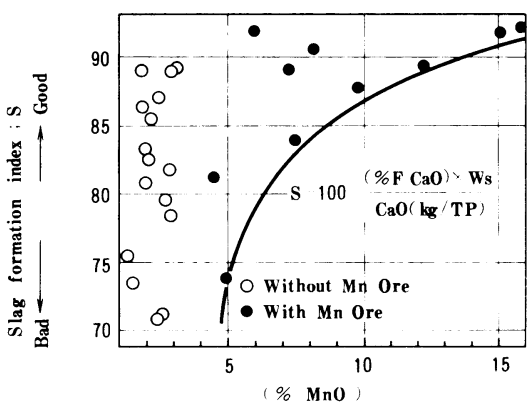

Fig. 2 Relationship between ( $\%$ MnO) and slag formation index.

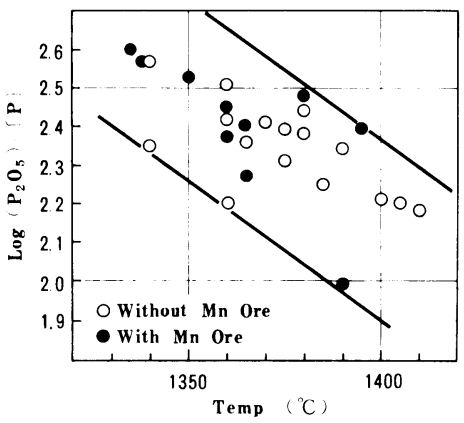

Fig. 4 Relationship between temperature after treatment and $\log \left(\mathrm{P}_{2} \mathbf{O}_{5}\right) /(\mathbf{P})$. 


\section{(205)}

\section{溶鉄予備処理炉における処理制御技術}

侏神戸製鋼所神戸製鉄所塩飽潔川崎正蔵神森章光

青木松秀。羽鹿公則新田正樹

\section{1. 緒 言}

神戸製鉄所では、溶銑予備処理炬（ H 炉）一転炉によ る溶銑処理プロセスが稼動している。今回、H炉にス夕 ティックコントロールを適用し、処理後温度の制御を行 ったところ、処理後 P · S 適中精度が向上したので報 告する。

\section{2. 内 容}

\section{(1)背 景}

神戸製鉄所での溶銑処理プロセスの概要を図 1 に示す。本プロセスは、高炉鋳休での脱Si処理、 $\mathrm{H}$ 炬での脱 $\mathrm{P}$ ・脱 $\mathrm{S}$ 処理および転炬での脱 $\mathrm{C} \cdot$ 昇温 処理により構成されている。H炉では、溶銑の連 続脱 $\mathrm{P}$ - 脱 $\mathrm{S}$ 処理を央施しているが、ての脱 $\mathrm{P}$. 脱 $\mathrm{S}$ 効率は処理後温度に大きく依存する（闵 2 )。 従つて、処理精度を向上させるためには、処理後 温度の適中精度を向上させることが必要条件とな る。そこで、H炉における炣内の熱収支解析を行 い、スタティックコントロールの開発・実機化に よる処理制御を実施した。

(2)スタティックコントロールの開発・実機化

$\mathrm{H}$ 炉における各種副原料( 脱 $\mathrm{P}$ 剂、脱 $\mathrm{S}$ 剂、冷却剂 等) の令却係数の算出、待機時間（処理終了から次于 +ージ処理開始迄の時間) が処理後温度におよばす影 㸷等の熱収支解析を、理論計算および実機における熱 収支データをもとに行い、図 3 に示す精度(処理後温 度推定精度 $+10^{\circ} \mathrm{C}$ ) のスタティックコントロールモデ ル式を得た。本モデル式を央機に適用したとてろ、処 理後温度適中精度の向上に伴い、処理後 $\mathrm{P} \cdot \mathrm{S}$ のバラ ツキも减少した。その状況を図 4 に示す。本スタティ ックコントロールの適用の結果、 $\mathrm{H}$ 炉処理後温度・成 分適中率が向上し、転炉吹鍊の安定化、転炉迅速出䤡 （吹止後成分確認を行わずに值ちに出鋼する方法）の 適用拡大に大きく寄与した。

\section{3. 結 言}

$\mathrm{H}$ 炉にスタティックコントロールによる処理制御を 適用したところ、処理後温度・成分適中率が向上し、 転炉吹錬の安定化、迅速出鋼の拡大に寄与した。

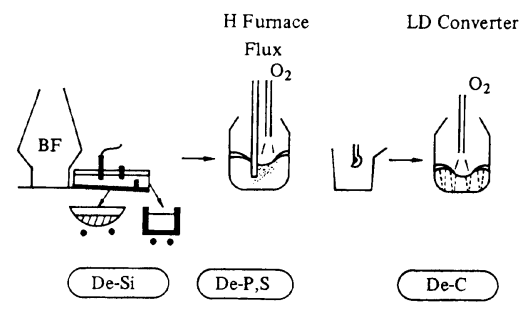

Fig. 1 Hot Metal Refining Process
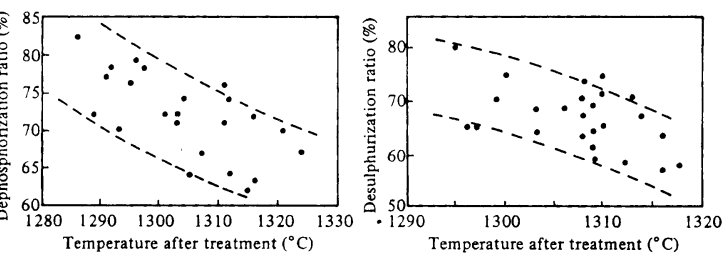

Fig. 2 Changes of De-P, De-S efficiency caused by temperature after treatment

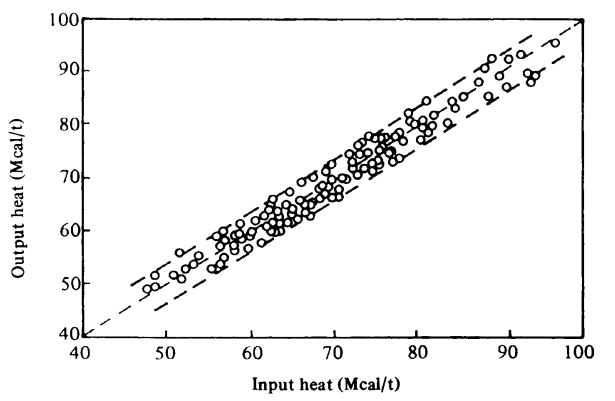

Fig. 3 Relationship between input heat and output heat based on static control model at $\mathrm{H}$ furnace

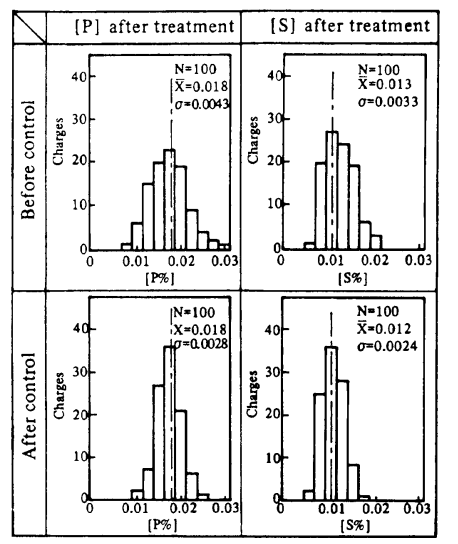

Fig. 4 Effect of static control at $\mathrm{H}$ furnace on the decreasing the deviation of $[\% \mathrm{P}],[\% \mathrm{~S}]$ after treatment 
' $86-\mathrm{S} 998$

(206) トーピート脱燐設備の建設と操業

住友金属工業 和歌山彆鉄所 吉田圭治 永幡 勉 市原 清

黒熊洋二 谷奥 俊 $\bigcirc$ 中山孝司

\section{1. 緒 言}

ステンレス鋼，低 $\mathrm{P}$ 鋼および高炭素鋼のコスト合理化を目的として、既設のトーピード脱 $\mathrm{S}$ インジェ クション設備の機能を增強した溶銑予備処理設備 (脱 $\mathrm{Si}$ ・P・S ) が昭和60年 8 月に稼動した。(脱 $\mathrm{P}$ 能 力 $30 \mathrm{KI} \mathrm{M})$ 特に、脱 $\mathrm{P}$ 時にはキャリアガスの $\mathrm{O}_{2}$ 混合及び酸素上吹きを実施し、既設の溶銑鍋脱燐と

同様、脱 $\mathrm{P}$ フラックスの低減・温度補償に効果を挙げている。本報ではトーピード脱燐設備の建設と操 業について報告する。

\section{2. トーピード脱燐設備}

Tablelに トーピード脱燐設備の主仕様を Fig.l亿概略図 を示す。

本脱燐設備の特徽：

(1) 高炝樋脱 $\mathrm{Si}$ 銑を用い、脱 $\mathrm{Si}$ スラグはV S Cで吸引除去 する。

(2) 脱燐剤は 生石灰・酸化鉄・䖺石・炭酸カルシウム等 Table 1. Outline of hot metal treatment equipment. の混合フラックスを用い、斜行ランスによりインジェク ションする。

（3）キャリアガスに $\mathrm{O}_{2}$ を最大 $80 \%$ 混合し、ランス詰りを防 止するとともに、吹込を安定化する。

（4）上吹きランスを用いて $\mathrm{O}_{2}$ ガスを供給し、処理后温度を 安定化させて、転炬での熱バランスを改善する。

\section{3. トーピード脱燐の操業状況}

F i g. 2 に気体酸素使用比率が温度降下に及ぼす影響を示す。 脱 $\mathrm{P}$ 前温度が $1280 \sim 1350^{\circ} \mathrm{C}$ であるため、温度降下か、 $50^{\circ} \mathrm{C}$ 以内になるよう温度制御し、処理后温度 $1280 \sim 1300^{\circ} \mathrm{C}$ 目 標にしている。また、Fig.3に示す様に、脱 S i 以外に消費 される酸素原単位で脱 $\mathrm{P}$ 量が決まる為、操業安定には上吹酸 素の調整が効果的である。

低 $\mathrm{P}$ 銑はステンレス鋼・ 低 $\mathrm{P}$ 銅・高炭素鎆に供給し 溶製コストの低減に寄与し ている。

\section{4. 結 言}

溶銑脱 $\mathrm{P}$ 時に $\mathrm{O}_{2}$ ガスを有 効に用いて、温度制御しつ つ、安定した脱 P 処理を実 現した。

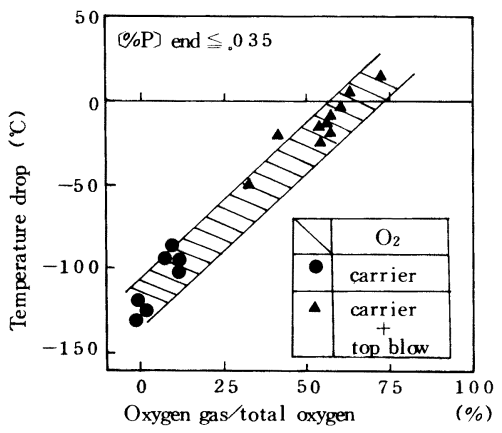

Fig. 2 Effect of oxygen gas ratio in total oxygen source on temperature.

\begin{tabular}{|l|lr|}
\hline & \multicolumn{2}{|l|}{ Specification } \\
\hline \hline Heat size & $90-110$ Ton Torpedo \\
\hline Slag-off & Vacuum slag cleaner \\
\hline \multirow{2}{*}{ Injection } & Differential pressure control led system \\
\cline { 2 - 3 } & Feeding rate & $\max .400 \mathrm{~kg} / \mathrm{min}$ \\
\hline $\mathrm{O}_{2}$ gas & Carrier & $\max .4 \mathrm{Nm} / \mathrm{min}$ \\
\cline { 2 - 3 } & Top blow & $\max .40 \mathrm{Nm}^{8} / \mathrm{min}$ \\
\hline \multirow{2}{*}{$\begin{array}{l}\text { Dust } \\
\text { collector }\end{array}$} & $\begin{array}{l}\text { Bag filter type } \\
\text { Capacity }\end{array}$ \\
\hline
\end{tabular}
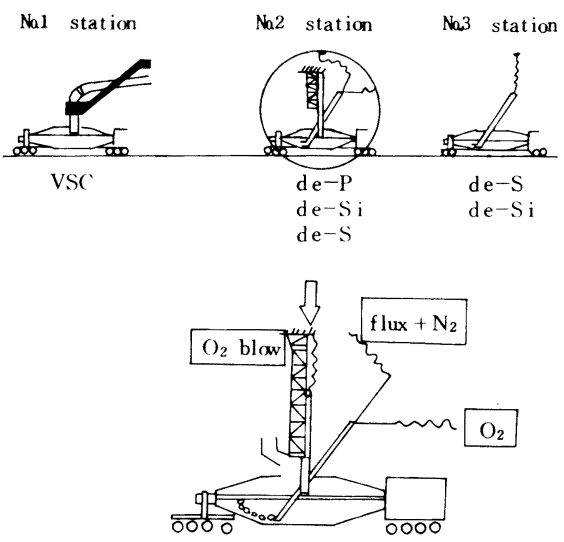

Fig, 1 Schematic diagram of equipment.

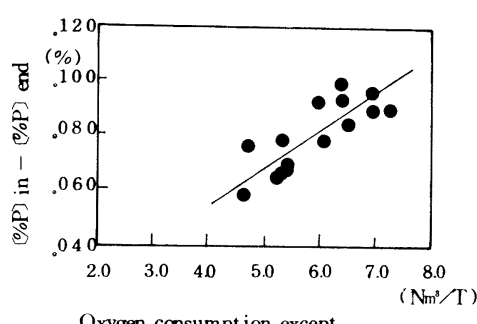

Oxygen consumpt ion except oxygen consumed for desiliconization

Fig. 3 Effect of oxygen consumption on dephosphorization. 
(207) 溶銑尒備処理の実機におけるンー夕灰と石灰系脱 $\mathrm{P}$ 剂の比較

日新製銅侏県製鉄所

\section{1. 楮砉}

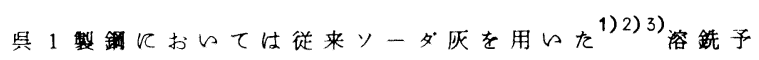
備処理を行なっていたが,ての程石灰采脱 $\mathbf{P}$ 殽の使用を 開始し，実機におるとれら2つの脱 $\mathrm{P}$ 郕の比較を行な つたので報告する。

\section{2. 探莱条件}

彆造プロセスをFig. 1 亿, 脱 P 㓲の組成をTable 1 亿示 す。

\section{3. 内 容}

石欧系およびン一名欧の場合の脱 $\mathrm{Si}$ 外の供給固酸量と

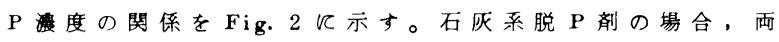
者儿直線関係があるが, ソ一夕灭の場合直楾関係はみら れない。従ってン一斥灰と異なり, 石灭系脱 $\mathrm{P}$ 郕の場合, 脱 P反応は主飞Pの搪散律速飞支配されている。

塩基度として $\left\{(\mathrm{CaO})+2\left(\mathrm{Na}_{2} \mathrm{O}\right)\right\} /\left(\mathrm{SiO}_{2}\right)$ を用い， $\log \left(\mathrm{P}_{2} \mathrm{O}_{5}\right) /[\mathrm{P})$ と塩基度の関保を Fig. 3 亿示す。石灰 柔脱 $\mathrm{P}$ 用,ソ一夕灰共飞塩基度を 5 とするととにより。 $\log \left(\mathrm{P}_{2} \mathrm{O}_{5}\right) /(\mathrm{P})$ は上限を示し, 脱 $\mathrm{P}$ 飞は十分てある。 処理後の温度と $\log \left(\mathrm{P}_{2} \mathrm{O}_{5}\right) /(\mathrm{P})$ の関係を Fig. 4 飞示 す。石欧系の場合，佐野らの報告值 ${ }^{4)}$ やソ一夕灭による 操業の場合之比較し, 温度依存性加小さく，操業温度域 ては温度の影警を在とんど受けない。この結果，石灰系 脱 $\mathrm{P}$ 郕を使用する場合, 気酸を用いて処理後の温度を上 げる事がてを，転妒の熱裕度を增す事がてをる。

\section{4. 結 曹}

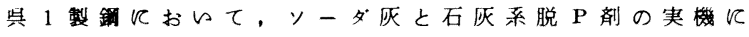
おける比較を行なった。との結果をるとにン一无灰から 石灰系脱 $\mathrm{P}$ 戍を主体とした操業に切り換え,コストダウ ンを達成している。

参考文献

1) 安井5; 鉄と鑇, 71(1985)，S945

2) 安井 万; 第 3 回日中鉄銅学術会議资料

3）安井与；日新製技報，53(1985)，P. 47

4）佐野 与；鉄と鍓，69(1983)，P. 1741

5）佐野ら；鉄と鎆，69(1983), S 175
○加藤周一

安井

高橋 浩

$$
\text { 星記男宮川保重 }
$$

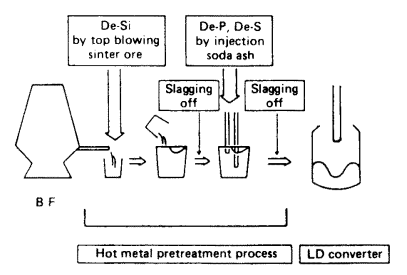

Fig. 1 Schematic flow of No. 1 steelmaking shop Table 1 Flux composition ( 8 )

\begin{tabular}{|l|c|c|c|c|}
\hline & $\mathrm{CaO}$ & E.P. dust & $\mathrm{CaF} 2$ & $\mathrm{Na} 2 \mathrm{CO} 3$ \\
\hline Lime base flux & $40 \sim 55$ & $40 \sim 60$ & $5-11$ & - \\
\hline Soda ash & - & - & - & 99.5 \\
\hline
\end{tabular}
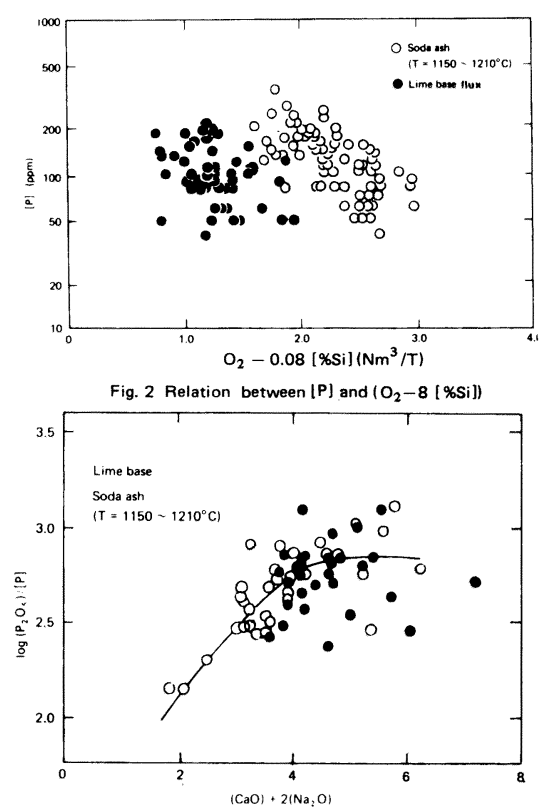

Fig. 3 Relation between $\left\{(\mathrm{CaO})+2\left(\mathrm{Na}_{2} \mathrm{O}\right)\right\} /\left(\mathrm{SiO}_{2}\right)$ and $\log \left(\mathrm{P}_{2} \mathrm{O}_{5}\right) /(\mathrm{P}]$

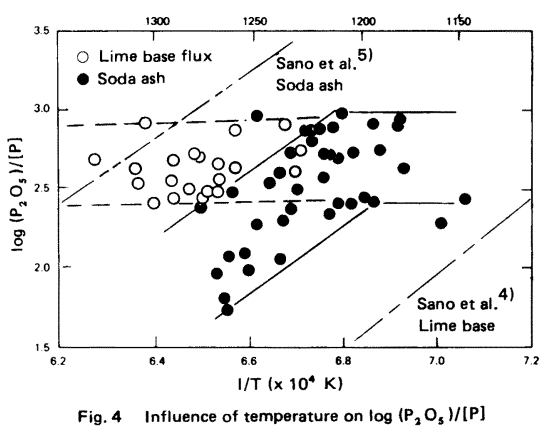

Fig. 4 Influence of temperature on $\log \left(\mathrm{P}_{2} \mathrm{O}_{5}\right) /[\mathrm{P}]$ 
(208)2.5ton試输妒に打ける転妒洋系フラックスによる溶銑脱りん举動

（襩合吹鉷転妒を使った溶銑脱りん法の開発第1報）

住友金属工業捴合捕研究所

I. 暂䓂

溶鉄脱りんフラックスとして転炉洋系を用いる場合の脱燐能につい

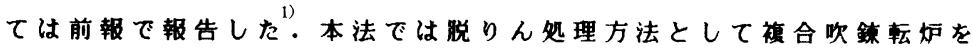
用いる方法について検討した。

II . 二段向流操作法

最む少ないスラグで脱りんするには連続式向流操作が理想であるが， 実現は哑かしい，そこで多段向流操作法で行なった場合の段数 nとス ラグ娍少量の関係をFig.1に示す．段数が增加すると共にスラグ量が 減少するが，1段処理を 2 段処理にするのが労少なくて効果が大きい. 今回娭討したフロセスの既念図をFig.2に示す．本フロロスをSRP (Simple Refining Process) と呼んでいる.

III. 実毁方法

試输転炉を使用し，2tonの脱珪溶鉄（Si:0.1 0.2\%, P:0.1\%)

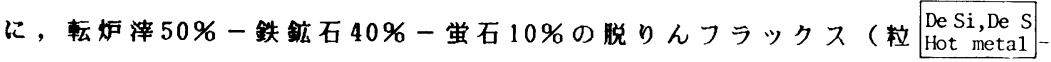
径一 $20 \mathrm{~mm} ） 50 \mathrm{~kg} / \mathrm{t}$ を妒口より一括投入し，妒底Ar港拌を行ないな がら上吹ランスを用いて少量の酸素 Table 1。BOF slag composition (約 $0.5 \mathrm{~N} \mathrm{~m}^{2} / \min \cdot t$ )を上吹するとい う方法で実験を行なった。用いた転 妒涬の成分をTable 1 に示す。 used $(\%)$

\begin{tabular}{|c|c|c|c|}
\hline $\mathrm{Ca} 0$ & $\mathrm{SiO}_{2}$ & $\mathrm{~T} \cdot \mathrm{Fe}$ & $\mathrm{P}_{2} \mathrm{O}_{5}$ \\
\hline $35 \sim 45$ & $5 \sim 6$ & $24 \sim 30$ & $0.7 \sim 1.9$ \\
\hline
\end{tabular}

IV . 実験結果と考察

1. 妒底拱拌によりフラックスは 5 分以内に洋化完了し, 処理後 $[P] \leqq$ $0.010 \%$ で低下した（Fig.3）。姖底港拌を多くすると，処理時間 10 分 で $[P] \doteqdot 0.010 \%$ で低下できた。

2. Table 2 に示すように処理後スラグ中 の $\left(\mathrm{P}_{2} \mathrm{O}_{5}\right)$ は $79 \%$ 高くなった。この時 の $(P) /[P]: 350 \sim 400$ あり，フォスフ エイトキャバシティー $\mathrm{C}_{\mathrm{PG}}$ は $10^{22}$ 前後で

Table 2. Slag composition after treatment (\%)

\begin{tabular}{|c|c|c|c|}
\hline $\mathrm{Ca} 0$ & $\mathrm{SiO}_{2}$ & $\mathrm{~T} \cdot \mathrm{Fe}$ & $\mathrm{P}_{2} \mathrm{O}_{5}$ \\
\hline $33 \sim 45$ & $16 \sim 19$ & $6 \sim 16$ & $7 \sim 9$ \\
\hline
\end{tabular}

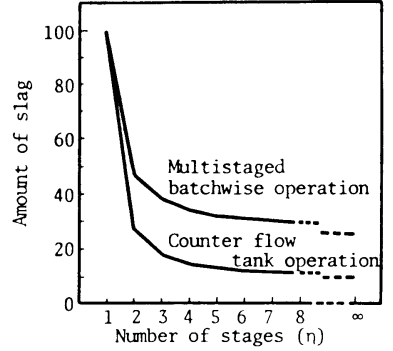

Fig.1 Relation between amount of slag and number of stages in counter flow tank operation

$\mathrm{O}_{2} \quad 0.5 \mathrm{Nm} / \mathrm{min} \cdot \mathrm{t} \quad \mathrm{O}_{2} 3 \mathrm{Nm} / \mathrm{min} \cdot \mathrm{t}$

\section{Iron oxide
Fluorspar}

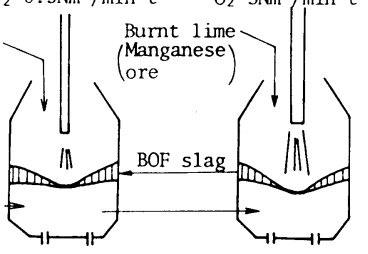

Dephosphorization Decarburization Fig.2 Schematic of SRP

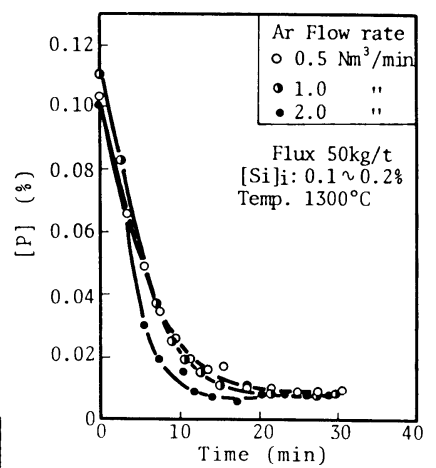

Fig.3 Dephosphorization behaviour in SRP

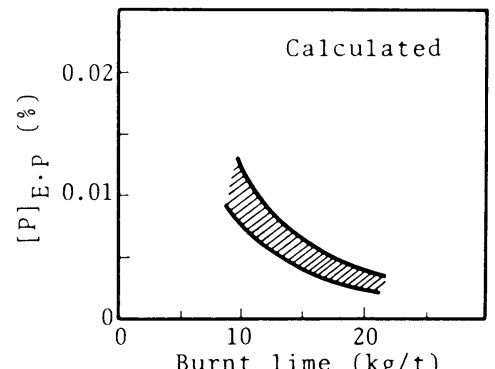

Fig.4 Relation between phosphorus at end point and amount of burnt lime in BOF. 
（209） $160 \mathrm{~T}$ 転炉における溶銑脱りん試験結果

（䙓合吹鉷転炉を使った溶銑脱りん法の開発第2 報)

住友金属工業侏) 和歌山製鉄所 $\bigcirc$ 守屋哲也 松村禎裕 加藤木健

\section{1. 緒言}

前報 ${ }^{1)}$ 2) では転炉㳯系 $\mathrm{f} 1 \mathrm{u} \times$ を用いて溶銑脱りんを 行jS R P (Simple Refining Process)の基本概念 及び $2 \mathrm{~T}$ 転炕での試験結果について報告した。本報で は、この試検結果に基づき、160 160 上底吹転炉( $\mathrm{STB}$ 炉) においてスケールアップ試験を行い、実機への適用に ついて検討した。

\section{II. 試医方法}

STB 炬に、脱 S i溶鏡 ( S i : 0.1 0.3\%, P : 0.1\%) を 注銑後、転炉掻 $25 \sim 33 \mathrm{~kg} / \mathrm{t}$, 鉄鉱石 $20 \sim 24 \mathrm{~kg} / \mathrm{t}$, 木 タル石 $5 \sim 8 \mathrm{~kg} / \mathrm{t}$ を同時に投入し、底吹ガス筧拌 $\left(\mathrm{N}_{2}: 0.06 \mathrm{Nm}^{3} / \mathrm{min} \cdot \mathrm{t}\right)$ を行いながら上吹ランスにて酸素 を $0.5 \sim 1.0 \mathrm{Nm} / \mathrm{min}$ ・

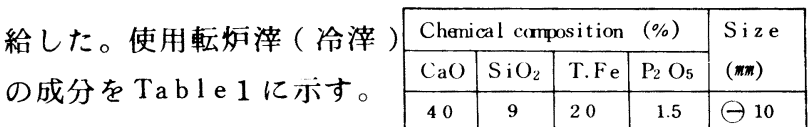

\section{III. 武験結果と考察} 佐藤光信 森 明義

1. 脱りん処理中はスロッピングもなく安定した精鍊であった。

2. $10 \sim 15$ 分の吹鍊にて〔P〕 $=0.015 \sim 0.025 \%$ が得られ、SRP が実機においても成立することが確認された。（Fig．1）

3. 脱りん時の脱炭量は、0.5 0.6\%程度に抑制する事ができ た。(F i g. 2)

4. 溶鋵〔 $\mathrm{S}$ i が $0.3 \%$ と高い場合でも $\mathrm{f} 1 \mathrm{ux}$ を増量すれば、 脱りん率 $80 \%$ が達成可能であった。( F i g. 3)

5.上吹酸素量を調節する事により、吹鍊中の温度は自由に制 御する事ができた。（Fig．4）

6. 処理後のスラグ中 $\mathrm{P}_{2} \mathrm{O}_{5}$ Table2 Slag composition は $5 \%$ 以上であり、十分 に転炉洋の脱 $\mathrm{P}$ 能を活用 できた。（ T a b l l e 2$)$

\begin{tabular}{|c|c|c|c|}
\hline \multicolumn{4}{|c|}{ Chemical composition } \\
\hline $\mathrm{CaO}$ & $\mathrm{SiO}_{2}$ & $\mathrm{~T} . \mathrm{Fe}$ & $\mathrm{P}_{2} \mathrm{O}_{5}$ \\
\hline 32 & 15 & 18 & 5.8 \\
\hline
\end{tabular}

N. .まとめ

S R P は $160 \mathrm{~T}$ 規模の上底吹転炉においても十分に成立するて とが判明した。

（参考文献） 1 ) 松尾亭; 鉄と鎆 72（1986）S209

2 ) 松尾ら; 鉄と銿72（1986）本講演大会発表予定

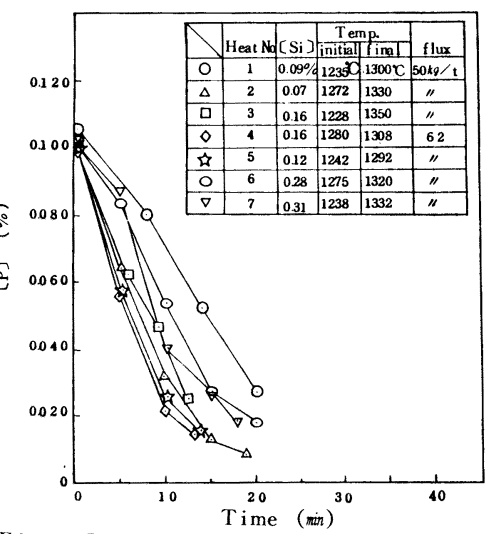

Fig. 1 Dephosphorizat ion behavior i n SRP (160T STB)

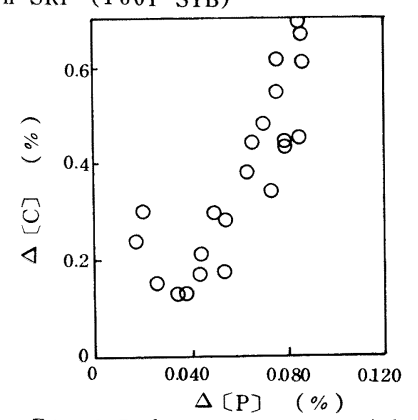

Fig. 2 Relat ion between $\Delta[P]$

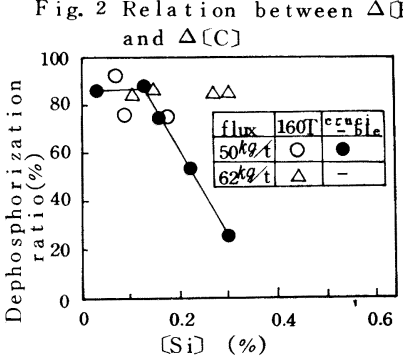

Fig. 3 Effect of H.M.[Si]

on Dephosphorization

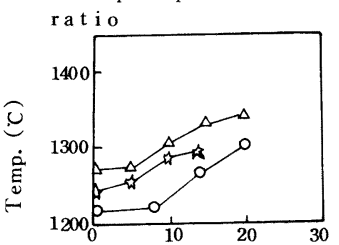

Time (min)

Fig. 4 Change of H.M. temperature during Dephosphorizaion 
住友金属工業 和歌山擎鉄所 $\bigcirc$ 山田統明 中山孝司 松村禎裕 市原 清 加藤木健

東京本社南村八十八

\section{1. 緒 专}

溶銑予備処理に於て、現在広範に用いられている石灰系脱 $\mathrm{P}$ 剤は、その保有する脱 $\mathrm{P}$ 能力を充分活用 されているとは云えず、改善の余地があると考えられる。すなわち、平衡論的には脱 $\mathrm{P}$ スグのキャパ シティは充分であるのに対し、脱 $\mathrm{P}$ 速度が不充分である為にてれにより系の脱 $\mathrm{P}$ 挙動が律速され、脱 $\mathrm{P}$ 凪の原単位低減および処理時間短縮の阻害要因となっている。以上の観点から、今回実炬規模での脱 $\mathrm{P}$ 洋の脱 $\mathrm{P}$ 能力を確認するべく、高 $\mathrm{P}$ 銑の石灰系脱 $\mathrm{P}$ 郕による脱 $\mathrm{P}$ 試験を $50 \mathrm{~T}$ 鍋を用いて実施した。

\section{2. 武医方法}

Fig. 1 にテストフローを示す。脱 $\mathrm{Si}$ 鏻に FeP を添加し て . 200 . $300 \% \mathrm{P}$ に調整后、生石灰・酸化鉄・䖺石の フラックスインジェクションとO $\mathrm{O}_{2}$ 上吹きを実施した。

\section{3. 結 果}

Fig. 2 に 高 $\mathrm{P}$ 銑 ( $(\mathrm{P}\rceil=.200 \sim .300 \%)$ と通常銑 $(\mathrm{P}\}$ $.100 \%)$ の脱 $\mathrm{P}$ 時の成分・温度変化を比較して示す。通 常銑の場合に比較して 溶銑 $\mathrm{P}\}=.025 \%$ に到達する為の フラックスは、 $[\mathrm{P}]=.200 \%$ 約 $10 \mathrm{~kg}$ T 增、 $[\mathrm{P}]=.300 \%$ で $15 \mathrm{~kg} / \mathrm{T}$ 増と約 $30 \%$ 以内の増量に留まった。

\section{4. 考 漂}

Fig. 3 に処理中の酸素バランスを $[\mathrm{P}]=.100 \%$ と $.300 \%$ の場合とを比較して示す。両者の供給酸素に占 める酸素ガス比率はほぼ同等に設定した。初期 $[\% \mathrm{~S} i]$ がほほ同じ場合、初期〔〔P]の高い方が、脱 $\mathrm{P}$ 酸素効 率が向上している。

そてで、Fig.4に 高 $\mathrm{P}$ 銑の脱 $\mathrm{P}$ 后のP 分配を 通 常銑と比較して示す。塩基度が $4 \sim 5$ の範囲で 高 $\mathrm{P}$ 時の $\mathrm{P}$ 分配は 通常銑と比較して $1.7 \sim 2.4$ 倍と大巾 に向上していることが 判る。とのととは 逆 に通常銑の脱 $\mathrm{P} に$ 於 いても脱 $\mathrm{P}$ スグは $\mathrm{P}$ 受容力に余力を持っ ている事を示している。

\section{5. 結 雼}

石灰系フラックスに よる高 $\mathrm{P}$ 銑の脱 $\mathrm{P}$ は脱 P 効率が通常銑よりも 極めて高い事が判った。

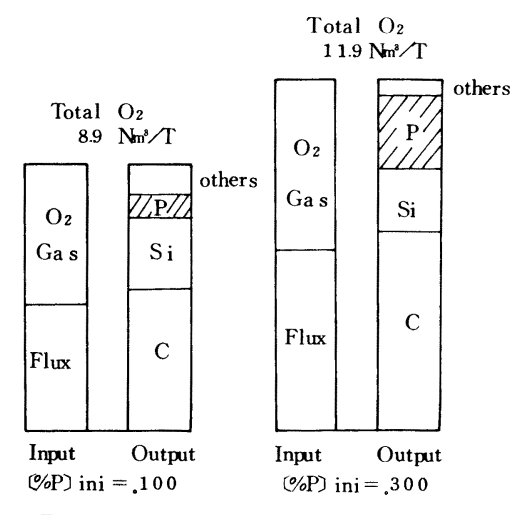

Fig. 3 Oxygen balance

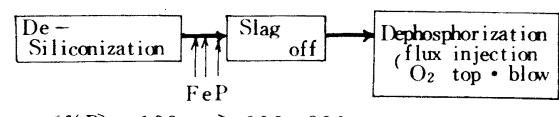

$[\% \mathrm{P}]=.100 \Longrightarrow .200-.300$

Fig. 1 Test flow

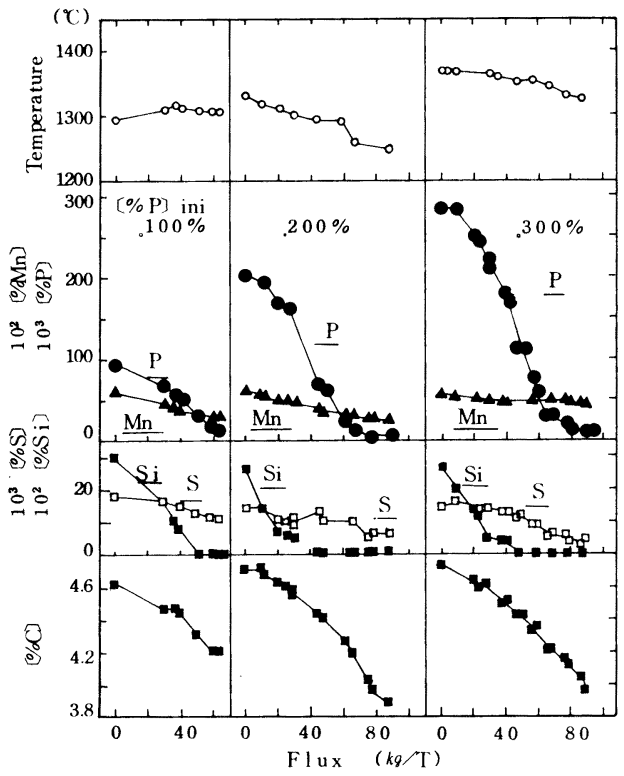

Fig. 2 Behavior of temperature and compositions during dephosphorization treatment.

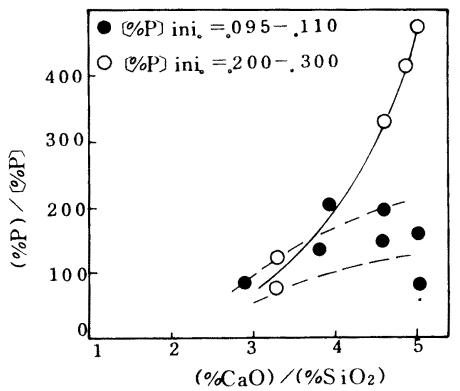

$\mathrm{Fig.} 4$ Influence of basicity on phosphorus distribution. 
(2I I) $\mathrm{CaO}-\mathrm{CaF}_{2}-\mathrm{CaCl}_{2}-\mathrm{Fe}_{2} \mathrm{O}_{3}$ 系フラックスの悦りん能

（石灰系フラックスによる含クロム溶鉄の脱りん法の䦕発 第 1 報）

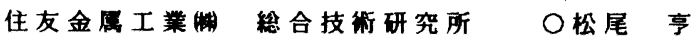

\section{I . 緒 䂴}

含クロム楁鉄の帨りんのうち, Ba0系フラックスを用いる方法にっ いては睌に報告した。一方, $\mathrm{Ca} 0$ 系フラックスを用いる方法についてむ

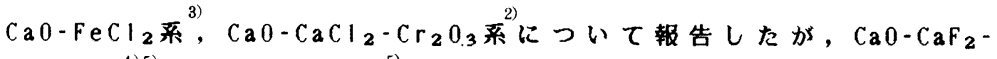
$\mathrm{Cr}_{2} \mathrm{O}_{3}$ 系, $\mathrm{Ca}$ - $\mathrm{Ca}-\mathrm{NaF}-\mathrm{Cr}_{2} \mathrm{O}_{3}$ 系についても検討がされている. 今回主 としてクロム楁鉎を対象に， $\mathrm{CaO}-\mathrm{CaF}_{2}-\mathrm{CaCl}_{2}-\mathrm{Fe}_{2} \mathrm{O}_{3}$ 系フラックスを用 いる方法を検討した。

\section{II . 実梌方法}

タンマン妒を用い, Mg0ルツボ内でTable 1 に示す成分の含クロム 溶铁 $2 \mathrm{~kg}$ を大気溶解し，所定の温度（主として $1500{ }^{\circ} \mathrm{C}$ ）に調整した後， $\mathrm{Ca} 030 \%-\mathrm{CaF}_{2}-\mathrm{CaCl}_{2} 100 \mathrm{~kg} / \mathrm{t}$ を添加し, Mg0バィブを用いてArバブリング摫拌を 行ないながら $\mathrm{Fe}_{2} \mathrm{O}_{3} \quad 20 \mathrm{~kg} / \mathrm{t}$ を分投すると いう方法で実糇を行なった。

Table 1. Composition of
metal used $(\%)$
\begin{tabular}{|c|c|c|c|}
\hline$C$ & $\mathrm{Si}$ & $P$ & $\mathrm{Cr}$ \\
\hline $2 \sim 6$ & $<0.1$ & 0.05 & $0 \sim 25$ \\
\hline
\end{tabular}

III. 実給結果

1. $\mathrm{Fig} .1$ に示すように, 媒溶唷としては, $\mathrm{CaF}_{2}$ あるいは $\mathrm{CaCl}_{2}$ 単独 でも良好な脱りんが進行したが，これらを併用した場合の方がわず かに帨りんが安定した。

2. 㟋りんに及ぼす処理温度の影慗については，Fig.2に示すょうに，低温 程脱りん良好となった。しかしその影慗の度合はBa0系の場合のそれょり 小さかった。

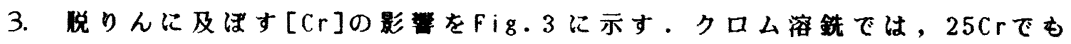
良好な跘りんが進行した。

4. 㟋りんに及ほす［C]の影帮をFig.4に示す。[C]が減少すると共に急 激に脱りん事か低下する㑯向を示し, 碓井らの年 良く一致した。

5. 本フラックスを用いてクロム客銑 $(16 \mathrm{Cr})$ を $1500{ }^{\circ} \mathrm{C}$ で跘りんする場合の りん分配比 $((P) /[P])$ は $20 \sim 25$ あった。

\section{IV . 結言}

[C]が和に近い含クロム溶鉄の㟋りんには, 酸化剂として安俩で取扱い の容易な $\mathrm{Fe}_{2} \mathrm{O}_{3}$ を用いた $\mathrm{CaO}-\mathrm{CaF}_{2}-\mathrm{CaCl}_{2}-\mathrm{Fe}_{2} \mathrm{O}_{3}$ 系フラックスが良好である。

（参考文献）1）青木健郎，松尾亭：鉄と銅，吕(1982）S293，2）松尾亭, 池

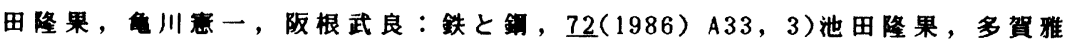
之，松尾亭：铁と銿， 65 (1979) S739，4）大沼敬明，住田則夫，桜谷敏和，

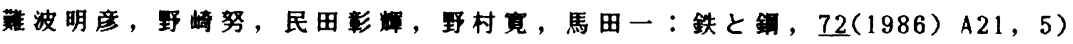

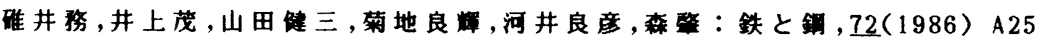

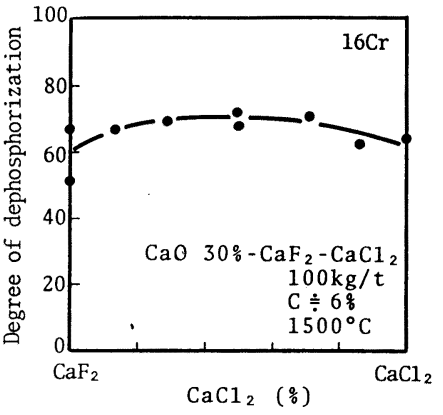

Fig.1 Effect of agent to get fluid

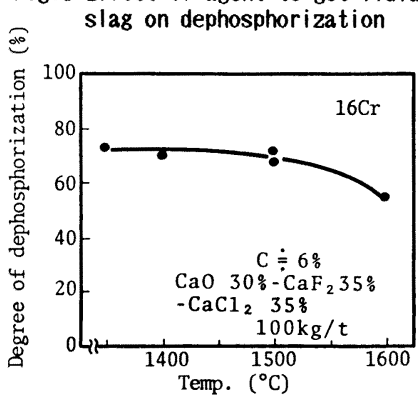

Fig.2 Effect of temperature on dephosphorization

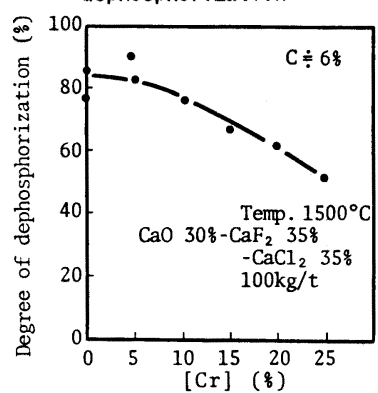

Fig. 3 Effect of chromium content on dephosphorization

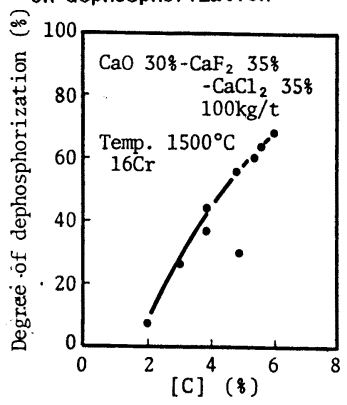

Fig.4 Effect of carbon content on dephosphorization 
'86-S 1004

（2１２） 10t試毁転炉におけ溶融還元後のステンレス粗溶湯の脱りん

（石灰系フラックスによる含クロム溶鉄の脱りん法の開発 第 2 報）

住友金属(侏) 総合技術研究所 丸川雄浄 姉崎正治 $\bigcirc$ 平田武行 和歌山 製鉄所 石川 稔

1. 緒言

クロム鉱石の溶酸還元によるステンレス鋼の溶製法を開発中であるが、年実用上の問題の一つに、成品 りん濃度の調整がある。低りん化の手段としては、溶融還元時に脱りん溶鉄，低りんコークスを使用す ることが一般的であるが、低りん化の保証のためには、溶融還元後にも脱りん手段が必要である。

2. 実験方法

前報 ${ }^{(2)}$ の結果をべースに、10 t 試験転炉を用いて実験を行なった。脱りん対象は溶䬌還元実験後の 炭素飽和溶湯（ $\mathrm{C} \fallingdotseq 6.5 \%, \mathrm{Cr} \fallingdotseq 20 \%)$ であるが、一部は粗脱炭後に脱りんフラックスを添加した。 脱りん剂は安価な $\mathrm{CaO}-\mathrm{CaF}_{2}$ 系をべースに選択し、一部には $\mathrm{CaCl}_{2}$ 子配合した。酸化剂はスラグ中に存 在する $(\mathrm{T}-\mathrm{Cr}),(\mathrm{T}-\mathrm{Fe})$ の活か、上吹酸素, 鉄鉱石である。固型物は全て炬上から分投し、底吹がス 覞拌によって反応を促進した。

3. 実験結果

(1) 脱りん処理状況

フラックス $33 \sim 100 \mathrm{Kg} / \mathrm{t}$ を 5 ～ 10 分間で分投 すると、フレームは若干出たが処理はスムーズであっ た。Fig 1 は $\mathrm{CaO}-\mathrm{CaF}_{2}-\mathrm{CaCl}_{2}-\mathrm{Fe}_{2} \mathrm{O}_{3}$ 系フラック スを $100 \mathrm{Kg} / \mathrm{t}$ 添加した結果で、10分間で $70 \%$ の脱 りん率を得た。この間、 $\mathrm{C} \%, \mathrm{Cr} \%$ 変化しなかった。 (2) $\mathrm{C} \%$ 影響

F i g 2 に従来 $\mathrm{CaO}$ 系で行われた大規模実験 ${ }^{(3)}$ (4) を含 めて、脱りん率に及㴗すフラックス原単位, C\%の影 響を示した。ルッボ実験においては一般にC％の影響 が強く認められ、(2)(3)今回のデ-ー夕女同様であった。

(3) フラックス組成の影響

スラグの融点は $\mathrm{CaO}-\mathrm{CaF}_{2}$ 系に $\mathrm{CaCl}_{2}$ を添加する方 が低下でをる。しかし本脱りんは $1500{ }^{\circ} \mathrm{C}$ 前後で行 われるため、 $\mathrm{CaO}-\mathrm{CaF}_{2}$ 系ですスラグの流動性は良好 である。 $50 \mathrm{~K} / \mathrm{t}$ の添加では脱りん率す $\mathrm{CaCl}_{2}$ を含む 場合と差がない。従って $\mathrm{P} \%$ 外れの救済を目的とする 軽脱りんでは $\mathrm{CaO}-\mathrm{CaF}_{2}$ 系で十分である。低りんステ ンレスを目的とする脱りん率 $50 \%$ 以上の本格処理で は、 $\mathrm{CaO}-\mathrm{CaF}_{2}-\mathrm{CaCl}_{2}$ 系が脱りん鼡として適当である。

\section{4. 結 言}

溶融還元後のステンレス粗溶湯に $\mathrm{CaO}$ 系フラックス を添加し、十分に脱りんでをることが確認できた。 (1)丸川, 平田ら：鉄と鋼 71 ( $\left.\begin{array}{llll}1 & 9 & 8 & 5\end{array}\right) \mathrm{S} 928$

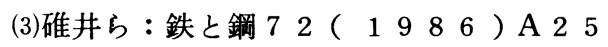

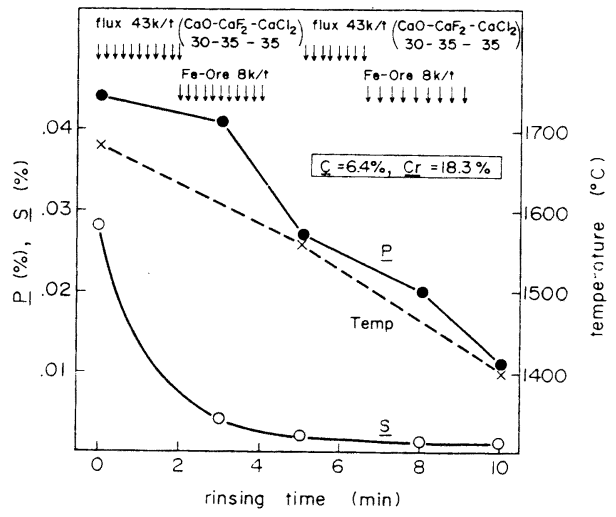

Fig.l Changes in $\underline{P}(\%), \underline{S}(\%)$ and temperature during the rinsing time with flux addition

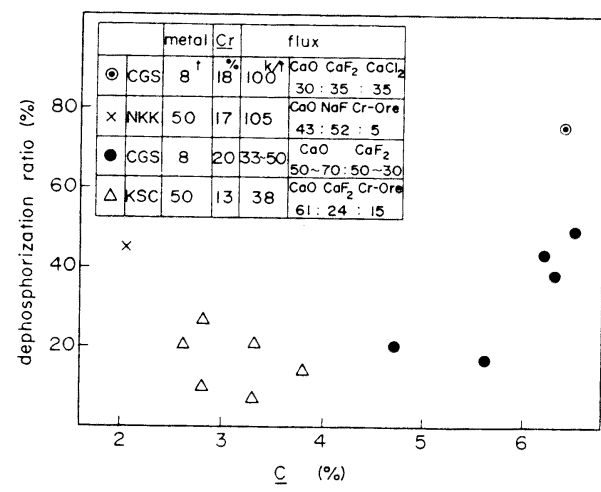

Fig.2 Effect of carbon content on the dephosphorization ratio

(2)松尾：第 112 回講演大会発表予定

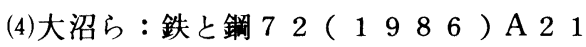




\section{(転炉内二次燃焼技術の開発 一 第 1 報)}

川崎製敇島製鉄所 ○亭柴信元 小島信司 吉川文明

新良正典武英雄楿林三

1. 緒言 転帅内熟補償の二次燃焼技術に関し、燃焼率と溶鋼への着熱率をより向上するための二次然焼用酸 素唄流を得るランスノズルを開発したので報告する。

2. ランスノズルの備えるべき条件

転㦿上吹きランスの二次燃焼に必要な機能は、

(1) 二次然焼炎が転炉壁やランスチップを損傷しない。

（2）燃焼熱は主にスラグを介して溶鋼に伀達すると考えられる ので燃焼域は烦内スラグ流域に形成する。

（3）二次燃焼はランスノズルからの酸素啫流と灯内の一酸化炭 素のガス流の衝突による拡散燃焼と推察され、燃焼域では酸 素噴流を火炎卮幡速度以下にする。

実験によればノズルからの噴流形状はFig.1に従うから吹錬 時のランス高さを維持して前記二次燃焼条件を満足するには， ズル出口の啫流速度を亜音速域に制御することが条件となる。

$\frac{3 . \text { ランスノズのプロフィール }}{\text { 従来二次燃焼ノズルはトレートまたはラバールが用いられ }}$ ており、数 $\mathrm{Kg} / \mathrm{cm}^{2}$ 以上の内区では㵒流初速は音速または超音速 となり前記条件を満さない。しかしFig. 2 に示すような急拡大 管ノズルを用いるとその断面積比によって噴流初速を要音速域 で任意に変えられる。すなわち、Fig.2においてA。に充分な民 力と流量が確保されれば、

$$
\begin{array}{lll}
\rho_{0} / \rho_{1}=\{(\kappa+1) / 2\}^{(1 / \kappa-1)} & \text {-(1) } & (\kappa: \text { 比熱比) } \\
\mathrm{C}_{0} / \mathrm{V}_{1}=(\kappa-1) / 2 & \text {-(2) } & \left(\mathrm{C}_{0}: \text { 音速 }\right) \\
\rho_{1} \mathrm{~V}_{1} \mathrm{~A}_{1}=\rho_{2} \mathrm{~V}_{2} \mathrm{~A}_{2} & \text {-(3) } &
\end{array}
$$

(1)(2)(3)より、 $\mathrm{V}_{2}=\frac{\rho_{0}}{\rho_{2}}\left(\frac{2}{\kappa+1}\right)^{1 / 2(\kappa+1)} \cdot \frac{\mathrm{A}_{2}}{\mathrm{~A}_{1}} \cdot \mathrm{C}_{0}$

で求められる。上式による噴流の初速值は実験でその一致を確 認した。したがって必要流量により入口面積を、必要㵒流初速 により出口面積を決めれば所要の二次燃焼域が形成できる。

Fig. 3 にランス内压と二次燃焼用酸素流量の関係を示す。

4. 結言 転开上吹きランスの二次燃焼用として急拡大管ノス ルを用いるとその断面積比によってノズ出口の嘖流初速を亚 音速域で任意に制御でき第 2 報のような良好な燃焼状態と溶鋼 への着熱がはかれることがわかった。

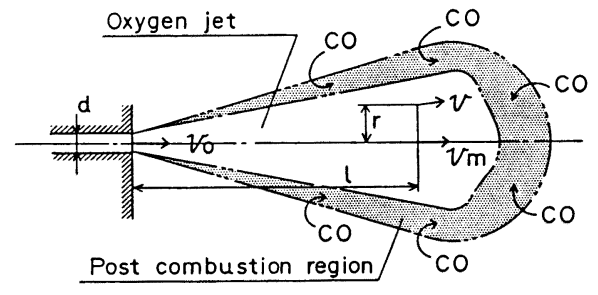

$$
\begin{gathered}
(V 0 / V m)=a(1 / d)+b \\
(V / V m)=\exp \left[-k(r / l)^{2}\right] \\
a, b, k, \text { constant }
\end{gathered}
$$

Fig. 1 General conception of post combustion flame

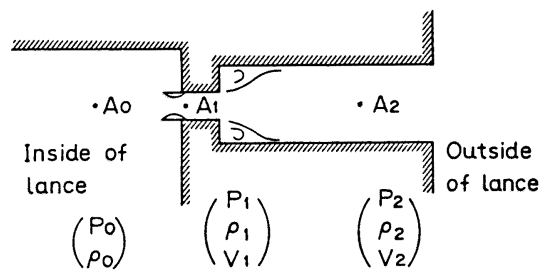

$P$ (pressure) $\rho$ (dencity) $V$ (velocity) $A$ (sectional area of nozzle)

Fig. 2 Schematic diagram of post combustion nozzle

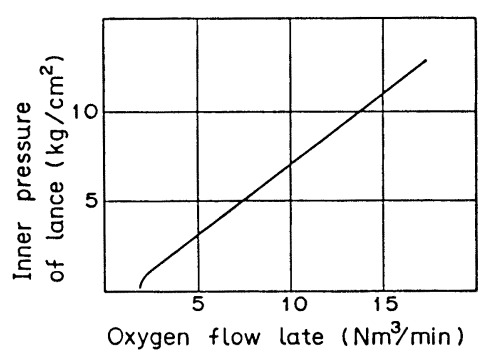

Fig. 3 Relation between oxygen flow rate and inner pressure of lance

<参考文献 $>$

1)奥田ら：鉄と鋼，71(1985)4,S186,

2) 岩本：(共立) 压縮性流体力学 
' $86-\mathrm{S} 1006$

(214) 上底吹転炉における二次燃焼技術の開発

(転炉内二次燃焼技術の開発一第2 報)

川崎製鉄侏) 水島製鉄所 ○新良正典武英雄高柴信元

吉川文明

1. 緒言 スクラップ価格の低下，溶鉄予備処理銑の吹鍊など、将来の主原料事情を考應すると転炉内におけ る熱補償は重要な技術である。熱補償のうち転炬内での C O ガス二次燃焼増大法は、コークス添加に比べて $\mathrm{S}$ による污染がなく低硫鋼には有利な熱補償技術である。今回、当所の $180 \mathrm{t}$ 上底吹き転炉（以下 L D - K G C ） において、特殊形状ランスチップを用い、炉内二次燃焼促進実験を行なったのでその結果について報告する。 2. 実験方法

本実験で使用したランスチップはサブホールは有するが酸素流路 の中にメイン吹鍊酸素流路とは別に急抾大管ノズルを有するサブホ ール用ガス流路を設けたランスである。

Table 1 にランス仕様を示す。また、Table 2 に実験条件を示す。

\section{3. 実験結果}

\section{(1) 二次燃焼率}

1 ヒ一トの平均二次燃焼率は、Fig.1 亿示すように以前報告した K - B O P の場合に比べたランス高さ増大による増加率は小さいが 2 次燃焼率は高くなっている。

(2) 着熱効率

着熱効率 $\left(\mathrm{CO}+1 / 2 \mathrm{O}_{2}=\mathrm{C}\right.$ Oによる発熱量に対する溶鋼潜熱増 分の割合)は、Fig. 2 に示すようにランス高さによる差は見られず 約 $60 \%$ である。本実験ランスの使用により通常に比較してスクラッ プ比を䄪 $6 \%$ 増大可能である。

（3）冶金特性

Fig.3 吹止〔C〕と（ T・Fe ) の関係を示すが、本実験ランスに よりランス高さを大きくした吹鍊においても底吹流量の確保により 通常吹鍊との差はみられない。

\section{4. 結言}

L D - K G C において特殊形状のランスチップを使用した 2 次 燃焼促進用ランスを開発し、熱補償に対して有効な技術である事 を確認した。また、二次燃焼用ランス使用 時の着熱効率および冶金特性についても明 らかにした。 <参考文献 $>$

1）高柴ら：本大会発表予定

2）奥田ら：鉄と鋼, 71 (1985) 4, S 186 竎

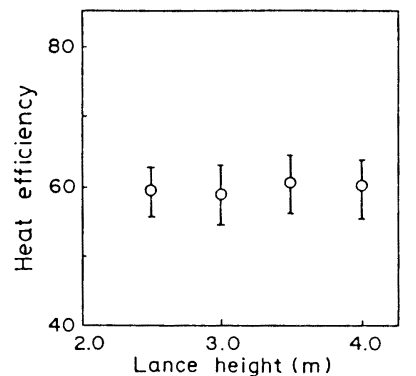

Fig. 2 Relation between lance height and heat transfer ratio to the melt
Table 1 Specification of P.C lance

\begin{tabular}{|c|c|c|}
\hline & Main & P.C \\
\hline Holes & 4 & 4 \\
\hline Nozzle type & laval nozzle & enlarge nozzle \\
\hline Jet angle & $12^{\circ}$ & $25^{\circ}$ \\
\hline $\mathrm{FO}_{2} / \mathrm{Fo}_{2}-\mathrm{ToT}$ & $80 \%$ & $20 \%$ \\
\hline
\end{tabular}

Table 2 Test condition

\begin{tabular}{|l|c|}
\hline Lance height & $2.5 \sim 4.0 \mathrm{~m}$ \\
\hline Bottom blowing & $0.15 \sim 0.20 \mathrm{Nm} / \mathrm{min} \cdot \mathrm{t}$ \\
\hline Top blowing & $2.5 \sim 3.1 \mathrm{Nm} / \mathrm{min} \cdot \mathrm{t}$ \\
\hline
\end{tabular}

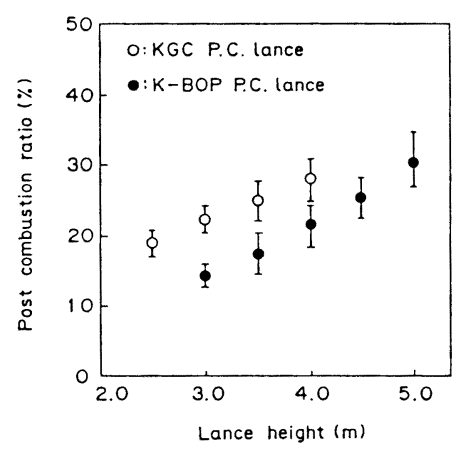

Fig. 1 Dependence of P.C. ratio on the lance height

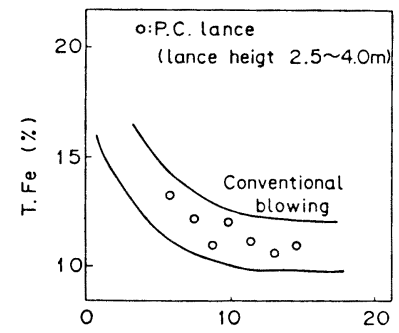

(C) $\left(\times 10^{-2} \%\right)$

Fig. 3 Comparison of (T. Fe) at blow end 


\section{（215）＼cjkstart炉内二次燃焼機檴の考富 \\ ( 二次燃焼法の開発 第 4 報 )}

住友金属工業(和和歌山製鉄所 $○$ 石川 稔 加藤木健 総合技術研究所鈴木 豊 平田武行 城田良康 姉崎正治

\section{1. 緒 言}

前報 ${ }^{1)}$ ておいて二次然焼が酸素ジェット表面、および内部で起てっているとと、火点での $\mathrm{CO} 2$ 還元反 応が二次燃焼此率に重要な影響を持っているとと等をホットモデルでのコークス燃焼試験で明らかにし た。これらの知見をもとに本報では二次燃焼機構につき更に考察し、その数式モデルを検討した。

2. 二次燃焼機樓 (F ig.1)

\section{3. 数式モデル}

(1)上吹ジェットによる雲囲気同伴

上吹ジェットによる炣内䨌囲気ガスの巻き込み量を定量化するため 高温然焼フレーム $\left(1200^{\circ} \mathrm{C}\right)$ への空気巻き込み量を測定し、次式を得た。

$$
\frac{\mathrm{Ge}}{\mathrm{Go}}=0.18\left(\frac{\mathrm{L}}{\mathrm{d}}\right)-1-(1) \quad \begin{aligned}
& \mathrm{Go}: \mathrm{O}_{2} \text { 質量流量 } \\
& \mathrm{Ge}: \text { 同伴ガス質量流量 }
\end{aligned}
$$

(2) 火点での $\mathrm{CO} 2$ 還元反応

上吹ジェットは(1)式に従って雰囲気ガスを同伴し C O 然焼反応 により高温の ( $\left.\mathrm{CO}-\mathrm{CO}_{2}-\mathrm{O}_{2}\right)$ フレームを形成し火点においてコー

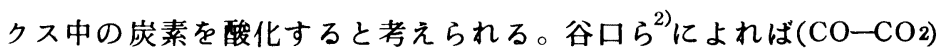
噴流によるグラファイトの酸化速度は気相内物質移動で律速される。す

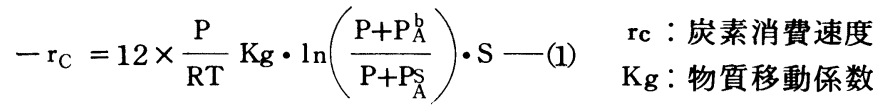

$\mathrm{P}_{\AA}^{\natural}, \mathrm{P} \AA ：$ 噴流内部および炭材界面での $\mathrm{CO} 2$ 分圧

$\mathrm{P}$ ：全圧, $\mathrm{S}$ ：反応界面積

4. 数式モデルによるホットモデルデータの解析

(1) 火点直前での上吹ジェットのガス組成、温度の推定例。

\begin{tabular}{|l|c|c|c|c|}
\hline & $\left(\% \mathrm{CO}_{2}\right)$ & $(\% \mathrm{CO})$ & $\left(\% \mathrm{O}_{2}\right)$ & Temp $\left({ }^{\circ} \mathrm{C}\right)$ \\
\hline At mospheric gas & 44.6 & 55.4 & 0 & 1265 \\
\hline Upper bl owing jet & 59.7 & 34.4 & 5.9 & 2465 \\
\hline
\end{tabular}

(2)上吹条件による炭素酸化速度の変化

(2)式において炭素酸化速度（ $\mathrm{CO} 2$ 還元速度）を決定するのは実 質的にKg・S である。コークス燃姾試恡におけるKg・S は無次元 ンス高さ $\mathrm{L} / \mathrm{d}$, 上吹ジェットのRe数により変化し (F i g.2,3)、そ の傾向は、ソフトブロー化により転炻の二次然焼比率が上昇する という従来の知見と対応している。
[参考文献)
1）石川ら：鉄と鋼72(1986), S181
2）谷口ら：鉄と鉷63(1977)，P1071

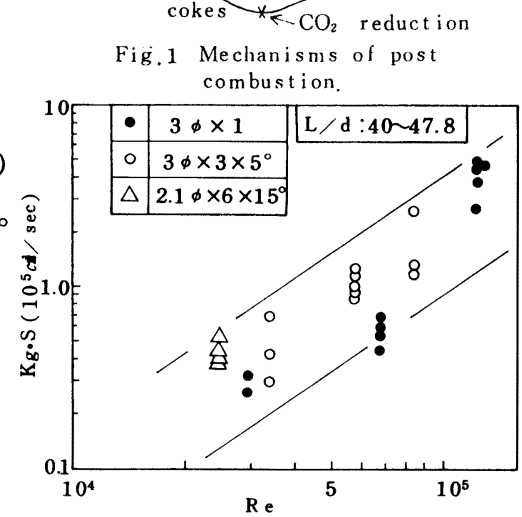

Fig. 2 Effect of Reynolds number on $\mathrm{Kg} \cdot \mathrm{S}$

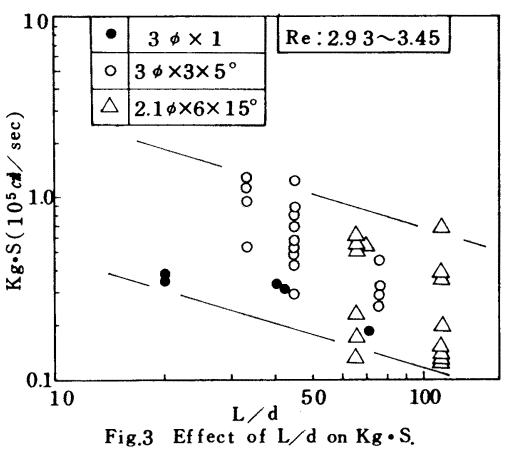


' $86-\mathrm{S} 1008$

\section{（2１6）転灯ー連鋳エ程による高炭秦クロム軸受鋼の製造}

$\begin{array}{cccc}\text { 川崎製鉄㧣）水島製鉄所 } & \text { ○名村夏樹 反町健一 } \\ \text { 鉄鋼研究所 前田端夫 }\end{array}$

1. 緒言 軸受用素材（ＳＵ J 2 鎆）は、電気炉一造塊工程で製造されることが一般的であるが、連鋳材の均 一性に着目し、不純物元素の低減の点から、転㦿一連鋳工程を採用して良好な製品成績が得られたので報告す る。

2. 高炭素軸受鋼の要求品質特性 軸受鋼で最も重要な特性は、疲労寿命が長いことである。亀裂の起点は、 酸化物系介在物や介在物周辺に拡散一析出した板状炭化物にあると報告 ${ }^{1 ｝ \text { されている。連鋳法は造塊法に比較 }$ して、成分の均一性の点で優れているが、中心部の炭素偏析による寿命低下が艌念された。そこで連鋳化に際 し、酸化物系介在物の低隇に特に配虑した。

3. 軸受鋼の極低酸素化に関する溶製，鋳造方法の検討

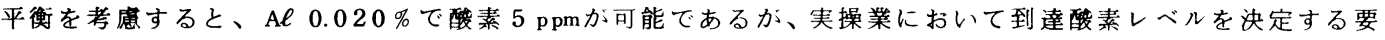
因は、脱酸速度の向上と再酸化防止に大別される。各項目ごとの検討を以下に示す。

(1) 脱酸速度の向上……ㄱ..ラックスインジェクションと R H 脱ガスによる強㨨抖取鍋精鍊の実施。

(2) 再酸化防止

(1)取鍋スラグ中の Fe O による酸化……… スラグ中の F e O を $0.1 \%$ 以下とする。

(2)取鍋スラグからの $\mathrm{Si} \mathrm{O}_{2}$ の解離……… $\mathrm{CaO}-\mathrm{SiO}_{2}-\mathrm{A \ell}_{2} \mathrm{O}_{3}$ 系スラグ中の $\mathrm{Si}_{2}$ 活量を最小とす るフラックス成分の選択

(3) 取鍋耐火物からの $\mathrm{S}$ i O 2 の解離 高アルミナ質酎火物の採用

以上の検討をもとに軸受鋼の溶製, 鋏造工程の要点を以下の通り 决定した。

(1) 転厌 …………脱燐予備処理溶銑を使用し、L D - K G C 炉に よる低酸素出鎘。

(2) F. I 強靦挥によるスラグ中 F e O の低减およびスラ グ塩基度コントロールフラックス処理。

（3） R H 脱ガス……高真空度, 強摜拌処理による脱酸生成物の浮上 分離。

(4) C C ……….... 完全 A r シールによる断気鋳造。

大断面ブルーム ( $400 m m \times 560 m m)$ と低温鋳造

$\left(\triangle \mathrm{T} \leqq 20^{\circ} \mathrm{C}\right)$ および電磁鯢汼の適用による中 心偏析の低减。

\section{4. 軸受鋼の製造結果}

上記方法に基つき、昭和 60 年 8 月より軸受鋼の連鋳化を図った。 その結果、Fig. 1 に示すように到達酸素値 $\bar{x}=8.8 \mathrm{ppm}$ を達成し、 従来法に比較して約 $4 \mathrm{ppm}$ の酸素低隇となった。このため、Fig. 2 に示すように疲労寿命が約 $75 \%$ 向上する良好な成績が得られた。 参考文献
1）上杉年一：鉄と鋼，71（1985）14，P 1631
2）山崎ら：鉄と鋼， 72 (1986)4, S. 195

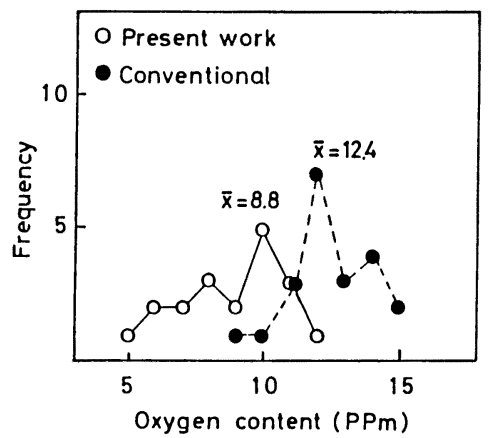

Fig.1 Oxygen distribution of SUJ2

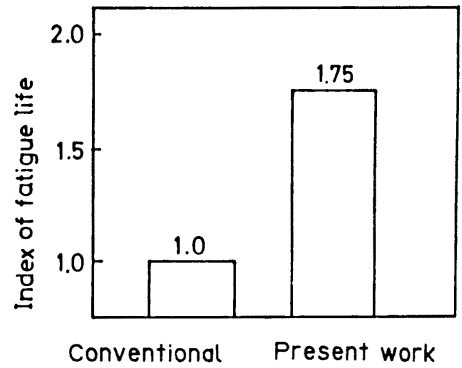

Fig. 2 Comparison of fatigue life between present work and conventional work 
$13 \% \mathrm{Cr}$ 鋼の連続鋳造化

' $86-\mathrm{S} 1009$

\begin{tabular}{|c|c|c|c|c|}
\hline 日本鋼管侏 & 京浜製鉄所 & 山上 諄 & 天満英昭 & 館山 \\
\hline & & 鈴木克紀 & ○久保 孝 & \\
\hline
\end{tabular}

物吾嬬製鋼所 仙台製造所菅原功夫

\section{1. 緒 $\overline{\overline{\bar{a}}}$}

耐サワーガス油井管用 $13 \% \mathrm{Cr}$ 鋼を連続鉡造する場合、鋳片 センターポロシティーの発生が著しく，製管時の内面不良率増加 につながるため連鋳化が困難であった。当所では, 垂直型大 断面ブルーム連鋳機を使用し，低温鋳造をはじめとする鋳造技 術の改善と分塊王延技術により，ビレットのセンターポロシテ ィを大巾に低減するととが可能になった。

\section{2. センターポロシティーの発生機構}

Fig. 1 亿センターポロシティの発生機構を示した。13 Cr 鉘 汢その物性上, 一般炭素鋼と比較して高温域における熱伝導度 が大さいとと、Cr 鋼の中では最も粘性の高い領域にあるなどの 特徴がある。乙のため凝固先端におけるブリッジング現象と給 湯不足が併発し, さらに凝固完了直後の軸心部の急激な温度低 下による引張応力が内部割れを含むセンターポロシティの拡大 在助長すると考えられる。

\section{3. 製造上の改善点}

a）鋳造技術鋳造時のタンディッシュ内溶鋼過熱度の目 標を $30^{\circ} \mathrm{C}$ 以下としモールド内電磁擋拌を行い微細等軸晶生成を 促進した。むた, 凝固末期電磁擋拌によって等軸晶充填効果を 增大させマクロポロシティーの分散化を図ると同時に, 比水量 を $0.24 \ell / \mathrm{kg}$ ( sleel) 飞抑え, 七ンターポロシティーの拡大, 並びにこれに伴なら内部割れを抑制した。

b) 压延技術 Fig.2亿強压下圧延のスケシュールを示し た。従来の分塊粗角压延方法死改良し、厚み方向の初期および 仕上げフラットパスの 1 パス当りの压下量を $40 \sim 50 \mathrm{~mm} / \mathrm{pass}$ から 85〜105 m/passに変更した。また, 巾方向のエッジン グパス压下量は $40 \sim 60 \mathrm{~mm} / \mathrm{pass}$ としセンターポロシティーの 圧着効果向上と外面性状の改善を図った。

\section{4. 結 言}

低温鋳造技術ならびに強压下圧延技術の確立によってビレッ 卜軸心性状は著しく向上し、マンネスマン製管時における内外 面不良率も造塊材と医同程度に良好であり, 管外面性状は黒 皮材でも造塊材に比べ良好な結果が得られた。

1) 石坂ら：鉄と鋼，70(1984) S 277
Table 1. Typical composition of $13 \% \mathrm{Cr}$ steel

\begin{tabular}{|c|c|c|c|c|c|}
\hline $\mathrm{C}$ & $\mathrm{Si}$ & $\mathrm{Mn}$ & $\mathrm{P}$ & $\mathrm{S}$ & $\mathrm{Cr}$ \\
\hline 0.20 & 0.26 & 0.49 & 0.017 & 0.001 & 12.80 \\
\hline
\end{tabular}

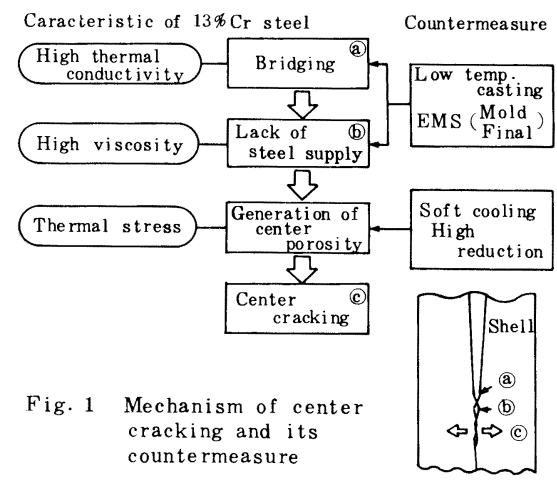

\begin{tabular}{|c|c|c|}
\hline & High reduction & Convent inal \\
\hline $\begin{array}{l}\text { First } \\
\quad \text { pass }\end{array}$ & 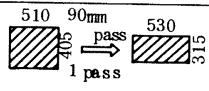 & 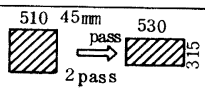 \\
\hline Edging & 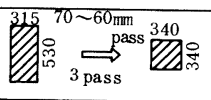 & 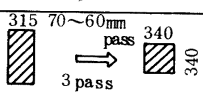 \\
\hline $\begin{array}{r}\text { Finishing } \\
\text { pass }\end{array}$ & 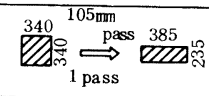 & $\square_{1 \text { pass }}^{340} \stackrel{40 \mathrm{~mm}}{\stackrel{\text { pass }}{\Rightarrow}}$ \\
\hline Final ${ }_{\text {Size }}$ & $235 \times 385^{\mathrm{mm}}$ & $300 \times 360 \mathrm{~mm}$ \\
\hline
\end{tabular}

Fig. 2 Process of high reduction

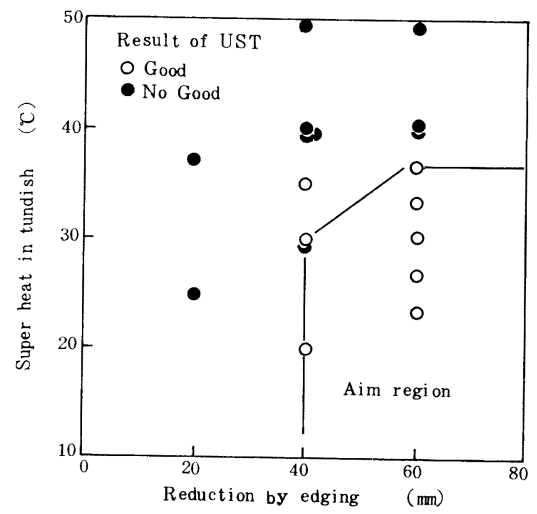

Fig. 3 Influence of U.S.T. inspection for operating condition 
'86-- S 1010

\section{（2１８） 大断面ブルームCCによるPb 快削鋼の製造}

新日本製鐵(侏) 室蘭製鐵所 ○石山和雄、鈴木功夫、吉田正志

中央研究本部 前出弘文、磯部浩一

\section{1. 緒 言}

従来、低炭 $\mathrm{S}-\mathrm{Pb}$ 快削鋼は造塊注入により製造されていたが、連鋳材の特徵である均質性を生かす心゙ く、当所では、昭和 59 年 1 月より $350 \times 560 \mathrm{~mm}$ の大断面ブルーム鋳造により製造を開始した。鋳造技 術面では、1)耐溶損性耐火物の使用、2）高粘性パウダーの使用、3 ) 鋳片冷却水の低比水量化を実施 した。品質面では、造塊材に比較して Pb分布は均一であり、更に鋳片冷却水量の低減によって MnSが大 型化し造塊材と同等の被削性が得られた。

\section{2. 設備概要}

当所スラブ、ブルーム兼用連鋳機の主な緒言をTable 1 に示す。

Table 1 Basic Specifications of Continuous Casting Facility

\begin{tabular}{|c|l|}
\hline It em & \multicolumn{1}{|c|}{ Basic Specifications. } \\
\hline $\begin{array}{l}\text { Continuous casting } \\
\text { machine }\end{array}$ & Slab - bloom continuous caster \\
\hline Capacity & $\begin{array}{l}152,000 \text { tons } / \text { month } \text { SL }: 61.000 \text { tons } / \text { month, } \\
\text { BL }: 91,000 \text { tons } / \text { month }\end{array}$ \\
\hline Casting size & $\begin{array}{l}\text { SL }: 250 \times 600 \sim 1,300 \times 4,000 \sim 10.000 \mathrm{~mm} \\
\text { BL }: 350 \times 560 \times 4,000 \sim 6.800 \mathrm{~mm}\end{array}$ \\
\hline Casting speed & BL $: 1.0 \mathrm{~m} /$ minute maximum m \\
\hline
\end{tabular}

\section{3. 鋳造結果}

低炭 S- Pb快削鋼の成分をTable 2 に示す。 $\mathrm{Al}$ フリーで、かつSiレスの

Table 2 Chemical composition of free-cutting cabon-steels

\begin{tabular}{|c|c|c|c|c|c|c|c|}
\hline & C & S I & M n & P & S & P b & T 0 \\
\hline SUM22L & $<0.13$ & $<0.10$ & $0.76 / 1.00$ & $0.07 / 0.12$ & $0.24 / 0.33$ & $0.15 / 0.35$ & $<250$ \\
\hline SUM23L & $<0.09$ & $<0.10$ & $0.04 / 1.05$ & $0.04 / 0.09$ & $0.26 / 0.35$ & $0.15 / 0.35$ & $<250$ \\
\hline
\end{tabular}

ために、T Oが高いのが特徴である。そのために耐火物は耐溶損性の 高い $\mathrm{MgO}$ 系及び $\mathrm{ZrO}_{2}$ 系を採用した。又、Fig. 1 亿示すようにパウダー中 への $\mathrm{MnO}$ ピックアップによりパウダー粘性が低下するため、高粘性パウ ダーを使用し操業の安定化をはかった。

\section{4. 品質結果}

Fig. 2 亿連鋳片と鋼塊の各部位でのPb濃度分布を示す。連鋳材のPb濃度 分布は均一で鋼塊で見られるような Top片への $\mathrm{Pb}$ の偏析は見られない。

Fig. 3 亿鋳片冷却水量と $\mathrm{MnS}$ の粒子サイズの関係を示す。冷却水量を減 ずると MnS 粒子サイズが大きくなるととがわかる。これは鋳片の緩冷化によ り凝固速度が低下し、2 次デンドライトアーム間隔が大きくなる結果、MnS 粒子が大型化するものと推論される。一般に MnSが大型化するほど、被削性.

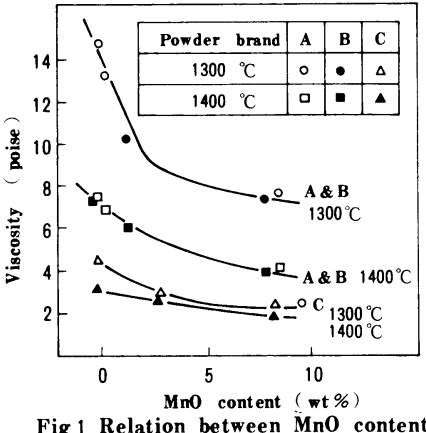

Fig I Relation between Mn0 content and powder viscosity

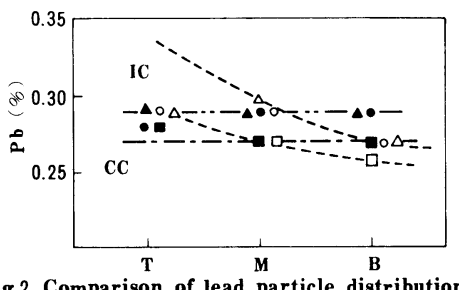

Fig 2 Comparison of lead particle distribution between $\mathrm{CC}$ bloom and ingot

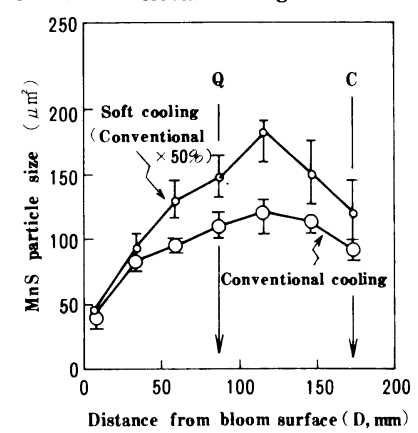

Fig 3 Relation between $S$ and distance from bloom surface が向上する事が知られており、当所の連鋳材の被削性は造塊材と闰等との結果を得ている。

\section{5. 結 言}

低炭 $\mathrm{S}-\mathrm{Pb}$ 快削鋼を連鋳により製造する技術を確立し、均質で、かつ造塊材と同等の被削性を有する 快削鋼の製造が可能となった。 
(219) 連鋳材鉛快削䤡の品質について

住友金属工業森小倉製鉄所 山田 昇、瀧 正彦 ○条村和成、神屋幸一

1. 緒 言

総合技術研究所 条䤡研究室 奥山貞敏

近年、鉛快削銅の需要は自動車用をはじめ增加傾向にある。また、品質の均一性において優位な連続 鋳造法による製造が採用されつつある。今回、機械構造用炭素鋼、及び低合金鋼に鉛添加した鋼種のC C 錆込試娩を実施し、鉛粒の分布状況、切削性等の品質を調查した。結果を報告する。

2 . 調查力法

取銷内溶䤡段階で鉛添加を行った後、当所の $300 \times 400 \mathrm{~mm}$ ブルーム連鋳機にて鋳造したブルーム鋳

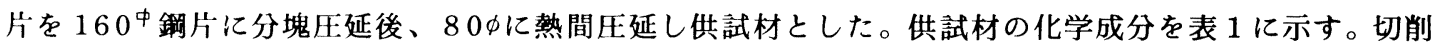
性の調䍒として、旋削試験は $80 \phi$ 圧延材を、また穿孔試験については 160 鋼片を $35 \mathrm{~mm}$ 厚にスライス したものを用い、S4 5C-Pbは焼ならし（820 C $\times 1.5 \mathrm{Hr} \rightarrow \mathrm{A} . \mathrm{C}) を 、 S C M 415-\mathrm{Pb}$ は、焼なまし(850 C $\times 1.5 \mathrm{Hr} \rightarrow$ F.C ) を施した後試験をした。

\section{3 . 調査結果}

Fig. 1亿 160 中鎆片における $\mathrm{Pb}$ 粒の分布状 況を示す。図より鉛快削鋼 C C 材の P b 粒は微 Table. 1 Chemical composition of Pb containing steels (wt \%)
\begin{tabular}{|c|c|c|c|c|c|c|c|c|c|}
\hline & $\mathrm{C}$ & $\mathrm{Si}$ & $\mathrm{Mn}$ & $\mathrm{P}$ & $\mathrm{S}$ & $\mathrm{Cr}$ & $\mathrm{Mo}$ & $\mathrm{Sol} \mathrm{Al}$ & $\mathrm{Pb}$ \\
\hline SCM-415Pb & 0.16 & 0.20 & 0.69 & 0.021 & 0.026 & 1.02 & 0.16 & 0.032 & 0.16 \\
\hline $\mathrm{S} 45 \mathrm{C}-\mathrm{Pb}$ & 0.45 & 0.22 & 0.72 & 0.018 & 0.024 & 0.11 & 0.01 & 0.036 & 0.18 \\
\hline
\end{tabular} 小であり、最大でも $20 \mu$ 以下であった。特に、表面近傍で は $5 \mu$ 以下の敞粒の比率が多い。Fig 2 亿 $45 \mathrm{C}-\mathrm{Pb}$ の、 Fig 3 に SCM 4 15-Pb の旋削時の工具寿命 ( V-T曲線) を示す。フランク摩耗、クレーター摩耗いづれにおいても同 一溶製条件の造塊材と較べて同等の切削性能を有している。 また、ドリル寿命についても調䍒したが造塊材と同等もしく は若干短い程度であった。

\section{4. 結 言}

連鋳材鉛快削銅の品質調䍒の結果、 $\mathrm{Pb}$ 粒は 160 中鎆片で 調べた結果 $20 \mu$ 以下の微粒で均一に分散している。また、 切削性については同一溶製条件の造塊材と較へて遜色ないレ ベルであるてとが確認できた。
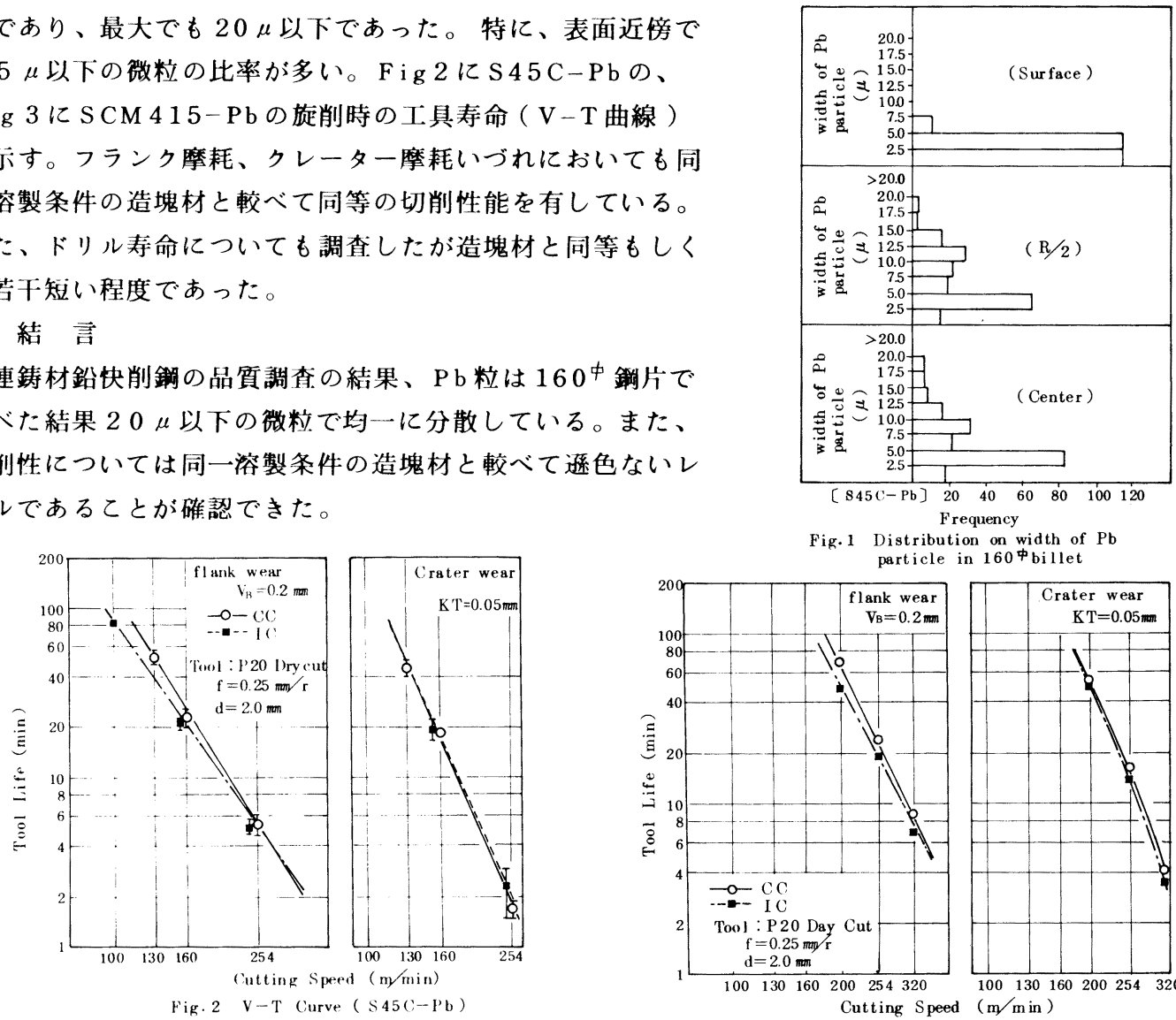

Fig. 1 Distribution on width of $\mathrm{Pb}$ particle in 160 中illet

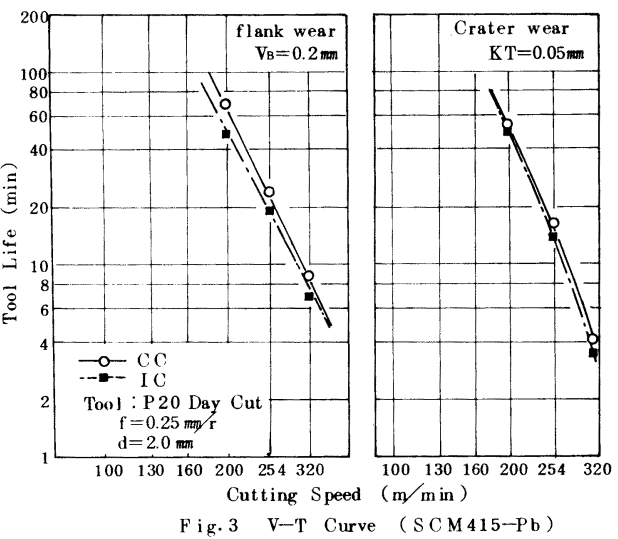


' $86-\mathrm{S} 1012$

\section{（220）鋳型内流動に関する水モデル実験 \\ （高速鋳造時における鋳型内湯面での溶銅流動制御ーI）}

日本鋼管 中央研 福山研 C手嶋俊雄 工博 北川 融

福山製鉄所舟之川洋 沖本一生丹村洋一近藤恒雄

1. 緒言連鋳々片の介在物は、鋼の溶製段階からタンディッシュにいたる諸対策により大幅に低減 した。したがって、2 $\mathrm{m} /$ 分を越える鋳造鋳片での介在物に関しては、鋳型内で発生するパウダー巻込 みが、問題となる可能性がある。従来よりパウダー巻込みと鋳型内湯面変動との関連はよく知られてい るが、今回、福山 5 号機の高速鋳造化に伴ない、鋳型内流動の水モデル专験を実施して、鋳型内湯面変 動量を操業諸因子(浸漬ノズル形状, 鋳造速度, 鋳造幅, ノズル内ガス吹込量, ノズル浸漬深さ等) で 整理し適正湯面変動を確保するための指標を得たので以下に報告する。

2. 実験方法 実験はフルード数近似にもとづき、央機 $1 / 3$ 縮尺モデルを用いて実施した。以下に央 験条件を示す。

。鋳片： $10 \mathrm{mR}$ 相当弯曲型, 垂直型の 2 種モデル

。鋳片サイズ：650〜3000 mm 幅相当

。鋳造速度：1.4 4.98 Ton /分相当

。吹込ガス流量（修正フルード数近似）：0〜20 $\mathrm{N} \ell /$ 分相当

。浸漬ノズル形状 : 逆 $\mathrm{Y}$ 型, プール型丸孔ノズル 実験は鋳型内流動を $\mathrm{A} \ell$ 粉トレーサーを用いビデオ収録 解析し Fig. 1 定義の湯面变動量測定值との関係在調べた。 3. 結果 (Fig. 2, Fig. 3 )

鋳型内湯面変動は、ノズルからの吐出流が短辺面に衝 突した後、メニスカスに向う溶鋼運動量と短辺メニスカ スからの衝突深さの逆数との積 (特性值 $\mathrm{F}$ と称する) で 評価できることがわかった。ここで重要な事は、浸漬， ズルからの吐出流は直進せずに、短辺に向うにしたがい 浮上するような曲率をもつ線上（吐出流軌跡）に沿って 進行する点である。よって同一浸漬ノズルの場合でも、 鋳片幅によって短辺への吐出流衝突角はまったく異なり、 また衝突深さも 1 次的には決らない。さらにこの吐出流 軌跡は、鋳造速度，ガス吹込量によっても変化する。し たがって鋳型内の湯面変動量を適正範囲 ${ }^{1)}$ に収めるには、 使用浸漬ノズルの吐出流軌跡とその流速変化を把握し、 鋳片幅，鋳造速度に応じたノズル角度を選定し、浸漬深 さガス吹込量をコントロールしていく必要がある。

4. 結言高速鋳造時における鋳型内の湯面変動量を 決定する操業諸因子を整理し、特性值 $\mathrm{F}$ 定義した。

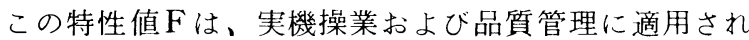
て、効果をあげている。

参考文献 1）小谷野, 丹村ら：本大会で発表予定

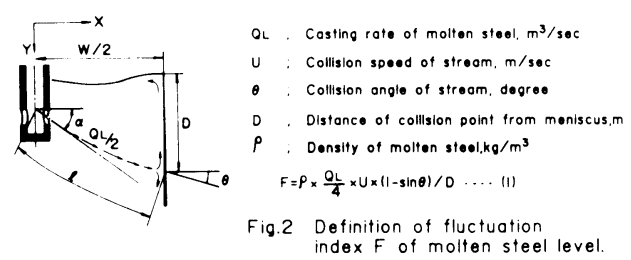

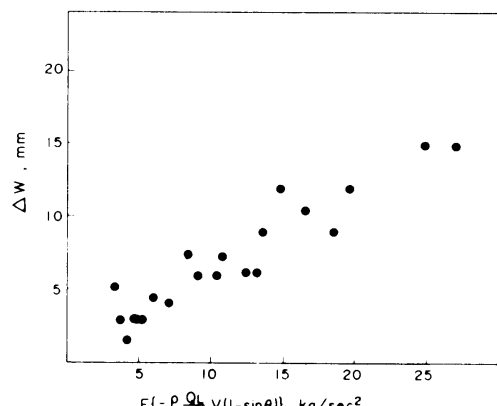

$F\left\{=\rho \frac{Q 1}{4} v(1-\sin \theta)\right\}, \mathrm{kg} / \mathrm{sec}^{2}$

Fig.3 Relationship between fluctuation index $F$ of molten steel level and the maximum of level fluctuation in C.C. mould 


\title{
（22」） 高速鋳造時における浸清ノズル形状の最適化 （高速鋳造時における鋳型内湯面での溶鋼流動制御－2）
}

\author{
日本鋼管侏 福山製鉄所 小谷野敬之 和田勉 $\bigcirc$ 丹村洋一 近藤恒雄 \\ 中央研 福山研 手嶋俊雄 工博 北川融
}

1. 緒言 高速鋳造時において, 浸漬ノズルからの溶鋼吐出量が大きい為に生じるモールド内の湯面変 動は，モールドパウダー巻き込み等品質欠陥の原因となりうる。そてで, 第 1 報 $^{1)}$ で示した如く水モデ ル実験結果から得られた特性值を基にして各操業条件に応じた最適浸漬ノズル形状及び他の操業条件を 選定し鋳造を行った結果，良好な成績が得られたので以下にその内容について報告する。

2. 結果及び考察図1亿示す如くスラブ巾，溶鋼吐出 量に関係なく同一,ズル形状にて鋳造を行った場合，吐 出量が多い（スラブウの広い）時に，品での表面欠陥 発生率が高くなっている。又, 吐出量が少ない狭巾の場 合も同様に欠陷の発生率が高くなっている。そとで，第 1 報に示した水モデル実験から得られた特性值 $\mathrm{F}$ を用い , 図 2 に示す如く操業条件の解析を行った。吐出量が大 きい場合, 特性值 Fが 5.0 以上の時に欠陷が集中してい る。乙れは, 短辺衝乫流が大きく湯面変動に伴うパウダ 一巻き込みに起因する久陷と考元られる。一方，吐出量 が少ない場合、特性值 Fが 3.0 以下の時に尔楩が集中し ており, 短辺衝突流に伴う上向きの運動量が小さい事に よるメ二スカス部の洗净効果不足, 及び熱供給不足によ るものと考えられる。

これらの問題を解決する為に, 特性値 $\mathrm{F}$ に影響を与え る各要因の改善, 適正化を行った。1つに, 浸漬ノズル の形状，角度の適正化として，広巾材に対し角度を大き くし湯面変動死抑制した。一方，狭巾材に対しては逆に 角度を小さくして上向き流の運動量増を図った。又，モ ールド内人吹込むアルゴンガス量は, 湯面変動の要因の 1つとなる為, 浸漬,ズル内壁へのアルミナ付着による 操業トラブル，及び，品質に悪影響を与えない範囲で, 抑制する事とした。その結果, 困 3 亿示す如く, 狭巾 ( $700 \mathrm{~mm})$ から広巾 $(1650 \mathrm{~mm})$ まで安定した品質を 得る事が可能となった。

3. 結言 高速鋳造における湯面変動の抑制, 及び, 狭 巾材等の溶鎆吐出量が少ない場合に生じるメニスカス部 の洗净効果, 熱供給不足を解決する為, 水モデル実験か

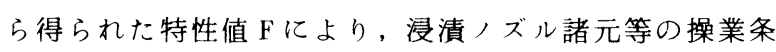
件を整理し，最適な操業が可能となった。

(参考文献)

1）手䳋ら：本講演大会発表予定

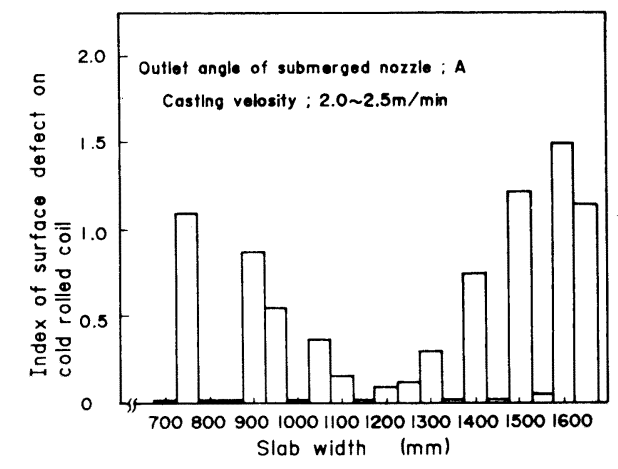

Fig.I Relation between slab width and index of surface defect on cold rolled coil.

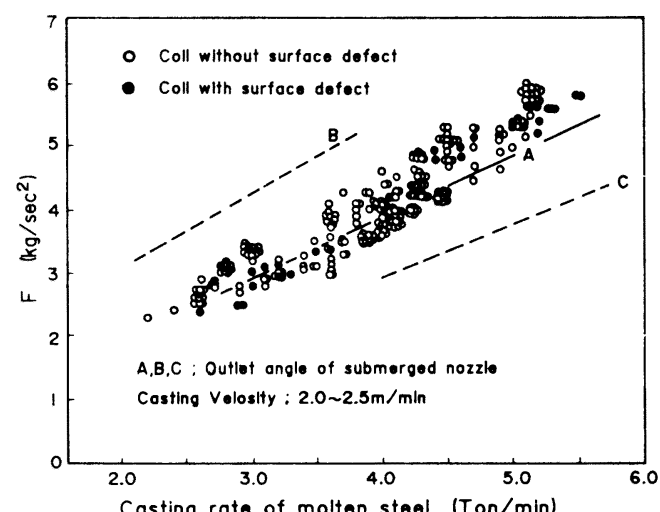

Fig.2 Relation between casting rate of molten steel and fluctuation index $F$.

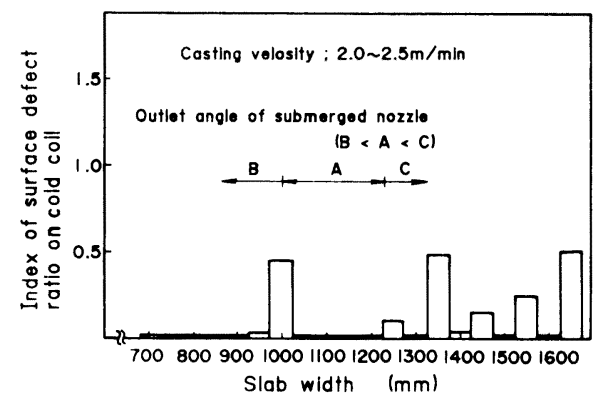

Fig.3 Relation between slab width and index of surface defect on cold rolled coil after improvement. 


\section{(222) 連鋳鋳型内電磁㩭拌技術の開発}

新日本製鐵(株)大分製鐵所 $○$ 白井登喜也，益守照道，仲 億, 常岡 聡 大分技研 三隅秀幸

\section{1. 緒 言}

高酸素領域で C O気泡の発生を抑え、低 A 1 鎆の連鋳化を目的として、大分 4 号連鋳機に高推力鋳型

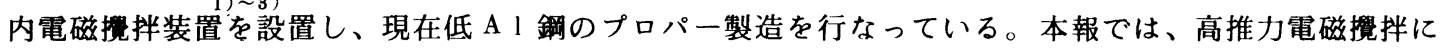
よる鋳片気泡発生の改善及び介在物低減効果について報告する。

\section{2. 高推力化}

気泡発生限界を著しく向上させるために、高推力電磁嬂拌 装置を開発した。その要点は、(1)ポールピッチアップ、(2)ヨ 一ク断面積の挔大、(3)銅板の薄肉化・低電気伝導化のための 銅板・S U S 爆着方式の改善である。その結果、推力は従来 の 2 倍にアップした。

\section{3. 気泡発生限界の改善}

Table 1 亿示す組成溶銅を高推力・従来推力・無拍拌のそ れぞれの条件下で鋳造し、鋳片表面気泡発生状況を調査した。 その結果を Fig. 1 亿示す。気泡発生限界sol.[A1]が、高推力 の場合、 $0.001 \%$ まで改善され、リムド・キャップド鋼にさ らに一歩近づき、完全時効型の材質確保が可能となった。

\section{4. 介在物低減効果}

低 [Al]鋼の介在物調査結果をFig.2亿示す。乙れは、表 層 $\mathrm{Al}_{2} \mathrm{O}_{3}$ クラスターによる製品品質異常率を擋拌の有無で比 較したものである。摜拌により、製品品質異常が皆無となっ た。これは、筧拌することで、ウォッシング効果が促進され た結果であると考えられる。

\section{5. 結 言}

(1)高推力鋳型内電磁䚁拌により、低 A 1 鎆の連鋳化が可能 となった。その気泡発生限界Sol.[A1]も、0.001\%まで改善 した。

(2)㩖拌によるウォッシング効果で、 $\mathrm{Al}_{2} \mathrm{O}_{3}$ クラスター起因 の品質異常が改善された。

\section{6. 参考文献}

1）竹内ら 鉄と銅, 66 (1980), S797

3）丹野ら鉄と鋼，68 (1982), S 267
Table. 1 Chemical compositions(\%)

\begin{tabular}{|c|c|c|c|c|c|c|}
\hline C & $\mathrm{Si}$ & $\mathrm{Mn}$ & $P$ & $\mathrm{~S}$ & sol Al & O \\
\hline $\begin{array}{r}.033 \\
.059\end{array}$ & Tr. & $\begin{array}{r}.22 \\
1 \\
.51\end{array}$ & $\begin{array}{l}.010 \\
.018 \\
.018\end{array}$ & $\begin{array}{l}.009 \\
.016\end{array}$ & $\begin{array}{r}\mathrm{Tr} . \\
.01\end{array}$ & $\begin{array}{l}.0009 \\
.0076\end{array}$ \\
\hline
\end{tabular}

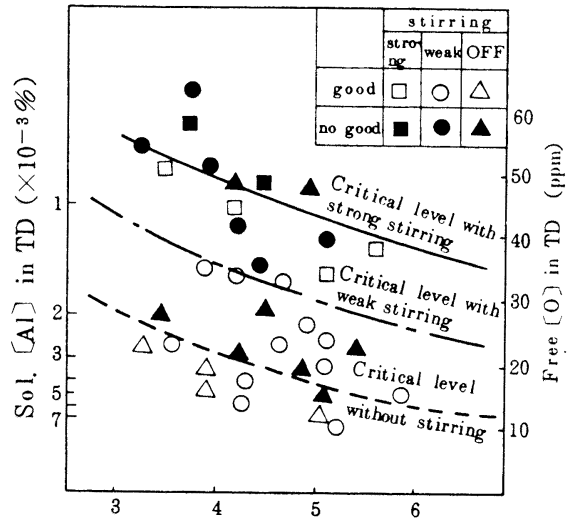

[C] in TD $\left(\times 10^{-2} \%\right)$

Fig. 1 Effect of stirring of molten steel on blow-hole formation

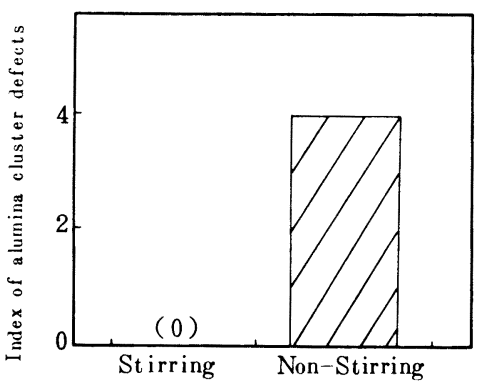

Fig. 2 Effect of stirring on alumina cluster defects in cold rolled coils
2）芝尾ら鉄と銅，68（1982），S 265 


\section{（223）オーステナイト系ステンレス鋼の連鋳鋳片の表面性状改善}

日本鋼管侏 京浜製鉄所 半明正之 栗林章雄 田中 久 ○徳重昇司 都留信朗 中央研究所 菅原功夫

1. 緒言 オーステナイト系ステンレス鋼の連鋳鍀片は, 凝固収縮率が炭素鋼にくらべ大さいため, 鋳片表面の凹凸が一般に大をく、特にコーナー部近傍に割れを誘発しやすい。をた、ステンレス鋼は加 熱炉中のスケールオフ量が少ないため，表層下の微小欠宿 例えばガス気泡やオッシレーション(O.S.) マ 一ク谷間の偏析部等が圧延後鋼板表面疵として残存しやすい。そとで, 304,316 系ステンレス鋼の無手 入れ压延化を目的として京浜 2 号スラブ連鉡機を用いて表面改善を検討したので報告する。

\section{2. 連鋳スラブ欠陥と鋼板表面疵の関係}

Table 1 亿代表的な鋼板表面疵と，その発生原因と なるスラブ久陷を示した。ブロ蹗は、ストッパーから 流すカス $\left(\mathrm{Ar}, \mathrm{N}_{2}\right)$ の残存気泡が主原因であり、カス ブロ流量の減少によりブロ疪は減少する。エッジ割れ 疵は、スラブコーナー部に発生する凝固割れや側面側 の横割れが原囚であり、鋼板表面に発生する縞状模様 は、U.S.マーク谷間に発生する偏析が原因である。

3. スラブ表面性状の改善

(1) コーナー近傍疑固割れ; オーステナイト系特有 のスラブコーナー部から $30 \sim 50 \mathrm{~mm}$ 入った長边面の凹 み部に発生する長さ 1 〜 $10 \mathrm{~mm}$ 程度の割れは, Fig. 1 亿 示すよ5に, 溶鋼過熱度, 鉡造速度が共に大をい程発 生率が大をくなる。また，側面に発生するU.S.ケーク に治った横割れは、鋳造初期のボトム域に発生しやす ら。これらの割れは、Fig. 2 に示すよ5に短边モール ドの強テーパ化により減少する傾向にあるととが確認 された。

(2) U.S.マーク梁さの低減；O.S.サイクル数を 64〜 $255 \mathrm{cpm}$ の間で変更させて，ネガィブストリップ時 間を変えて鉡造し，O.S. マーク梁さ及び表層下の偏析 状況を調査した。その結果を、Fig. 3 亿示す。また。 それぞれの鋳片を無手入れで熱間圧延し，酸洗後の表 面性状を調査したが， $\mathrm{T}_{\mathrm{N}}$ 化 ${ }^{1)}$ は、O.S. マーク深さが 低减し、さらに、鋼板表面に発生する偏析模様が消え るととが確認された。

4. 結言 オーステナイト采ステンレス鋼の連鋳鋳 造方法を上記の結果より変更し，表面性状が改善され た。

参考文献 1) 竹内ら; 鉄と鋼 70（1984）P 687
Table 1 Typical surface defects.

\begin{tabular}{|l|l|}
\hline $\begin{array}{l}\text { surface defects on } \\
\text { plates or sheets }\end{array}$ & \multicolumn{1}{|c|}{ slab surface defects } \\
\hline \hline blow hole & blow hole \\
\hline edge cracking & $\begin{array}{l}\text { solidification cracking trans- } \\
\text { verse cracking at narrow surface }\end{array}$ \\
\hline oscillation pattern & $\begin{array}{l}\text { surface segregation at osillation } \\
\text { mark }\end{array}$ \\
\hline
\end{tabular}

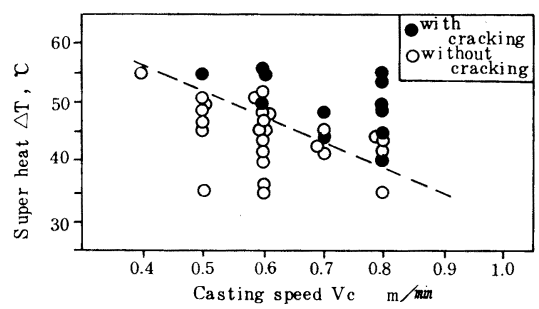

Fig. 1 Effect of casting conditons on solidification cracking.

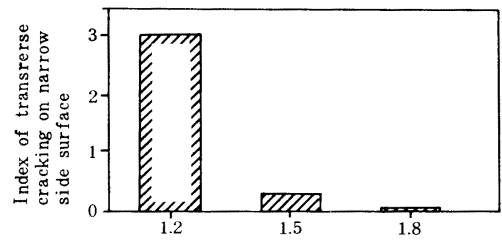

Mold - taper of narrow face

Fig. 2 Relation between index of transverse cracking on narrow side surface and mold-taper of narrow face.

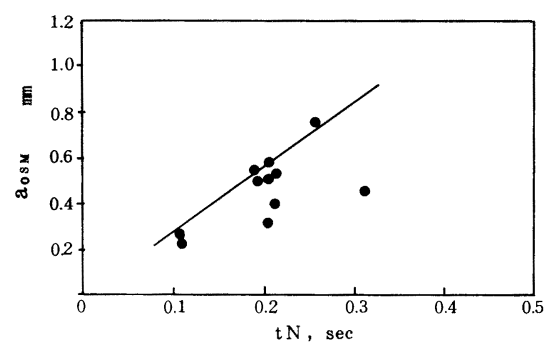

Fig. 3 Relation between negative stripping $t$ ime and depth of oscillation mark 
（224）Ti安定化ステンレス鋼鋳片表層介在物の低隇に対する鋳型内電磁掼拌の効果

日新製鋼（株）周南研究所森川叁山内隆長谷川守弘

1. 緒言 $\mathrm{Ti}$ 安定化ステンレス鋼鋳片では、 $\mathrm{Ti}$ を比較的多量に添加するため $\mathrm{TiN} 介$ 在物に起因した表 面疵が極めて発生しやすい。一方、鋳型内電磁擋拌により鋳片表層部の介在物の低減が可能であるてと が報告されている。本報告では、実験室的に鋳片表層部の $\mathrm{TiN}$ クラスターに対する鋳型内電磁攪轮の効 果を調查した結果について述べる。

2. 実験方法用いたモールドは、断面が $110 \mathrm{~mm} \times 700 \mathrm{~mm}$ 高さが $900 \mathrm{~mm}$ の S US 304 製である。電磁攪挟装置等は以前に報告したので 省略する。はず連鋳パウダーの巻き込みのない攪䢁モードを検剖した。 次いで、0.65\%以上の $\mathrm{T}$ iを含む $18 \mathrm{Cr}$ 系ステンレス溶鋼の凝固初期攪 挟を行なった。攪找モ一ドは水平旋回流とした。攪挟の効果は、鋳片 表面より $3 m m$ の Z断面において評価した。

3. 実験結果 1) パウダー巻さ込みに対する攂䢁モードの影響：鋳 片表面に捕捉されるパウダ一起因の介在物量は、鋳片表面の湯じわの 梁さ、あるいは湯面変動の増大にともなって増加した。同一摫䢁強度 のもとでは、水平方向の一方向流 $\mathrm{A}(\rightrightarrows)$ よりも旋回流 $\mathrm{B}(\rightleftarrows)$ の方が捕捉さ れる介在物量は少なくなり䚓找無しと同程度のレベルであった。

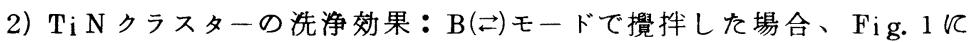
示すようにリニアモーターコア中心に近い压ど、すなわち磁束密度が

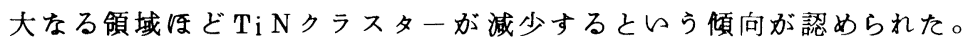
電磁撜找による流動が殆んど及ばない領域でのクラスタ一指数を $\mathrm{I}_{0}$ と し、各位置での指数 Iを割った值 I/ $\mathrm{I}_{0}$ てって洗浄效果を評他した。 デンドライトの偏向角加ら推定した溶鋼流速 $\mathrm{V}_{\mathrm{Fe}}$ と $\mathrm{I} / \mathrm{I}_{0}$ との関係を Fig. 2 亿示す。同図より $25 \mathrm{~cm} / \mathrm{s}$ の流速を与えるととにより $90 \%$ 以上の

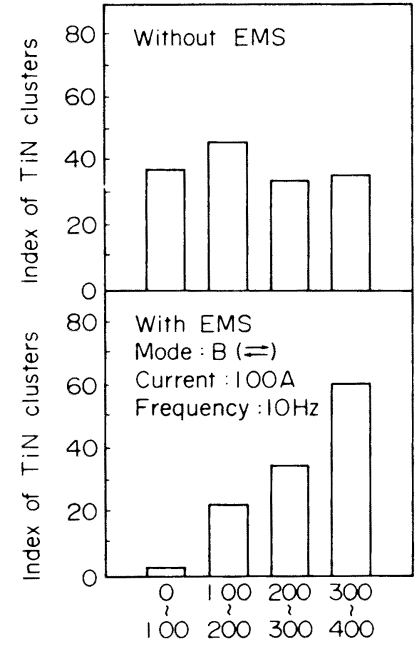

Distance from center of linear motor core : D $(\mathrm{mm})$

Fig. 1 Relation between distance from linear motor core and index of TiN clusters. $\mathrm{TiN}$ クラスターの低隇が可能と推定される。 $\mathrm{VFe}_{\mathrm{Fe}}<5 \mathrm{~cm} / \mathrm{s}$ の領 域および $\mathrm{V}_{\mathrm{Fe}} \approx 25 \mathrm{~cm} / \mathrm{s} の$ 領域から切出したサンプルを熱延、 冷延に供し、冷延板での線状疵を比較した結果、後者の方が明 らかに線状疵が少ないととが確認でをた(Photo１）。

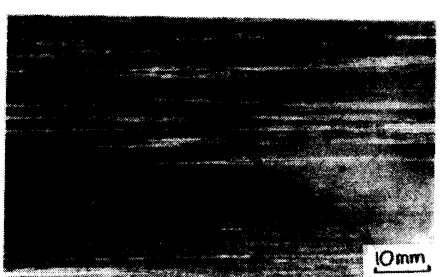

a) $\mathrm{V}_{\mathrm{Fe}}<5 \mathrm{~cm} / \mathrm{s}$

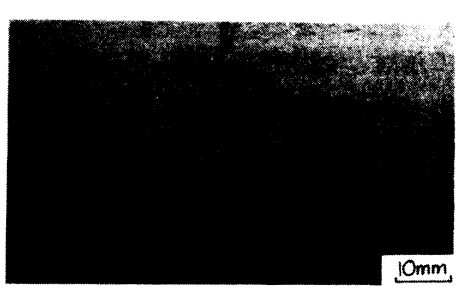

b) $\mathrm{VFe}_{\mathrm{Fe}} \approx 25 \mathrm{~cm} / \mathrm{s}$

Photo. 1 Surface appearance of cold rolled sheets.

文献 1) 例えば竹内ら：鉄と鉬，67（1981）S 833

2) 森川5

：鉄と鋼，70（1984）S 964
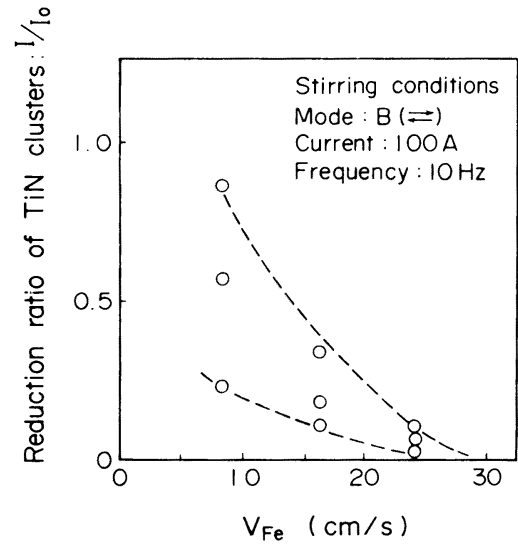

Fig. 2 Relation between $V_{F e}$ and I/Io. 
INTRODUCTION

Since 1984, SOLAER has progressively equiped its 4 Continuous Casting lines with transversal crack detecting systems. This system's function is to direct only the defectuous slabs to the scarfing yard whereas the good slabs are sent directly to the Hot Strip Mill.

The advantages of this system, together with a good production quality level (less than $5 \%$ of defectuous slabs) and in spite of a product mix including difficult steel grades ( $35 \%$ of uediul carbon Steel grades), have enabled us to send directly wore than $90 \%$ of our production as yell as lessenning scarfing costs.

\section{DETECTING AETHOD}

The chosen wethod is that of Eddy Current, the better adapted vethod in detecting surface defects and which also enables to evaluate the defects depth.

Before the head of the sensing system, the slab surface is cooled down to $500^{\circ} \mathrm{C}$, in order to test the product in the ferromagnetic zone. For each constinuous casting strand, two robots keep eight Eddy Current sensors in contact with the slab. The sensor signals are generated and wanaged by a remote controlled channelling electronic equipment. A computer anages the robots moverents and safety arrangements, constinuously optimizes the adjustwent of probing parameters and ensures, throughout an adapted numerical filter, an optimal discrimination between the signals due to defects and those caused by oscillation marks.

RESULTS

The equipment described above ensures an all out automated detection of the defects; all the defects with a depth wore than 2 mat pass under the sensors are located by the system. At the starting of the first installation, a campaign of tests covering 354 slabs, showed that $99 \%$ of the defects were detected by the system and the rate of false alarn did not exceed $2 \%$. This result was confirmed in industrial production with the achieving of $10000 \mathrm{~T}$ of $\times 70$ grade without failure associated with a near $100 \%$ machine availability.

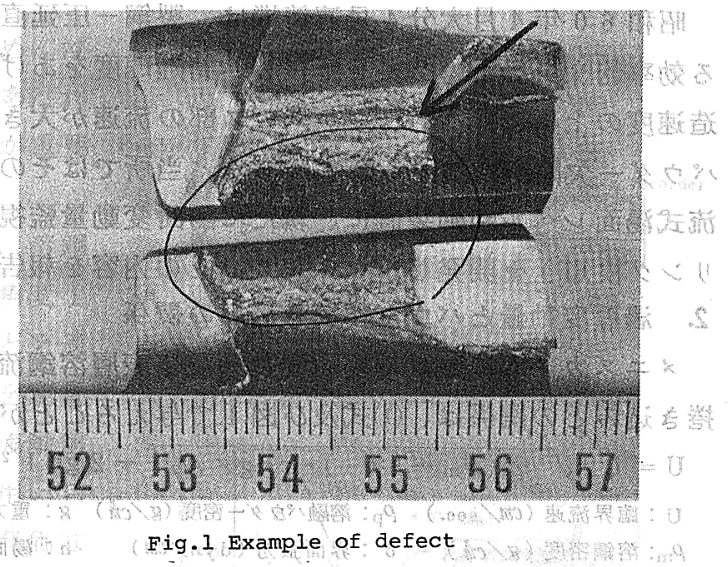

An example of detected defects is given on the above figure. The getting underway of this technique drove to a spectacular advance of direct charging, to-day attaining $92 \%$ corresponding to a $17 \%$ increase.

The diagran hereby, indicates the compared performances of two strands of a sawe Constinuous Caster, one being equiped, the other not.

$$
\text { DIRECT CHARGING RATIO }
$$

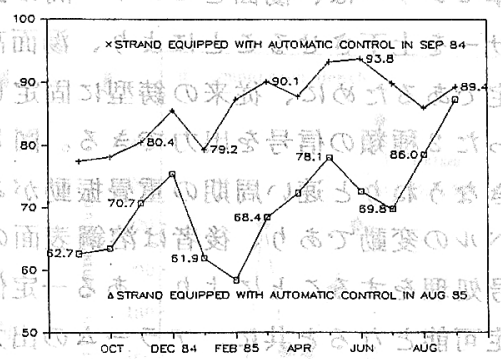
Fig.2 Direct charging ratio CONCLUSIOH

The running of this device gives a higher quality guarentee for our products, as well as allowing a sensible increase of direct charging rate, and an important reduction of interaediate operations. In less than a year, the saving achieved have largely comensated the cost of equipping all the Constinuous Casting strands at SOLMER. 
' $86-\mathrm{S} 1018$

\section{（226）連鋳鋳型内における湯面变動検出装置の開発}

新日本製鐵(株)大分製鐵所

\section{1. 緒 言}

昭和 60 年 4 月大分 4 号連鋳機は、製鋼一圧延直結化のさらな ろ効率的操業を狙い機長を延長し、鋳造速度をあげた。一般に鋳 造速度の上昇に伴ない、メニスカス部の流速が大きくなるために、 パウダー欠宿が増加する䅣念がある。当所ではその対策として渦 流式湯面レベル制御装置に、新たに湯面変動量監視機能 ( リップ リング検知）を開発した。本報ではその内容を報告する。

\section{2. 晹面変峌量とパウター捲き込みの関係}

メニスカス部における湯面変動量及び表層溶鋼流速とパウダー 捲き込みとの関係は、(1)式及び困 1.で与えることができる。

$$
\begin{aligned}
& \mathrm{U}=\left\{2 \sqrt{12\left(\rho_{\mathrm{m}}-3 \rho_{\mathrm{p}}\right) \cdot \sigma \cdot \mathrm{g} / \rho_{\mathrm{p}}{ }^{2}}-2 \mathrm{gh}\right\}^{1 / 2} \\
& \mathrm{U} \text { : 臨界流速 }(\mathrm{cm} / \mathrm{sec} \text {. }) \quad \rho_{\mathrm{p}} \text { : 溶融パウダー密度 }(\mathrm{g} / \mathrm{cm}) \mathrm{g} \text { ：重力加速度 }\left(\mathrm{cm} / \mathrm{sec}^{2}\right) \\
& \rho_{\mathrm{m}} \text { : 溶釷密度 }(\mathrm{g} / \mathrm{Cm}) \quad \sigma \text { : 界面張力 }(\mathrm{dyn} / \mathrm{Cm}) \quad \mathrm{h} \text { : 湯面変動量 }(\mathrm{mm})
\end{aligned}
$$

すなわち、メニスカス部の表層流速が大きい場合、パウダー捲き 込みを発生させないためには、湯面変動量を小さく抑える必要が ある。従って、高速鋳造時では湯面制御精度の向上が必要である。

\section{3. 渦流式リップリンク検出装雷}

汹 2 に渦流式湯面センサーの構成を示す。(A)部は従来の湯面レ ベル制御機能であり、(B)部は今回開発したリップリング検出機能 である。本センサーは、湯面とセンサー間の距離を一定に保つた めにセンサーを上下させることにより、湯面高さに関係なく測定 感度が一定であるために、従来の鋳型に固定したタイプでは計測 し得なかった 2 種類の信号を出力できる。四 $3(\mathrm{~A})$ に出力信号を示 すが、大きなうねりと速い周期の重畳振動がみられる。前者が溶 銅湯面レベルの変動であり、後者は溶銿表面の異常振動である。 B 部で信号処理をすることにより、ある一定值以上の湯面変動の 個数が測定可能となると共に、アラームの出力がされる。

\section{4. 湯面变動回数と介在物品質との関係}

圀 4 に本装置により検出した湯面変動回数と製品品質レベルと の対応関係を示す。本法により製品品質レベルとして許容可能な 湯面変動回数を決定できるようになった。また湯面変動に影慗を 与えろ操業要因の定量的評価が可能となり、湯面変動減少のため の操業技術の改善にも貢献することができ、高速鋳造下でも介在 物は低減できるようになった。

\section{5. 結 言}

渦流式リップリング装置の開発により、高速鋳造下でもパウダー 捲き込みが抑えられ、介在物欠陥のない安定した操業が可能となった。
○湯山英俊，堅尾茂樹，常岡 聡 大滝慶一，松田直也

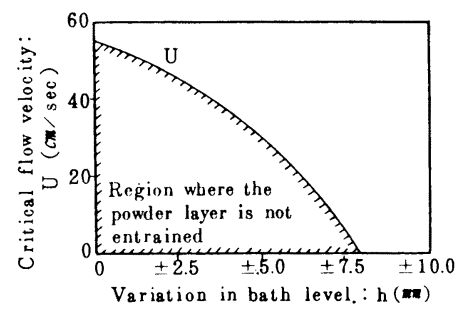

Fig. 1 Relationship between variation in bath level and critical flow velocity for ent raining

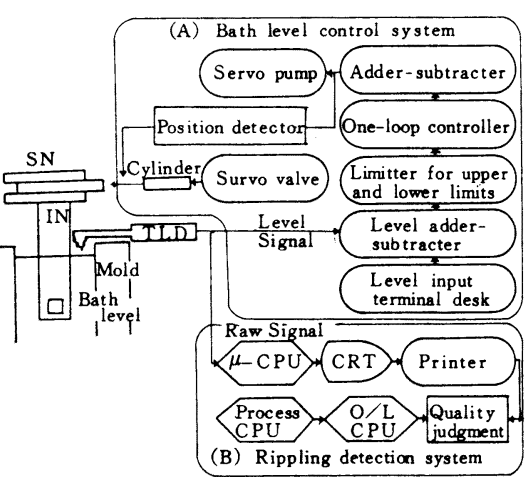

Fig. 2 TID rippling detection system

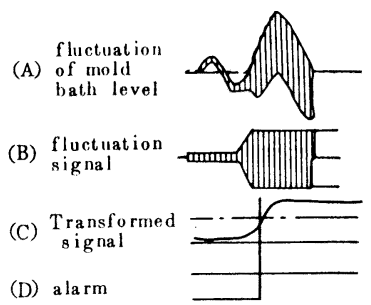

Fig. 3 Example of out put signal
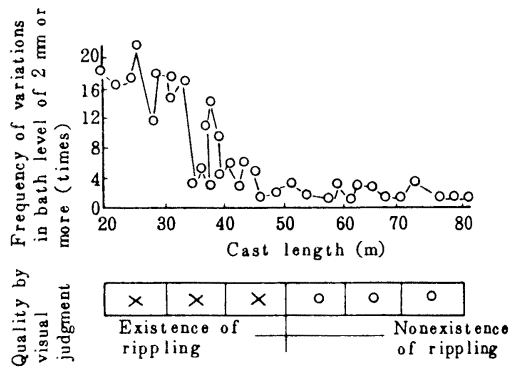

Fig. 4 Relationship between frequency of variations in bath level and quality 
（227）赤外線サーモグラフによるモールド内流動現象の測定

日本鋼管侏）京浜製鉄所

\section{1. 緒言}

連続鋳造法により清净度の高い製品を製造するためには モールド内の溶鋼流動を適正にコントロールし、湯あばれ によるモールドパウダーの巻を込みを防止するととが重要 である。

モールド内溶鋼流動をコントロールするためには，溶鋼 吐出量に応じた 浸漬ノズル形状（吐出口径, 吐出角度) 浸漬ノズル浸漬梁さ、モールド内Ar吹を込み量などを適 正化する必要がある。従来これらの要因による影響を定量 化する手法として、水モデルを用いた方法、三次元流動解 析，実機におけるモールド内湯面変動の測定などが用いら れている。しかし実機における個々の要因の定量的評価は 十分とは言えない。本報告では実機におけるモールド内流 動現象の評価法として赤外線サーモグラフの適用例につい て報告する。

\section{2. 測定法}

赤外線サーモカメラにより，モールドパウダー表面温度 の分布、上年速度を測定しモールド内溶鋼流動を推定する。 (Fig. 1)

\section{3. 結果}

モールドパウダー表面温度はモールドパウダー未溶瀜層 厚と相関が有り,モールドパウダー表面温度分布, 温度上 具速度から，モールド内溶鋼流動に起因するモールドパ ウダー厚の分布を測定するととがでをる。（Fig. 2)

モールドパウダー表面温度上年速度に及焉す浸漬ノズ ル浸漬梁さ、およびモールド内吹込A $\mathrm{r}$ 量の影響を定量的 に評価するととがでをる。モールドパウダー表面温度上昇 速度は，浸漬梁さを大とし，Ar量を小とするととで低下す るとともに、巾方向のバラッキす低减させるととがでをる。 (Fig. 3)

この手法を用いると、モールド内偏流等のメニスカス部 における溶鋼流動状況を定量的に把握でを，モールドパウ ダー巻さ込み防止技術の開発等に役立てることが可能とな った。
半明正之

山上 淳

松村千史
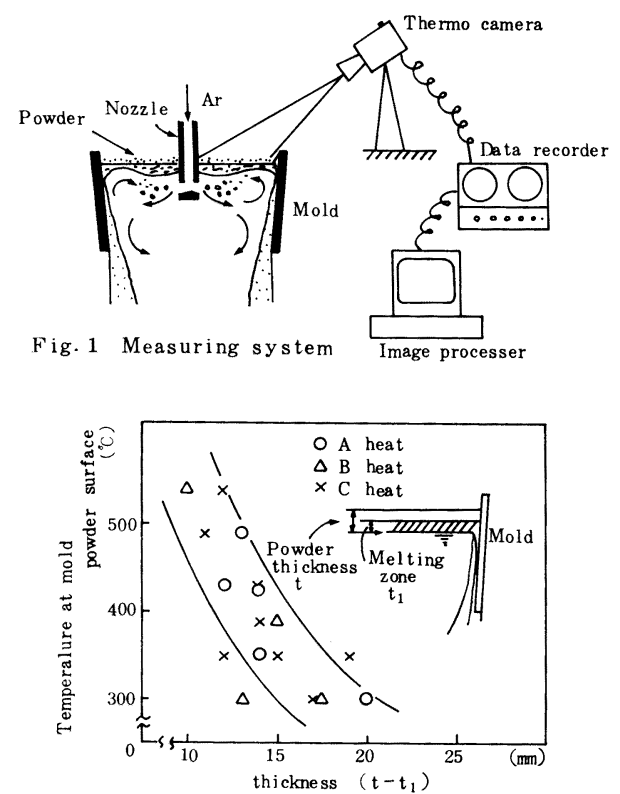

Fig. 2 Relation between mold powder thickness and mold powder surface temperature

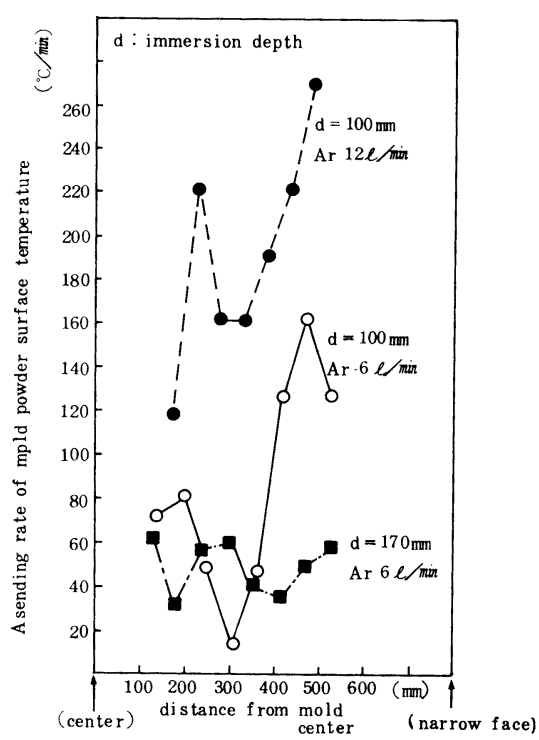

Fig. 3 Influence of Ar flow rate on ascending rate of mold powder surface temperature 
新日本製鐵(侏) 名古屋製鐵所 $○$ 森 正晃

大崎畺宏
伊藤昭博 小林 功

長谷真二

\section{1. 緒 言}

連続鋳造におんて, 空気酸化による品質問題及び, 自動化・省力化の観点より, 作業者の目視判定 によらない自動スラグ流出検知法の開発が望まれている。てれまでにも種々のアプローチがなされた が, 地金付着等の操業外乱により，安定な検知法の確立には至っていない。今回、ロングノズル内の 圧力の変化よりスラグ流出を安定して検知でをたので報告する。

\section{2. 検知原理}

Fig...1亿示すように，ロングノズル内は 溶鋼落下流により雾囲気がスがたたを込ま れ, 気泡としてノズル外へ持ち去られると 考えられる。従ってノズル内は負圧となる が，こてで溶鋼流中に大量のスラグが混入 すると, 落下物の比重 - 粘性の差により, 雲囲気ガスをたたを込むエネルギーが急激 に低下する。乙のよ5な現象のため,ノズ ル内の負压は急激に小さくなり，乙の時の 圧力変化を測定するととで，スラグ流出を
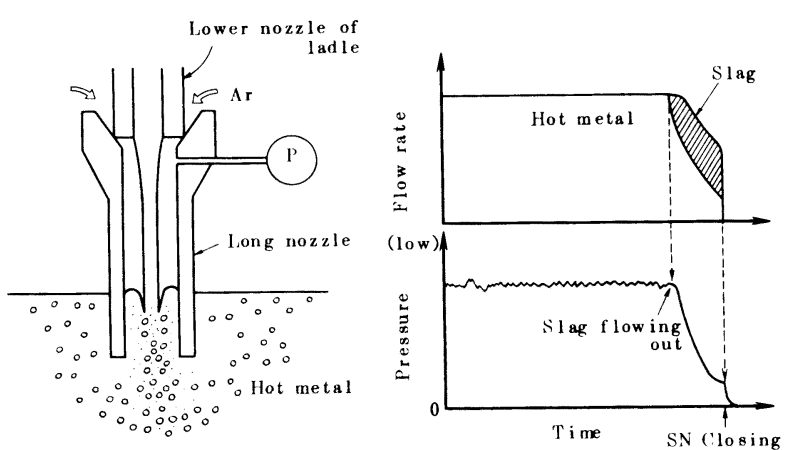

Figs.l Principle of detection for slag flowing out by pressure method 検知するものである。

\section{3. 実機テスト結果}

名古屋製鐵所 $1 \mathrm{cc}$ の鍋〜タンディッシュ間のロン グノズルに,Fig.2のような装置を設け, 実操業に おいて匠力を測定し, マイコンによりスラグ流出警 報を出すテストを実施した。

テストの結果，(1)鍋下ノズル〜ロングノズル間の シール性向上, (2)匠力取り出し法の改良, に上り1 cast (6ch) 連続して, 目視判定より $1 \sim 3$ 秒程度早目に検知することがでをた。さら に, 目視判定では, カバースラグの影響や 個人差により，かなりスラグ流出検知のタ イミングにばらつをがあるが，本法ではほ とんどばらつをが解消された。匠力変化の 一例を Fig.3 亿示す。

\section{4. 結 言}

ロングノズル内の压力変化を㭘出するこ とで, 地金付着等の操業外乱に影響されな レスラグ流出検知法を開発し, 今後実機化 を予定している。

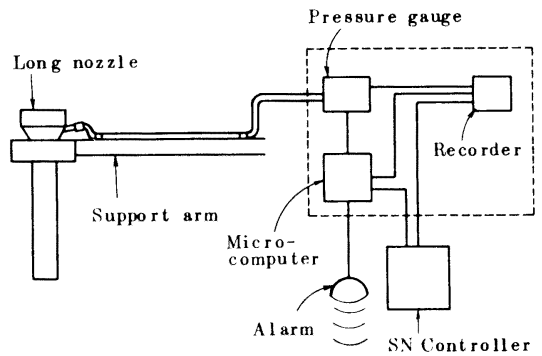

Fig.2 Schematic system diagram

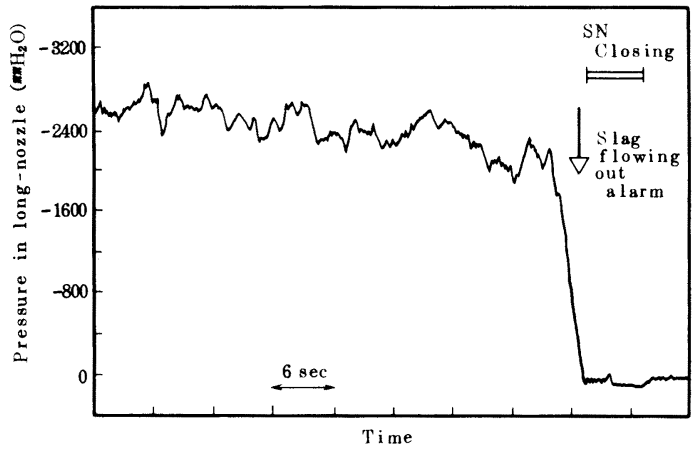

Fig.3 Typical result of measurement 


\section{1. 緒 言}

連続鋳造機の操業において，熱片装入（H C R），直送圧延（H D R）の拡大等，製鋼〜圧延工程間 の製造ラインの連続化が進む中で, それに対応した迅速且つ正確な品質管理が要求されている。とうし た要求に応えるため, 福山スラブ連鋳機において各種計測設備の利用による鋳造状態の監視及び鋳片品 質のオンライン予測を目的とした鋳造品質予測システムを開発したのでその概要を報告する。

2. システムの構成

図ー 1 に福山のスラブ連鋳機における計測設備と本シ ステムの概要を示す。各データはプロセスコンピュータ $(\mathrm{P} / \mathrm{C})$ に取込まれ， $\mathrm{P} / \mathrm{C}$ 内部で鋳片単位に編集整 理される。こうした編集データを，あらかじめ $\mathrm{P} / \mathrm{C}$ 内 にマスタ一化してある判定基準に照らして, 鋳片の品質 判定, 処置決定を自動的に行なら。また同時に, 鋳片単 位に編集されたデータは上位のセンターコンピュータに 后送記憶され，圧延データとマッチングさせて解析する ととも可能となっている。

3. 品質判定条件の決定

鋳片の品質判定基準を決定するにあたって，事前に鋳 片単位に編集された操業データと鋳片表面欠陥及び製品 欠陥との相関を調查した。困-2にその1例を示す。ま た， 1 種類の操業データだけで評価できない欠陥につい ては, 数種類のデータを組合わせた指数を用いて評価し た。とうした調査により, 各鋼種グレードに応じた最適 な操業条件の把握が可能となり, その範囲から逸脱した ものを異常と判定するとととした。

\section{4. 操業結果}

本システムの稼動により, 従来のオペレータ判定の場 合と比べて操業管理の精度は大巾に改善され，製品での 欠陷発生も低減している。また, 異常発生時の処置決定 もオンラインで行なわれるため, 従来のように鋳片保留 〜処置決定というプロセスが不要となり, 物流フローも 大巾に改善された。

\section{5. 結 言}

鋳造品質予測システムの開発により, H C R, H D R に対応した品質管理が可能となった。また, 今後の計算 機による品質つくり込み制御への基礎データが得られた。 参考文献瀬良ら：鉄と鋼（1982） 3 , S 138

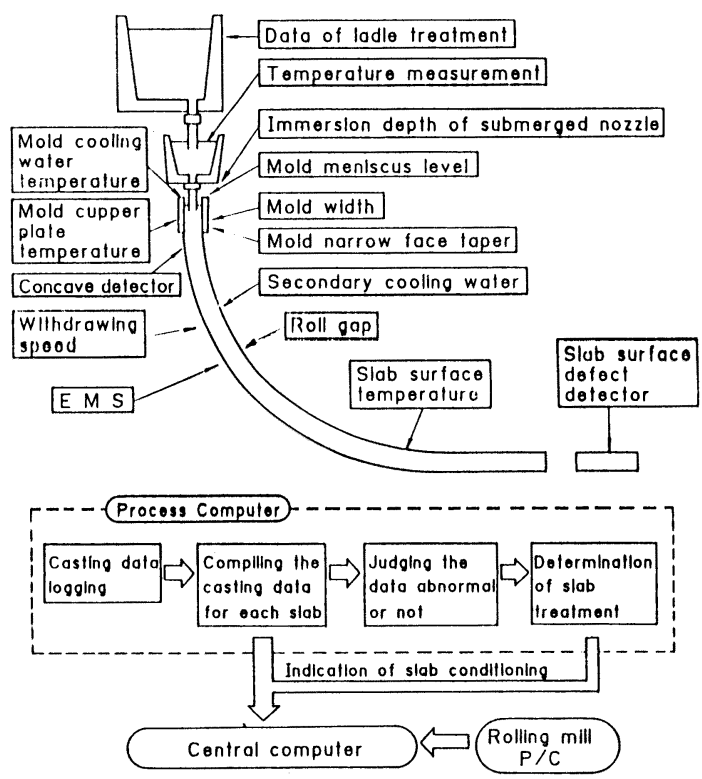

Fig.- I Out-line of slab qually estimation system for continuous casting.

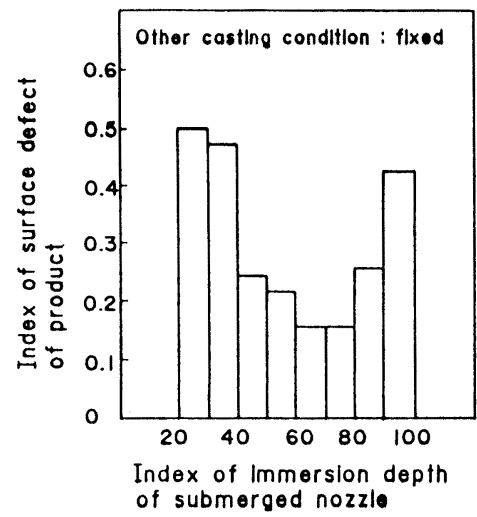

Fig.-2 Relation between Immersion depth of submerged nozzle and surface defect of product. 
（230）速锈用浸清・ズルの局部容損上光の防止策

$$
\begin{aligned}
& \text { 几工大响井楠宏 } \\
& \text { トロント大学 J.M. Toguri, N.M. Stubina } \\
& \text { 黑崎弿業(株) }
\end{aligned}
$$

\section{1、绪言}

アルミナ・グラファイト(AG) 系の浸漬ノズルは,パウダーーメタ

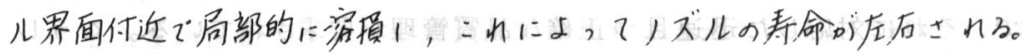
:の系の局部容椇は, AG)ズルの主成分であるグラファイトと酸化物

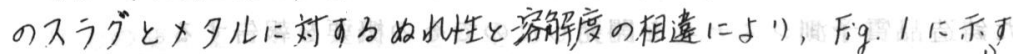

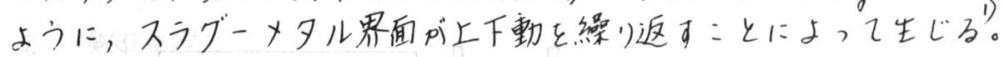
(a)ではスラグフィルム中に酸化物叶溶解に，(b)ではメ夕ル中にグラ ファイト溶解可子。

連鏻のようにC浱度の低・とこ3では, (b)の時期は(a)に比べて著

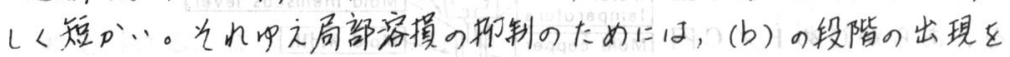

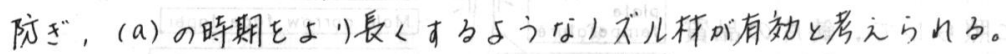

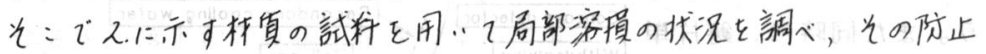
策を检計、た。

\section{2. 方法}

$A G\left(\mathrm{Al}_{2} \mathrm{O}_{3} 40 \%, \mathrm{SiO}_{2} 18 \%, \mathrm{Z}_{\mathrm{Z}} \mathrm{O}_{2} 7 \%\right.$, siC $\left.7 \%, \mathrm{C} 28 \%\right)$, AGBN $\left(\mathrm{Al}_{2} \mathrm{O}_{3} 36 \%, \mathrm{SiO}_{2} 7 \%, \mathrm{SiC} 10 \%, \mathrm{C}_{2} 3 \%, \mathrm{BN} 24 \%\right), \mathrm{ZG}\left(\mathrm{ZrO}_{2} 75 \%\right.$,

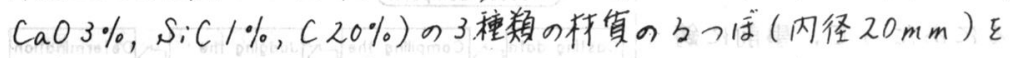

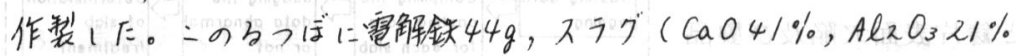
SiOz $38 \%$ ) $8 \mathrm{~g}$ \& 入 $1550^{\circ} \mathrm{C}$ のとで線透過装置を用”て子つ代内 壁のスラグーメ夕ル界面付近の局部容椇の状况を 直接観察1た。

\section{3. 結果}

1) AGBNろつぼ; :のるつはでは，Photo.1 (b)に示すように,つ訃にFig.l一- (a)の段階にあ 1)，(が溶損はスうブーメ夕ル界面の下の全領 域でほぼ一様に進行す夕。しいしるつぼのへ二ナ 量はAGるつま゙（Photo１－(a)）での最大局部容 賣部のヘンタ量の羊分以下であり， BNの添加が
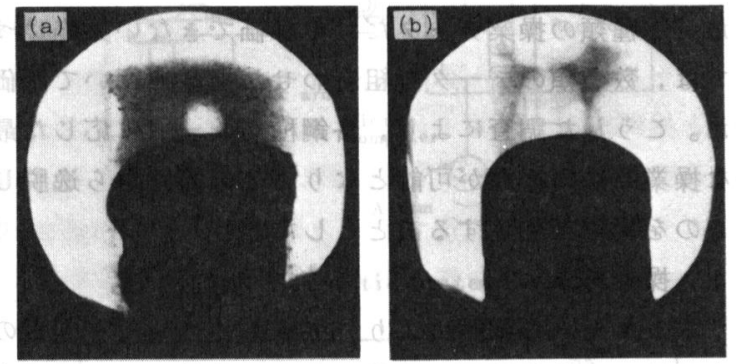

Photo.1 Shape of the slag-metal interface during the progress of local corrosion. (a) AG crucible, (b) AGBN crucible. 局部容掑の防止に一定の効力を持つことがか子。
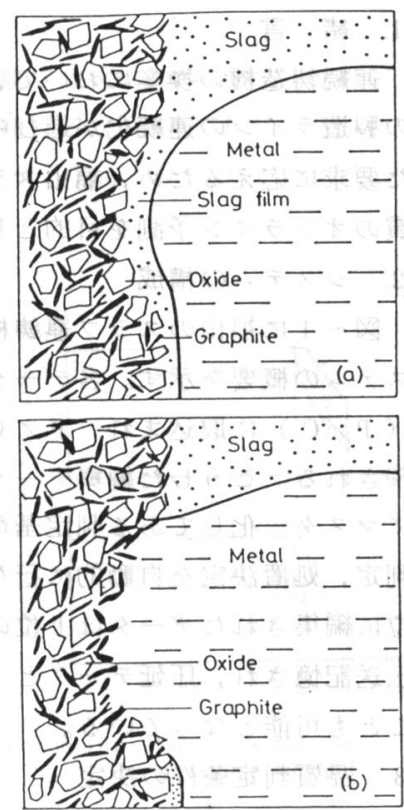

Fig.1 The manner in which local corrosion proceeds.

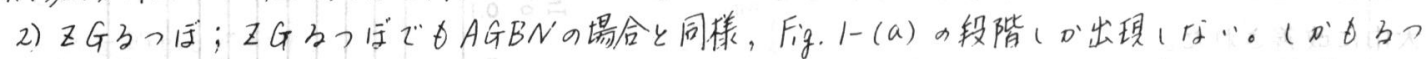

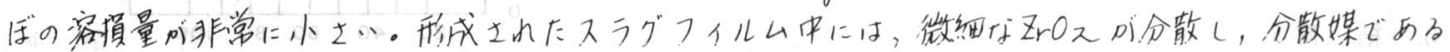

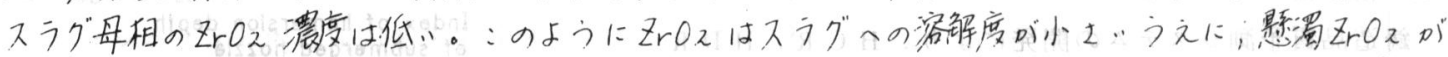

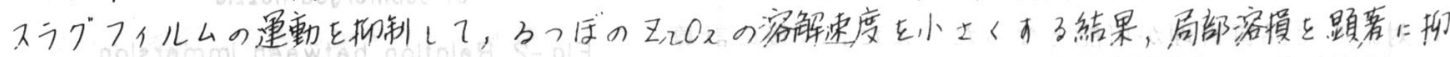
制可る成分に「少门るものと考之的方。

1) K. Mukai et al; 5th I. I.S.C., April, 1986 Washington D.C. 
新日本製鐵(侏) 名古屋製鐵所。四阿 佳昭大堀 潤二

旭碍子(侏) 研究開発部酒井 恒蔵林

1. 緒 言 製銑・製鋼工程におらて, 溶銑・溶鋼の温度管理は操業・品質の安定化にとり非常に重 要である。従来の温度測定は, 消耗型の浸漬式温度計を用い, 熱電対溶損に至る数秒間の断続的測定に よ゙るもので, 連続測温による温度管理が強く望をれていた。今回, 耐熱性・耐熱衝撃性・耐食性に優れ た嗍化ジルコニウム $\left(\mathrm{ZrB}_{2}\right)$ 系セラミックスを熱電対保護管に実用化し，溶銑・溶鋼の長時間連続測温 に成功したので報告する。

Table 1. Proper ty data of typical advanced ceramics

2. 測温用保護管材質の検討連続測温用保護管の 材質としては, 耐熱性・耐食性・耐熱衝撃性・強度等 が要求される。各種セラミックスの物性例をTable.1 に示す。乙れらの中で $\mathrm{Z} \mathrm{r} \mathrm{B}$ は溶鋼浸食試験において 最も耐食性飞優れ, 他の性質も良好であり, 最近その 成形・量産技術が確立されたため, 連続測温用保護管 への $Z \mathrm{rB}_{2}$ 応用に着手した。

\section{3. $\mathrm{ZrB}_{2}$ の適用検討}

3.1. 予熱温度 Fig.1亿示すように, 種々の予熱

\begin{tabular}{|c|c|c|c|c|}
\hline \begin{tabular}{|ll} 
Croperty & Ceramics \\
\end{tabular} & $\mathrm{ZrB} \mathrm{B}_{2}$ & $\mathrm{~A}_{2} \mathrm{O}_{3}$ & B N & $\mathrm{Si}_{2} \mathrm{~N}_{4}$ \\
\hline Densi ty & 3.9 & 3.8 & 1.7 & 3.1 \\
\hline $\begin{array}{r}\text { Bending strength } \\
{[\mathrm{kg} / \mathrm{m}]} \\
1200^{\circ} \mathrm{C}\end{array}$ & $\begin{array}{r}10 \sim 15 \\
6 \sim 11\end{array}$ & $\begin{array}{l}34 \sim 40 \\
17 \sim 20\end{array}$ & $\begin{array}{c}2.4 \sim 4.5 \\
-\end{array}$ & $\begin{array}{l}60 \sim 70 \\
30 \sim 35\end{array}$ \\
\hline $\begin{array}{l}\text { Fracture toughness } \\
{\left[\mathrm{MN} / \mathrm{m}^{3 / 2}\right]}\end{array}$ & 3.2 & - & - & 5.3 \\
\hline $\begin{array}{r}\text { Thermal conductivity } \\
{\left[\left(\mathrm{lat} / \mathrm{mh}^{\circ} \mathrm{C}\right]\right.}\end{array}$ & $23 \sim 29$ & $8 \sim 10$ & $49 \sim 50$ & $16 \sim 17$ \\
\hline 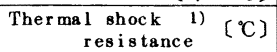 & $\stackrel{550}{\sim 600}$ & $\stackrel{200}{\sim 250}$ & $1500<$ & $\stackrel{750}{\sim 800}$ \\
\hline Melting point & 3060 & 2050 & 2970 & 1900 \\
\hline $\begin{array}{c}\text { Corrosion resistance } \\
\text { to molten steel }\end{array}$ & A & $\mathrm{C}$ & B & $\mathrm{C}$ \\
\hline
\end{tabular}

1) Quenching in cold water

温度に保持した $Z_{\mathrm{rB}}$ 試験片を溶鋼中に浸漬する方法

2) Immersion in molten steel

$\mathrm{A}($ Good $) \longrightarrow \mathrm{C}(\mathrm{NG})$ により耐熱衝撃性を言価した結果, 溶鋼温度 $1550{ }^{\circ} \mathrm{C}$ の場合, 予 熱温度は $900^{\circ} \mathrm{C}$ 以上で使用可能との結論を得た。

\section{2. 保護管の設計 (1) F E M (有限要素法) 解析により求め} た熱応力, 温度変化に対する応答性, (2) Z r B 形技術, (3)実操業への適用性（操作性）等老考虑し, 保護管の肉 厚, 形状 - 寸法を決定し, Fig.2 亿示す構造の連続測温用温度計 を製作した。熱電刘には白金一ロジゥム系を使用し, $\mathrm{A}_{2} \mathrm{O}_{3}$ 管と 今回開発の $Z \mathrm{r} \mathrm{B}_{2}$ 管の 2 重保護構造とした。

4. 実操業における溶銑・溶鋼連続測温結果 今回開発の温度 計（Fig.2）を用いて，高炉出銑樋および連続鋳造設備タンディ ッシュ内におんて溶銑および溶鋼の連続測温を行なった。Fig.3 に測温データの例を示す。(1) 温度偏差: 従来の消耗型温度計に 比へ $5{ }^{\circ} \mathrm{C}$ 以内, (2) 初期応答速度： $1 \sim 2$ 分 $\left(950{ }^{\circ} \mathrm{C} \rightarrow 1550^{\circ} \mathrm{C}\right)$, (3)耐久性：溶鉄にて 28 時間，溶鋼にて 12 時間（浸食速度0.06 $\sim 0.17 \mathrm{~mm} / \mathrm{hr}$ ) と, 長時間の連続測温が可能であった。

5. 結 論 $Z \mathrm{rB}_{2}$ セラミックス応用による温度計を開発し, 溶鉄 ·溶鋼の長時間連続測盜に成功した。現在, 更に長時間の連 続測温を可能とするために, 保護管材質 - 構造の改良に取組むと 共に, 実操業への連続測温装置の導入を計画している。今回開発 した連続測温の技術は, 今後の操業ならびに品質の安定化に大き く寄与するものと期待している。

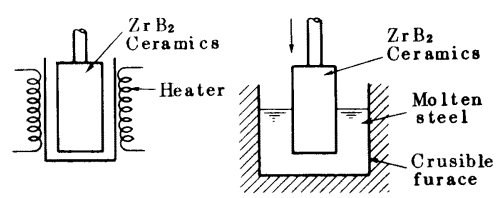

(A) Pre-hesting (B) Dipping into molten steel Fig.1. Estimation of thermal shock resistance

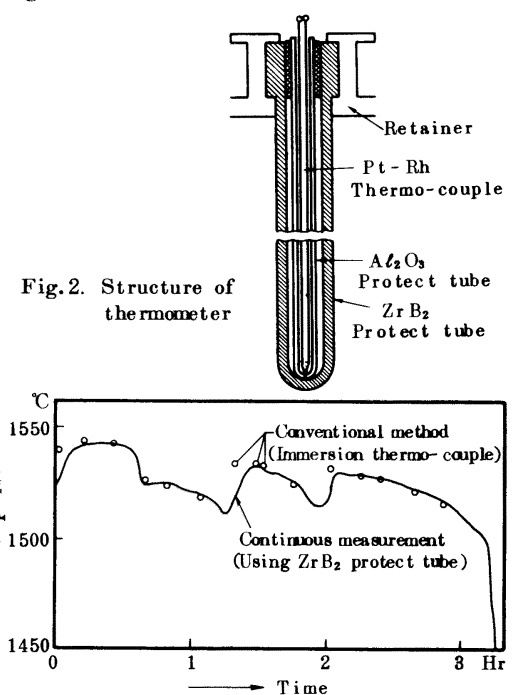

Fig.3. An example of continuously measured temperature 
' $86-\mathrm{S} 1024$

\section{（232）＼cjkstart室蘭製鋼工場溶鋼輸送設備の建設と操業}

新日本製鐵（株）室蘭製鐵所井上隆岡崎 已次佐藤 久

星野 東司 高山 恵一

\section{1. 緒言}

当所の製鋼工場は、従来の第 1 製鋼、第 2 製鋼の二製鋼工場体制から、生産規模に見合った設備対策 として、S60年10月より、第 1 製鋼工場への転炉精鍊の集約を行った。但し、垂直型スラブ連鋳機で高 炭素鋼を製造する為、第 1 製鋼工場から第 2 製鋼工場迄、約 $1 \mathrm{~km}$ 溶鋼輸送を行っている。当設備は効率 の良い設備投資と、ハンドリング時間短縮による溶鋼温度の低下抑制を行う為、狭軌条の台車と、従来 の小型の取鍋を使用した、直接受鋼方式により順調に操業を行っている

ので、以下にその概要を報告する。

\section{2. 設 備 概 要}

Table - 1 亿設備仕様を示す。

\section{3. レイアゥト}

Fig. 1 亿溶鋼輸送関係設備レイアウトを示す。

第 1 製鋼工場入口の取鍋予熱装置で、溶鋼輸送台車上の取鍋を 加熱した後、同台車と既設受鋼台車を連結し、直接受鋼したのち 第 2 製鋼工場迄ディーゼル牽引する。

\section{4. 本設備の特徵}

Fig. 2 亿炉下関係状態図を示す。

1) 狭軌条の溶鋼輸送台車により直接受鋼する。炉口地金落下 等による転倒防止としてアウトリガーを設置し、Table -2 に示 す様に転倒モーメント 1 ・ 0 以下を確保し転倒防止を図った。

2 ）転炉自動出鋼を実施する為、既設システムとのリンケージ を図った。

3) トラニオン防㳯カバーにより、進行方向に位置する取鍋卜 ラニオンを、出鋼時の溶涬飛散から防護した。

4 ）輸送中の溶湯漏洩事故対策として、万が一溶鋼が漏れた場 合でも漏湯が直接道床に落下しない様、台車に受且を設置すると ともに、ルート中間位置にも上屋付非常ピットを設置した。

\section{5. 操 業 結 果}

第 1 製鋼工場での取鍋ハンドリングが不要であり、スラブ 連鋳向け溶鋼は Table-3 亿示す様に、鍋蓋掛け外しを含め て、11分 $/ \mathrm{CH}$ の増加時間と、温度低下 $8.2{ }^{\circ} \mathrm{C}$ のみで、対処 出来た。

\section{6. 結 言}

狭軌の台車で、大型転炉より小型の取鍋に直接受鋼し、既 設線路ルートを活用した溶鋼輸送設備は、計画通り順調に稼 働している。

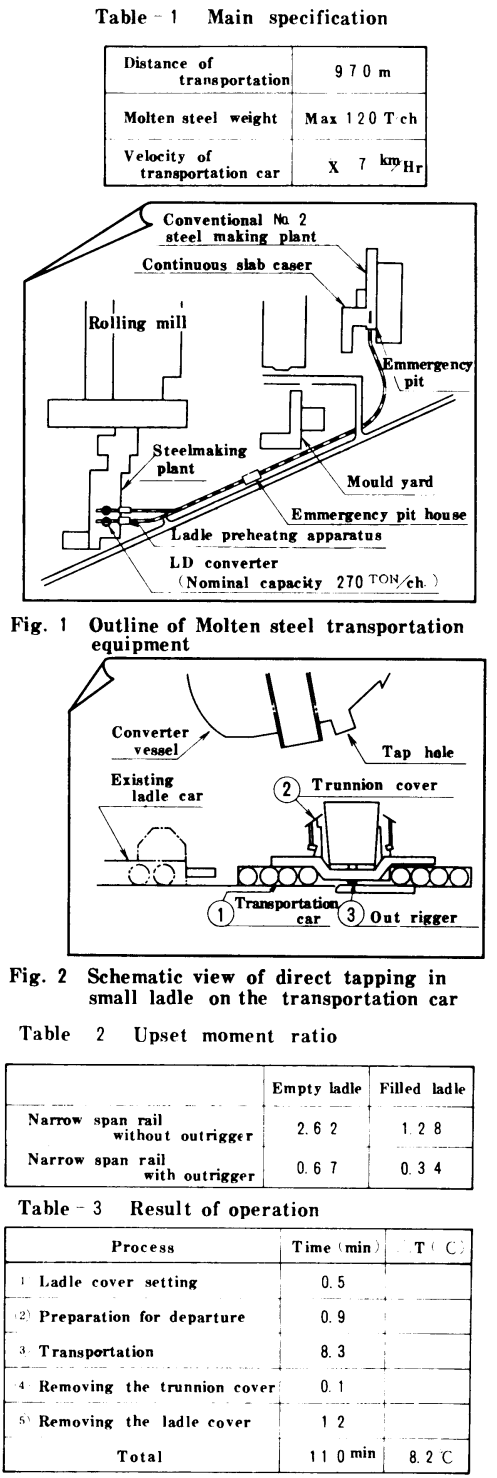




\section{（233）－方向凝固鋼塊のミクロボロシティについて}

（一方向凝固法による極厚鋼板製造技術の確立 4 )

新日本製鐵(侏) 名古屋製鐵所 猪狩繁範 0 田中睦人 工博岡本健太郎嶋宏

名古屋技術研究部工博佐伯毅丹羽裕

1. 緒 言

極厚鋼板製造におらて，普通造塊材ではマクロボロシティ生成により製品板厚に限界がある。しかし， 一方向凝固（UDS）鋼塊は, 凝固方向が一方向のためマク口的な凝固収縮に伴らポロシティは発生せ ず極厚鋼板の製造に適している。当社では, U D S 法により最大鋼塊単重 80 ton.最大板厚 $450 \mathrm{~mm}$ 製造技術を確立している。今间，UD S 鋼塊のミクロポロシティについて調査したので報告する。

\section{2. 調查方法}

$\mathrm{SS} 41$ ・ SM 50 - S C 龬ならびに $2 \frac{1}{4} \mathrm{Cr}-\mathrm{Mo}$ 鋼をU D S 造塊 し, 鋼塊におけるミクロポロシティの生成につんて顕微鏡的な 調査を行なった。また, 製品評価は超音波探賃試験で行なった。

\section{3. 調查結果}

(1) 鋼塊におけるミクロポロシティ鋼塊断面でのミクロ ポロシティ観察の模式戍をFig.1亿示す。また, 鋼塊高さ（h） 方向のミクロポロシティ分布を Fig.2 亿示す。ミクロポロシテ ィは $\mathrm{h} / 2$ 以上飞生成するが，その大ささは $0.2 \mathrm{~mm}$ 以下であっ た。ミクロポロシティの発生個数は鋼種により異なる。

(2) 鋼板におけるミクロポロシティ鋼板でのミクロポロ シティは、鋼塊でのポロシティ分布と圧延によるポロシティ圧 着効果 ${ }^{(2)}$ 相和によるものと考えられる。(Fig.3) ゆえに, 製 品品質上問題となる大ささのポロシティは鋼板に残存しない。

（3）超音波探傷試験 J I S G 08001010 倍の感度 で超音波探賃を行なった結果, 鋼板厚 $450 \mathrm{~mm}$ で無欠陥合格で あった。(Fig.4)

\section{4. 結 言}

U D S 鋼塊のポロシティは小さく, 鋼塊表面近傍に存在す るため製品品質上問題となる大ささのポロシティは鋼板に残 存せず，最大板厚 $450 \mathrm{~mm}$ の鋼板が製造でをた。

参考文献 (1) 堀 ら; 鉄と鋼 71 ( 1985 ), S 265

(2) 菊竹ら; 鉄と鋼 $63(1977)$, S 219

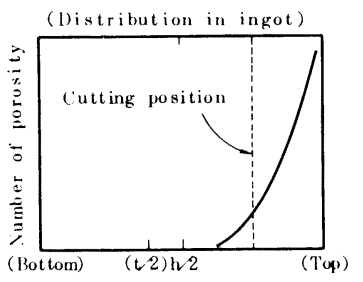

Position of ingot height

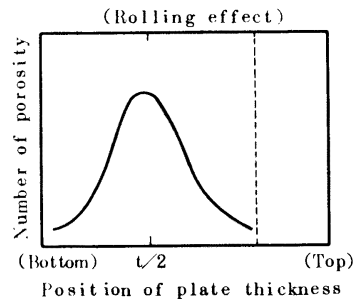

Position of plate thickness
Fig. 3. Elfect of distribution of porosity in plate on rolling

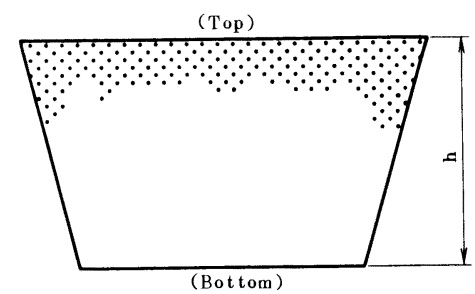

(Size of porosity) $\leqq 0.2 m$

Fig.1. Porosity of ingot

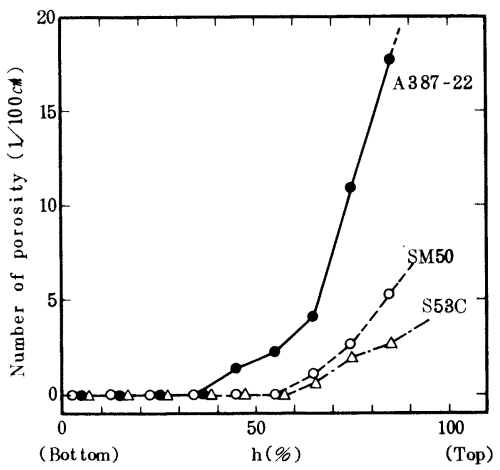

Fig.2. Distribution of micro porosity in ingot

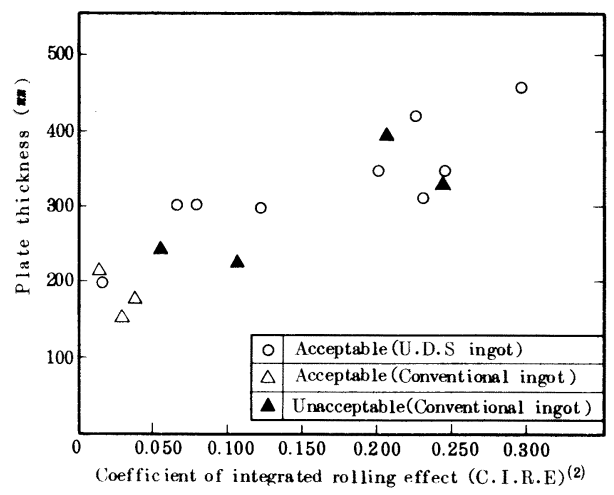

Fig.4. Result of ultrasonic examination (10times more sensitive than J IS G0801) 
' $86-\mathrm{S} 1026$

川崎製鉄(株)鉄鋼研究所

水岛製鉄所
○斎藤健志, 中西恭二, 小口征男

八百 升, 相沢完二, 加藤敏雄

1. 緒言

鋼塊内のC偏析は銅種、鋼塊形状、さらに准固条件によって異なる。COMON"により C最大偏析推定式か報告されて いるが准固条件が加味されず、また偏析分布の推定もできないので十分とはいえない。しかし、近年の凝固シミュ レーションの進歩により C偏析分布の推定が可能になってきた。本報告では凝固シミュレーションによる中空銅塊の C偏析分布推定法について述へる。

2. 方法

中空鋼塊のC偏析推定式を次のようにして求めた。

凝固界面における固一液の溶質分配はBurtonの式で与えられるが、 さらに鋼種の影響を考虑してパラメータ Aを用いて次式で与えた。

$\mathrm{Cs} / \mathrm{CL}_{\mathrm{L}}=\mathrm{k} 0(\mathrm{k} 0+(1-\mathrm{k} 0) \exp (-\mathrm{A} \cdot \mathrm{V}))^{-1}$

凝固率Gの位置からさらに 次の関係を満足する。

$\mathrm{C}_{\mathrm{L}}{ }_{\mathrm{L}}=\left((1-\mathrm{G}) \mathrm{C}_{\mathrm{L}}-\Delta \mathrm{GCs}\right) /(1-(\mathrm{G}+\Delta \mathrm{G}))$

$\mathrm{C}^{\prime} \mathrm{L}=\mathrm{C} \mathrm{L}+\Delta \mathrm{C} \mathrm{L}$

これらから次式を得る。

$\mathrm{Cs} / \mathrm{Co}=\left(\mathrm{k}_{0}(\mathrm{k} 0+(1-\mathrm{k} 0) \exp (-\mathrm{A} \cdot \mathrm{V}))^{-1}\right) \cdot(1-\mathrm{G})^{-1 / B}$

ここでB $=\left(\mathrm{k}_{0}+(1-\mathrm{k} 0) \exp (-\mathrm{A} \cdot \mathrm{V})\right) /(1-\mathrm{k} 0) \exp (-\mathrm{A} \cdot \mathrm{V})$

$\mathrm{k} 0:$ 平衡分配係数，Cs, $\mathrm{C}$ :固相,バルク液相溶質瀑度，

V:㠜固速度 $(\mathrm{cm} / \mathrm{sec}), \mathrm{A}$ :鋼種に依存する定数 $(\mathbf{s e c} / \mathrm{cm})$

(4)式を用いて、中空鋼塊の各高さでの最終凝固位置(底部から 頭部にかけて円简状になるにおけるC偏析を推定する。鋼塊䛧 断面の凝固プロフィールはFig.1のように求められ、これから 最終准固位置におけるV,GはそれぞれFig.2のように計算で求 められる。

koは定数であるが実鋼塊ではデンドライト凝固であるので 補正する必要がある。それ故 A,koは同一鋼種について実績との 適合から定め使用する(低合金鋼では $\mathrm{k} 0=0.7, \mathrm{~A}=7.1 \times 10^{-3}$ ) Fig.3に計算と実績值との此較を示す。両者は良く一致してお ク、本法によりC偏析分布の推定が可能となった。

\section{3. 結言}

中空鋼塊の龬塊形状、凝固条件に対応したC偏析分布が凝固シ ミュレーションにより精度良く推定できた。本法によりC偏析 を予测し、鋼塊製造条件を設定している。

1) J.COMON:The 6th International Forgemasters Meeting(1972)

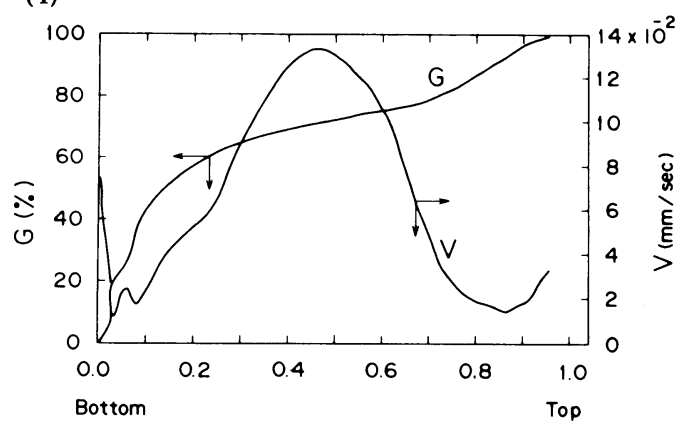

Fig.2 Solidification rate and solid fraction

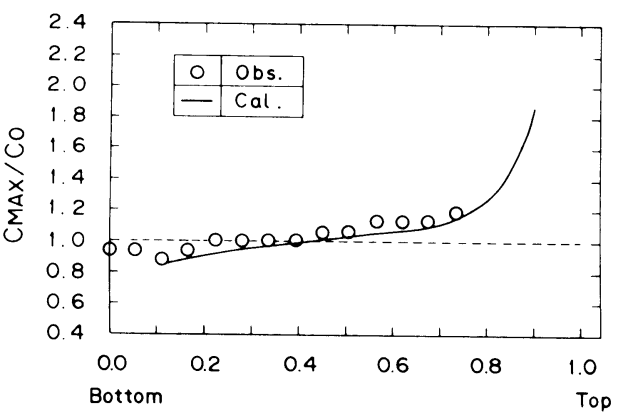

Fig.3 Comparison of observed results with calculated value of $C$ segregation calculated value of $C$ segregation 


\section{（235）極厚偏平龬塊におけるザク軽隇の基礎検討}

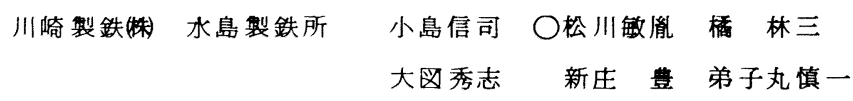

1. 緒言

前報にて、空孔性欠陷の生成機構に直接着目した定量的予測モデルを提案した。本手法を用いて強冷による ザク改善の基礎解析と実験を行い、適切な冷却バターンを採用すればザクの軽減が可能との知見を得たので以 下に報告する。

\section{2. 空孔性欠缩の定量的予測式}

Fig.1に軸芯部の凝固プロフィールを示す。極愿偏平鉱塊について 空孔量の実測值と予測指数 Dを比較しFig. 2 に白丸で示す。これより

$$
\mathrm{D}=\mathrm{S} / \mathrm{b}
$$

空孔量はDで予測できることがわかる。既に提案されている各種のモ デルのうち、代表的な疑固先端の開き角度による方式について Fig. 3 に白丸で示す。この方法はブリッジングの起こりやすさを表わしてい ると考えられ、この現象が無視できる場合の定量的予測には Dによる 方法が適していると思われる。

\section{3. 予測式による改善効果の解析と実験}

$30 \mathrm{ton}$ の極厚偏平鋼塊を例にとり、鋼塊側面の冷却条件を変えた 場合の指数 DをFig. 4 に示す。Dは冷却の強化と上広テーパにより小 さくなることがわかる。上広テーパの効果はよく知られているが、新 らたに強冷の效果認められたため、極厚偏平鋼塊を用いて直接水冷 実験を行った。冷却パターンは凝固プロフィールと鋼塊内部の熱垔の 観点から決定した。湯上り速度を考應して2 次元前進差分法による卮 熱解析を行い、この結果による指数 Dと鋼塊軸芯部から切り出したサ ンプルの透過 X 線法による空孔量測定值を比較した。この結果をFig. 2 に黒丸で示すが、強冷によりザクが軽減されること、凝固形態が変 化しても指数 Dでよく予測できるこ とがわかる。

\section{4. 結言}

前報にて提案した空孔性欠姤の定 量的予測手法を用いて、ザク軽减の 可能性を検討した。この結果に基う いて鋼塊の制御冷却実験を行い、予 測とおりザクが軽減することが確か められた。

<参考文献>

1) 小島ら：鉄と鋼，71(1985) 12, S 963

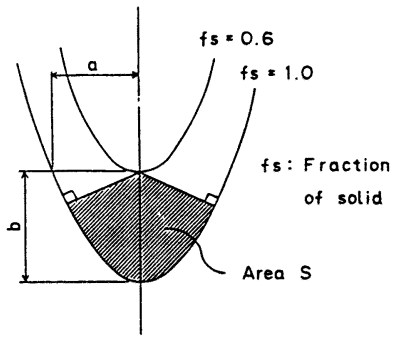

Fig. 1 Schematic diagram for solidification front

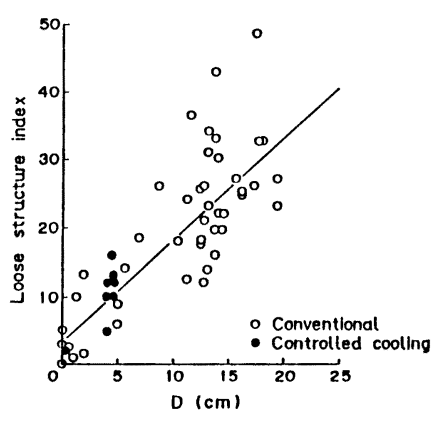

Fig. 2 Relation between the loose structure Index and the $D$

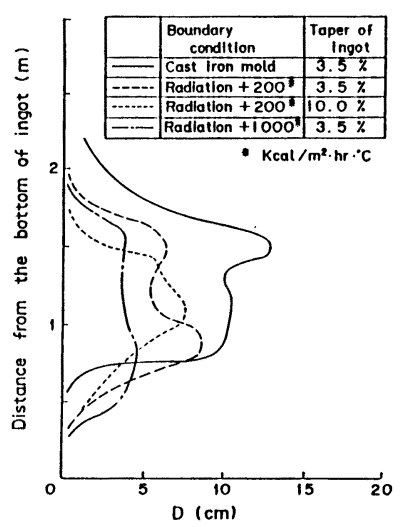

Flg. 3 Relation between the loose structure Index and the $b / a$
Flg. 4 Effect of coollng condition and mold taper on the $D$ 
1. 緒言 水島製鉄所では鉣鋼向大型中空鋼塊の製造を進めてきた。中空鋼塊の中実鋼塊に対する優位性の 1 つは内面に逆 V 偏析が出現しないことである。しかし、銈種の多様化，鍛造時，機诚加工時の口スを考虑す ると逆 V偏析を更に梁部に押し迅むことが重要で、れが開発の要 点になる。一方、内面の逆 $\mathrm{V}$ 偏析の出現程叟は内面の冷却強度に反 比例しており、冷却强度の高い冷媒として水の使用が従来から言わ れている。しかし、造塊作業性の問題から寒施例の報告は少ない。 今回当所において作業性を十分に考虑した水スプレ一法による大型 中空鋼塊の製造法を開発し、200ton銅塊において品質的にも良 い結果が得られたのて報告する。

2. 設備概要 Fig. 1 に設備概要を示す。中空鋼塊中子内側に水ス プレー用、スルを設け，中子内面より水ススレ二冷却をしている。 水は一部蒸気となり、残りは中子内側を落下して定盤中の排水孔を 通じて沗外に排出される。

\section{3. 製造結果中空鋼塊内面の椧却能で逆 $\mathrm{V}$ 偏析の発生域を} 整理するとFig 2 の如くなる。水スプレー法により逆V偏析 が内側に大きく後退していることがかる。Fig. 3 は冷却法 による逆り偏析の発生域の違いを示しているか、水スプレー 法では最終疑固域が鋼塊厚の中心にあり、逆 V偏析は表面か Б30\%以内には出現していない。

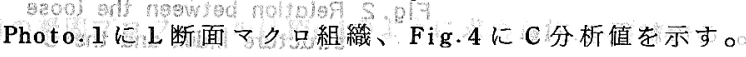
マク口組織上の逆 V偏析は同一厚みの鋼塊に比較し薄々なっ ている。C偏晳は鋏塊 $\quad \frac{c \times 10^{-2} \%}{\mathrm{C}=20 \times 10^{-2} \% \text { Lodle }}$ 厚み中央の最終凝固域 で少し高くなっている か、 $\pm 0.02 \%$ 以内に收 まっている。

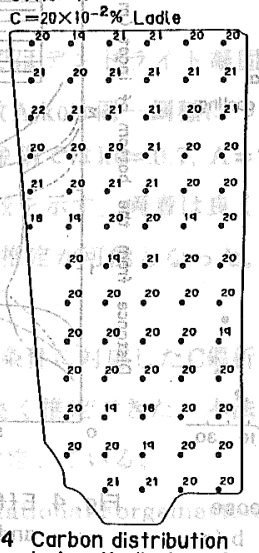

Carbon distribution
in longitudinal secton

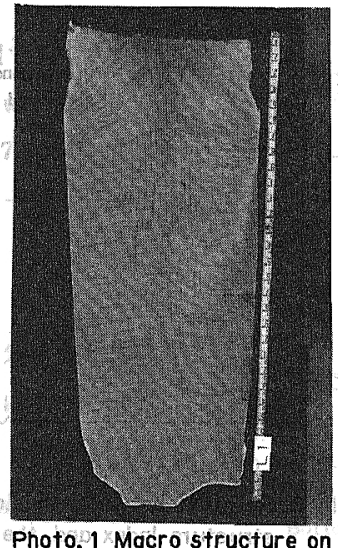

Photo. 1 Macro structure on longifudinal section

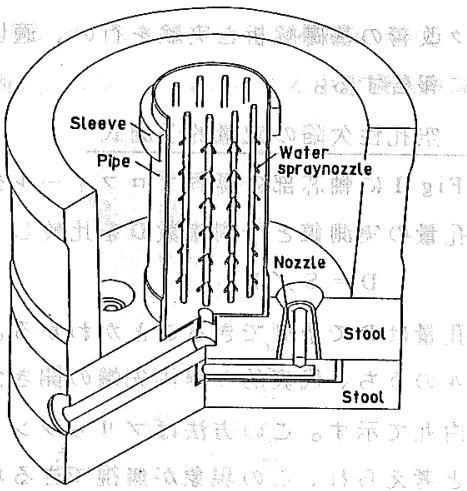

Fig .1 Equipment of water spray method

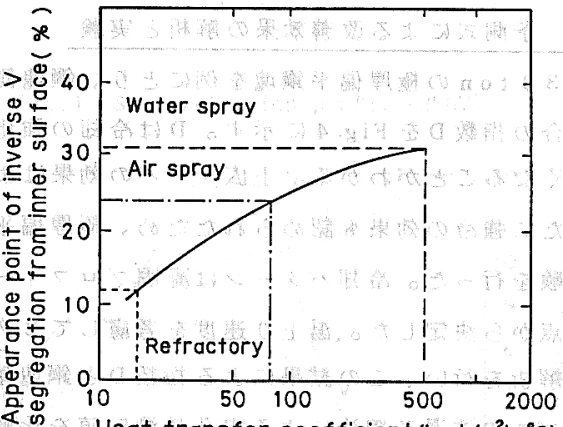

Heat transfer coefficient $\left(\mathrm{kcol} / \mathrm{m}^{2} \mathrm{hr}{ }^{\circ} \mathrm{C}\right)$

Fig.2 Relation of appearance point of inverse $V$ segregation and inner cooling rate

Refractory Inverse $\mathrm{V}$-segregation i, Findidification

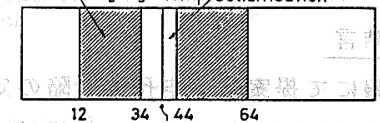

Air sproy

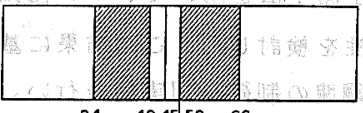

Water spray

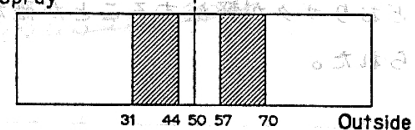

Fig .3 Comparison in final solidification point and inverse $V$ segregation

〈参考文献> 1) 加滕 5：鉄と鎆，71(1985)12, S 962 


\section{（237）师内二次燃焼伝熱機樓の解析（溶融還元プロセスの要素技術の研究 -4 ）}

' $86-\mathrm{S} 1029$

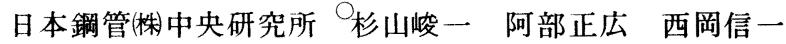 中村英夫 高橋謙治 河井良彦}

1. 緒言 二次燃焼技術は転炉や溶融還元炬での熱余裕度向上技術として近年特に注目を集めてきて いる。そこで，二次燃焼热が浴に伝えられる時に影響を及ぼす諸因子の評価を目的として炬内伝熱に関 し若干の検討を行ったので以下に報告する。

\section{2. 伝熱計算方法}

（1）伝熱モデル 伝熱モデルの概要をFig.1に示す。二次燃焼 高温ガスはスラグ粒子群へ熱を与えた後炬外へ流出し，熱を得たス ラグ粒子群は浴面へ落下し浴に熱を伝える。

（2）伝熱基礎式对流と放射による熱移動を考慮する。 $\mathrm{C}_{\mathrm{p}} \rho \mathrm{gV} \Delta \mathrm{Tg}=-\alpha \mathrm{A}\left(\mathrm{Tg}-\mathrm{T}_{\mathrm{S}}\right) \Delta \mathrm{x}-\mathrm{A} \varepsilon_{\mathrm{g}}{ }^{\varepsilon} \mathrm{S} \sigma\left(\mathrm{Tg}^{4}-\mathrm{T}_{\mathrm{S}}{ }^{4}\right) \Delta \mathrm{x}$ ここで, $\rho:$ 密度, $\mathrm{V}$ : 空塔速度, $\mathrm{T}:$ 温度, $\alpha$ : 熱伝達係数, $\mathrm{A}$ : 単位ガス体積中のスラグ粒子全表面積, $\triangle \mathrm{x}$ : 微小高さ, $\varepsilon$ : 放射率, $\sigma:$ ステフィンボルツマン定数, 添字 $\mathrm{g}:$ ガス, $\mathrm{s}:$ スラグ

高温ではガスの解離を考慮する必要があるため比熱Cpは高温での温

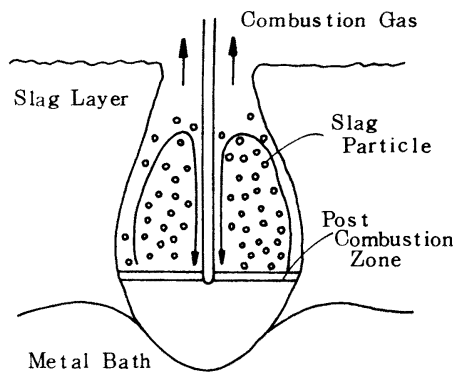
度変化に併なう平衡ガス組成変化から求められる熱量分を考慮した形で, 温度の関数として与える。 上式を $\mathrm{x}=0$ で $\mathrm{Tg}$ =断熱火炎温度と置き順次解くことにより熱移動の計算を行うことができる。

3. 計算結果および考察 Fig. 2 に実炉実験結果と推定計算結果を示す。 $\mathrm{V}=1.0 \mathrm{Nm} / \mathrm{s}$ (実験条件 )で $\mathrm{A}=20 \mathrm{~m}^{2} / \mathrm{m}^{3}$ とすると両者はほぼ一致する。Fig. 3 はVのみ変化させ $2.5 \mathrm{~N} \mathrm{~m} / \mathrm{s}$ とした場合の 計算結果であるが，ガス温度分布・着熱効率とも大きく異なることがわかる。また，一連の計算結果で は二次燃焼用酸素の燃焼効率（全て $\mathrm{CO}_{2}$ 生成に使われた場合 $100 \%$ ）が低い場合は例え排ガス中の $\mathrm{CO}_{2}$ \%が同じであっても着熱効率は低い。これは炬内でのガス発生速度が速くなっているからで，これらか ら高温ガスとスラグ粒子群との熱交換時間が着熱効率に大きく影響することがわかる。一方, 炉内 $\mathrm{CO}_{2}$ \%が増加すると着熱効率が低 下することも推定される。そ れは高温であるがゆえに断熱 火炎温度が二次燃焼用酸素の 供給量に比例しては高くなら ず，従って高温ガスからスラ グ粒子群への熱移動速度が二. 次燃焼用酸素の供給量に比例 しないからである。

\section{4. 結言 二次燃焼時の炬} 内伝熱諸因子の一通りの評価

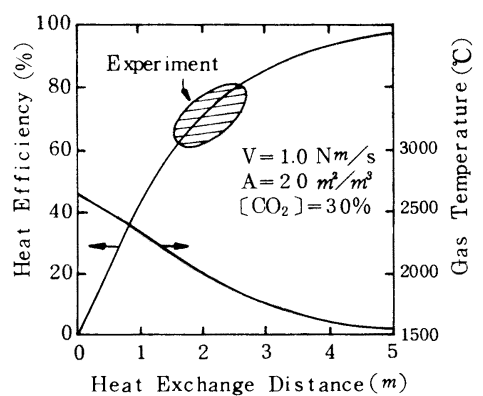

Fig. 2 Comparison between Experimental and Calculated Results

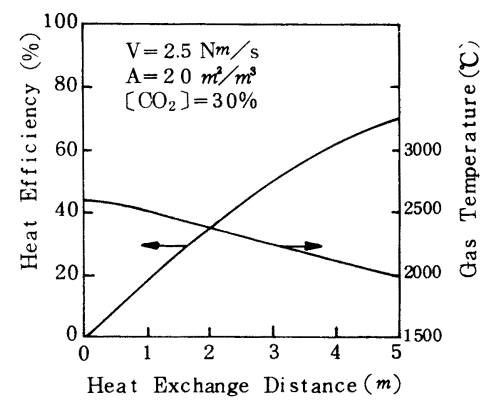

Fig. 3 Gas Temperature Distribution and Heat Exchange Efficiency を行うことができた。

〔文献〕 1) 石川ら：鉄と鋼 70（1984）S 1028 


\title{
（238）酸秦・炭材底吹き時の二次燃焼举動（溶監還元プロセスの要素技術の研究 -5 )
}

\author{
日本鋼管(侏中央研究所 ○西岡信一 高橋謙治 中村英夫 \\ 河井良彦 杉山峻一
}

\section{1. 緒 訔}

前報 ${ }^{1)}$ で，小型炬実験より，上吹送酸脱炭法では，粒鉄の大量発生により二次燃焼比に限界があるこ と，スラグ中での $\mathrm{CO}$ 燃焼により良好な着熱効率が得られることを示した。今回，同小型炬で酸素およ び炭材を炬底から大量に全量吹き込み，専用ランスにて二次燃焼を行 なった結果を報告する。

\section{2. 実験方法}

Fig. 1 に実験装置, Table 1 にガス,コークスの吹き込み条件を示す。 コークスは底吹き酸素量に見合った量を吹き込んで浴中（％C）を一 定に保ち，60〜90 分の実験時間を確保した。二次燃焼は, Table 1 に示すような水平吹羽口を有する 4 種のランスにて行ない，燃焼用酸 素量, ランス高さの燃焼効率に与える影響を調查した。炬内ガスを適 時吸引後,ガスクロ分析を行ない, 燃焼率を求めた。

\section{3. 実験結果と考察}

Fig. 2 に二次燃焼送酸比 (二次燃焼用送酸速度／底吹送酸速度)

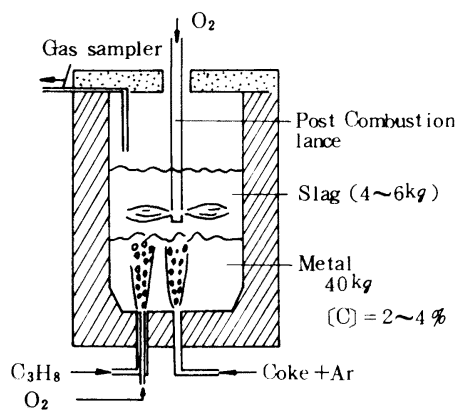

Fig.1 Sketch of experimental apparatus. と炬内 $\mathrm{CO}$ 燃焼率との関係を示す。 4 孔ランスでは, 前報のダ ブルフローランス法と同様, $\mathrm{CO}_{2}$ の増加は $30 \%$ で限界がみられ るのに対し，8 孔抢よびスリットランスでは, 送酸量の増加に 対応して，CO 燃焼率は增大し，40〜60\%の高い値を得た。ま た， 8 孔ランスは，Fig. 3 に示すように, 送酸速度增加により 着熱効率も増大し, 同一送酸速度では, スリットランスょり高 い着熱効率を得た。これは, 二次燃焼用酸素の見かけの出口線 速度が大きいほど，高着熱効率が得られることを示しており，

Table 1 Blowing conditions

\begin{tabular}{|c|c|c|}
\hline & tuyeres & supply rate \\
\hline \multirow{2}{*}{$\begin{array}{l}\text { Bottom } \\
\text { Blow }\end{array}$} & $\begin{array}{l}\text { Double t ube } \\
3 m \boldsymbol{m} \phi \times 3 \text { positions } \\
\left(\text { for } \mathrm{O}_{2}\right)\end{array}$ & $\begin{array}{c}\mathrm{O}_{2}: 180 \mathrm{Nl} / \mathrm{mil} \\
\left(\mathrm{Fo} \mathrm{O}_{2}, \mathrm{c}\right) \\
\mathrm{C}_{3} \mathrm{H}_{8}: 3 \sim 5 \mathrm{Nlmm}\end{array}$ \\
\hline & $4 \pi m \phi \times 1$ position & $\begin{array}{l}\text { Ar: } 70 \sim 90 \mathrm{Nl} / \min \\
\text { Coke }: 230 \mathrm{gr} / \min \end{array}$ \\
\hline $\begin{array}{l}\text { Post } \\
\text { Combustion } \\
\text { Blow }\end{array}$ & 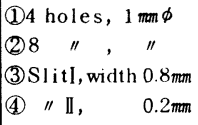 & $\begin{array}{c}\mathrm{O}_{2}: 50 \sim 130 \mathrm{Nl} / \mathrm{min} \\
\left(\mathrm{Fo}_{2}, \mathrm{pc}\right) \\
\text { Lance height }\left(\mathrm{L}_{\mathrm{H}}\right) \\
: 100 \sim 300 \mathrm{~mm}\end{array}$ \\
\hline
\end{tabular}

着熱効率の支配要因として, 羽口近傍のガス流れ, 伝熱媒体と してのスラグの擋拌状態が考えられる。また，スリットランス の場合, ランス高さが低いほど, 良好な着熱効率が得られている。

\section{4. 結 言}

二次燃焼用送酸羽口の複数化, 出口速度の増加により炬内での 高 CO 燃焼かつ着熱効率の向上 が期待できることが分った。

\section{〔文献 )}

1)中村ら：鉄と鋼 72 (1986)

$\mathrm{S} 186$

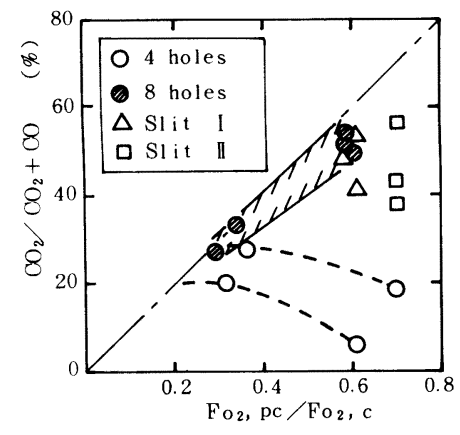

Fig.2 Influence of $\mathrm{O}_{2}$ flow rate for post combustion on $\mathrm{CO}_{2}$ concentration in the furnace.

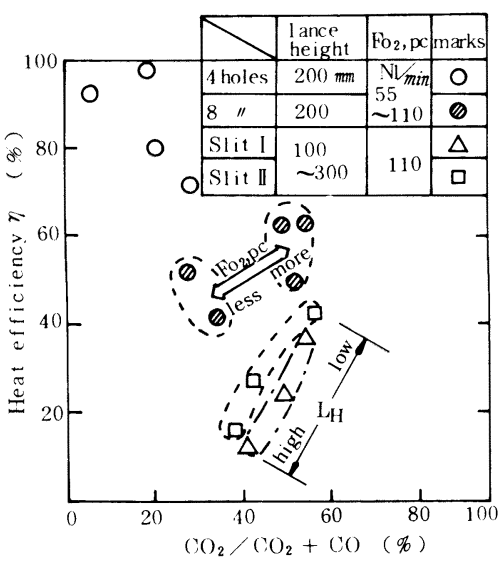

Fig. 3 Dependence of heat efficiency on $\mathrm{CO}_{2}$ concentration in the furnace. 


\section{(239)}

転炉スロッピング予知技術の開発

(制)神戸製鋼所 加古川製鉄所

\section{要素技術センター}

\section{1. 緒 畵}

ランスキャリッジのウォームジャッキ部がランスより受ける力を 測定する、容易かつ精度の高いスロッピング予知技術を開発したの で報告する。

\section{2. 測定方法}

測定に用いたセンサーをFig.1亿示す。スラグレベルが上昇した ときランスがスラグより受ける力を測定する方法として、(1)キャリ ッジの加速度測定、(2)ウォームジャッキ部のひずみ測定、(3)ウォー ムジャッキ部の荷重測定、の3つの方法を検討した。

\section{3. 測定結果}

Fig.2 に上記 3 法による測定例を示す。

(1)キャリッジの加速度測定： ワイヤ一䀣架方式によるランスの 場合、ランスの加速度测定によりスロッピングを予知できるととが 報告されている。しかしキャリッジ方式の場合には、Fig.2 に示す ようにスロッピングによるランスの加速度変化は極めて微小であり、 スロッピングは検知できない。

(2)ウォームジャッキ部のひずみ測定：Fig.2に示すように、ス ロッピング発生時はウォームジャッキのひずみが大きくなる。てれ はランスがスラグより力を受けたとき、その力がウォームジャッキ に层わるためである。しかし本法は曲げ方向のひずみを検出してい るため、クランプ表面とランス表面との消りなどによりひずみレベ ルが竖化するといった問題がある。

(3)ウォームジャッキ部の荷重測定：Fig.2亿示すように、ウォ ームジャッキに組み込んだロードセルにより検出された荷重とスロ ッピングは強い相関を示す。本法ではランスがスラグより受ける力 をそのまま測定するため、クランプ状態に依存せず安定した信号が 得られる。

Table.1に各方法でのスロッピング予知率を示す。 Table I Slopping prediction rate

\begin{tabular}{|c|c|c|}
\hline & $\begin{array}{c}\text { Lorge } \\
\text { Slopping }\end{array}$ & $\begin{array}{c}\text { Smoll } \\
\text { Slopping }\end{array}$ \\
\hline Accelerometer & $\simeq 0 \%$ & $\simeq 0 \%$ \\
\hline Strain Gage & 85.4 & 69.0 \\
\hline Load Cell & 100 & 88.5 \\
\hline
\end{tabular}

\section{4. 底吹ガスによるスロッピング抑制}

Fig.3に底吹ガス流量妥化量とウォームジャッキ部の荷重䍃化と の関係を示す。両者は强い相関を示しており、底吹ガスによるスロッピング抑制が効果的である。
副島利行 松井秀雄 中島慎一 波戸口守一○星川郁生

加藤 稔

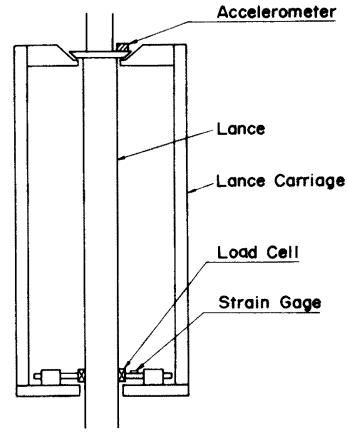

Fig. I Scheme of lance carriage

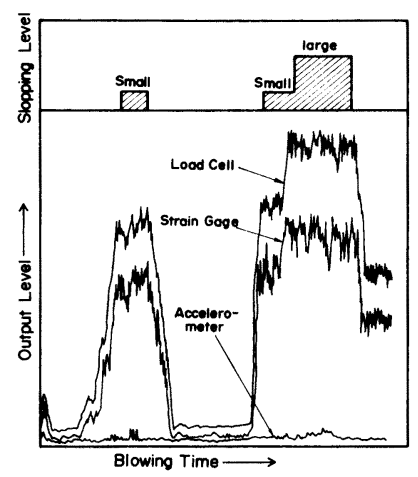

Fig. 2 Relation between slopping level and output level from each sensor.

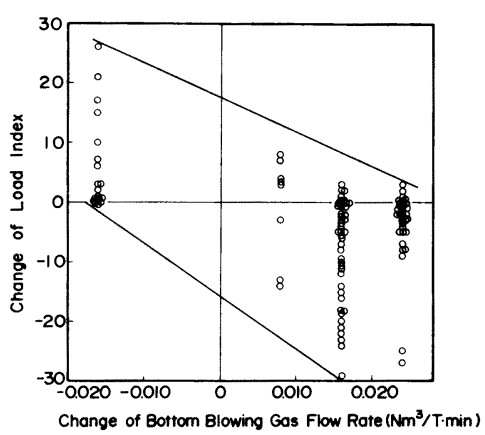

Fig. 3 Relation between change of bottom blowing gas flow rate and change of load on worm jack.

参考文献 1) 飯田ら：鉄と鉡，68(1979), S203 
' $86-\mathrm{S} 1032$

(240) 転妒におけるスラグのフォーミング防止法

住友金属工業排合技研究所

I. 緒言

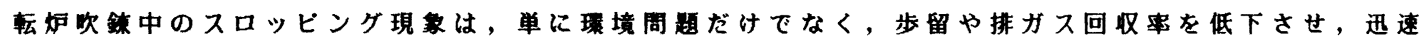
吹䤲を行う上でも大きな閣題である。このスロッビング現象は，スラグのフォーミング現数に起因して いると考えられる．そこで，スラグのフォーミング現象とスラグ組成の関係を調査し，さらにスラグの フォーミング防止法（沈静法）を娭討した。

\section{II . 実駼方法}

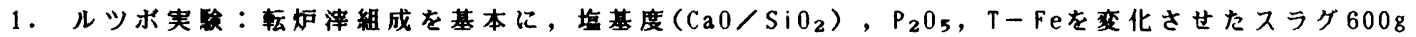
を鉄ルッボ等を用い, タンマン炉で楁解した。その後, 脱炭反応によるC0ガス発生とスラグのフォ一 ミングし易さを同時に評佰するために，カーボンを先端に取り付けた铁慗ロッドをルツボ底まで装入し 曼高フォーミング高さをロッド付着スラグにより溂定した。

$\mathrm{T} \cdot \mathrm{Fe}(\%)$

2. 2.5 転炉：フォーミングが発生し易い条件で吹鍄を行ない，フォ一ミ ングしたスラグへのコークス等の投入または粉体の吹き还みによるフォーミ ング高さの变化を，サンフリングランスに付着したスラグにより测定した。 III. 実駼結果と考察

1.ルツボ実㤉：スラグ中T・Feが10\%を越えるとフォーミングは急速に起 り易くなる(Fig，1)。高塩基度スラグ（>2.5）ではフォーミングし， $\mathrm{P}_{2} 0_{5}$ 度が高くなると，フォーミングはより起り易くなる(Fig，2)。これらの結 果より，帨 $\mathrm{P}$ 能の高いスラグではよくフォーミングし， $\mathrm{P}_{2} 0_{5}$ 湿度の上界はそ れをさらに助長するため，スラグ組成の变更によるフォーミング防止は困嫤 と考えられる。そこで，フォーミング沈静方法を検封した。

2. 2.5 t転妒実臨：フォーミングの沈静には，コークス粉の吹き込みが最

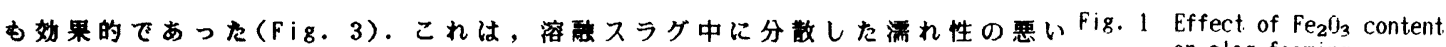
コークスが峨械的に破泡し，スラグとの反応により生成した C 0 ガス がそれを助けること，及び，Fe0の遭元によってスラグの物性が同部 的に变化して，気泡の安定性を失わせるためと考えられる.

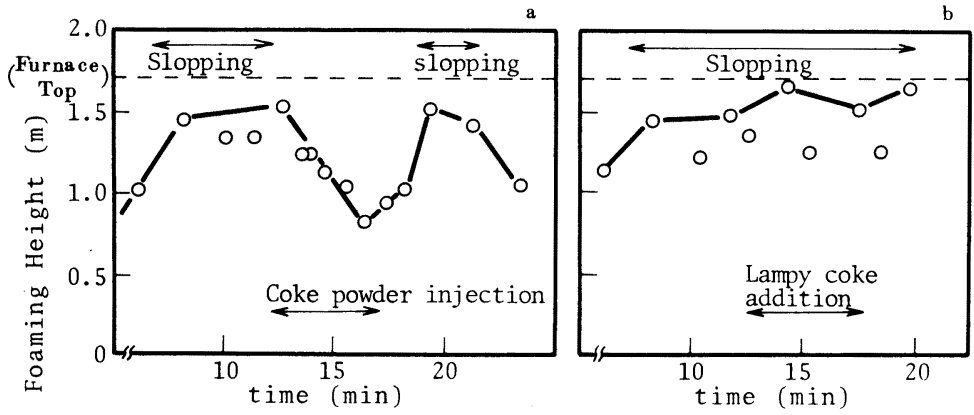

Fig. 3 Foaming and slopping behaviour during blowing

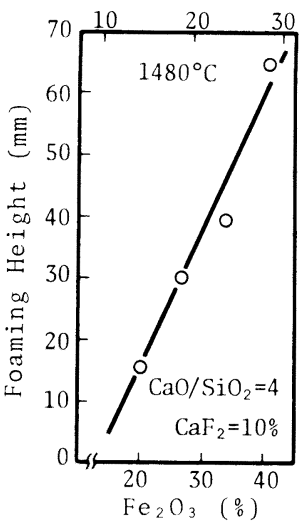

on slag foaming

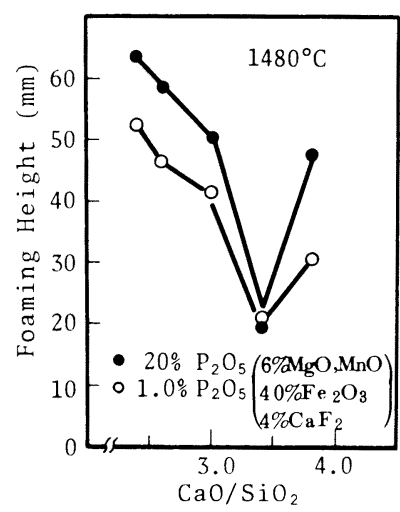

Fig.2 Effect of basicity on slag foaming 


\section{川崎製鉄株）水島製鉄所 ○小山内寿武 英雄 有吉政広 \\ 高柴信元 大岩美貴}

1. 緒言 水島製鉄所第 2 製鋼工場の 5 号 KーB O P において、昨年末より出鋼中吹鍊のテストを行なってい る。吹鍊時間の $40 \%$ を占める出鋼時間を有効に使い、昇温, 脱 $\mathrm{P}$, 脱炭などの治金的操作を加えることは、再 吹鍊がもたらす歩止り低下や用役コスト増, 耐火物や羽口の溶損といったデメリットを取除くと共に、現在再 吹鍊率を低位に抑えるために安全㑡（高コスト㑡）で操業していることのデメリットをも最小限にすることが できる。

\section{2. 実験装置之実験条件}

Fig. 1 に実験装置の概略図を示す。装置はバルブス タンドとランスカーから構成される。ブースタライン は $\mathrm{O}_{2}$ 又は $\mathrm{Ar}$ で最大 $40 \mathrm{Nm}^{3} / \mathrm{in}$ の能力を持つ。剤は、 $0.4 m^{2}$ のディスペンサーに入れられ、加圧・エアレー ションはA r により $7 \mathrm{~kg} / \mathrm{cm}^{2} \mathrm{G}$ の压力で行なわれる。 ランスはカロラィズパイプの外側に耐火物施工してあ る。ランスカーはハンドル操作で、電動モーターによ

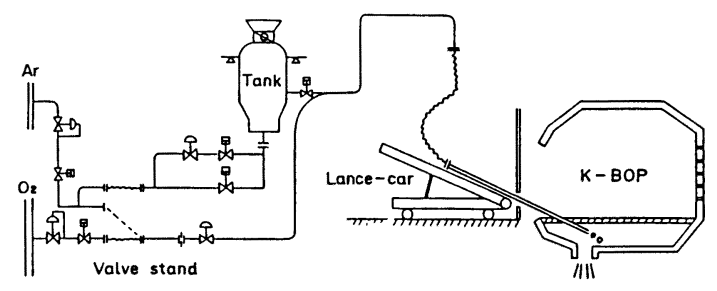

Fig. 1 Schematic diagram of the facilities for injection of oxygen and lime.

り前後進, ランス傾動, ランス浸漬の 3 動作を行なう。出鋼中吹鍊条件はTable 1 に示した。使用した剤は生 石灰, ソーダ雪, メタケイ酸ソーダの 3 種である。

3. 結果

昇温効果をU O 材についてFig. 2 に示す。 $\mathrm{O}_{2}$ を $50 \mathrm{~N} \mathrm{~m}$ 以上吹込んだもので昇温効果が見られ、その効果は 吹込 $\mathrm{O}_{2}$ 量にほほ比例して增大している。 $\mathrm{Fig} .3$ には、低炭 $\mathrm{A} \ell$ キルド鋼における復 $\mathrm{P}$ 抑制（脱 $\mathrm{P} ）$ 効果につ いて示す。 $\mathrm{O}_{2}$ 単独では復 $\mathrm{P}$ 抑制奻果は小さいが、生石灰を $1 \mathrm{~kg} / \mathrm{t}$ Table 1 The conditions of the experiments をインジェクションすることにより $0.002 \%$ 程度復Pを小さくしている。

\section{4. 結言}

出鋼中に酸素と脱 $\mathrm{P}$ 剤を転炉内に吹込む技術を開発し、昇温 及び脱 $\mathrm{P} に$ 有効であることがわかった。

\begin{tabular}{|l|l|l|}
\hline Gas & $\mathrm{O}_{2}$ or Ar. & $\begin{array}{l}\text { Flow rate }=0 \sim 50 \mathrm{Nm} / \mathrm{min} \\
\text { Back pressure }=7 \mathrm{~kg} / \mathrm{cm}^{2} \mathrm{G}\end{array}$ \\
\hline Flux & $\begin{array}{l}\mathrm{CaO} \\
\mathrm{Na}_{2} \mathrm{CO} \\
\mathrm{Na}_{2} \mathrm{O} \cdot \mathrm{SIO}_{2}\end{array}$ & Injection rate $=0 \sim 150 \mathrm{~kg} / \mathrm{min}$ \\
\hline Tank & & $\begin{array}{l}\text { Capacity }=0.4 \mathrm{~m}^{3} \\
\text { Pressure }=7 \mathrm{~kg} / \mathrm{cm}^{2} \mathrm{G}\end{array}$ \\
\hline Injection time & & $2 \sim 4$ minutes \\
\hline
\end{tabular}

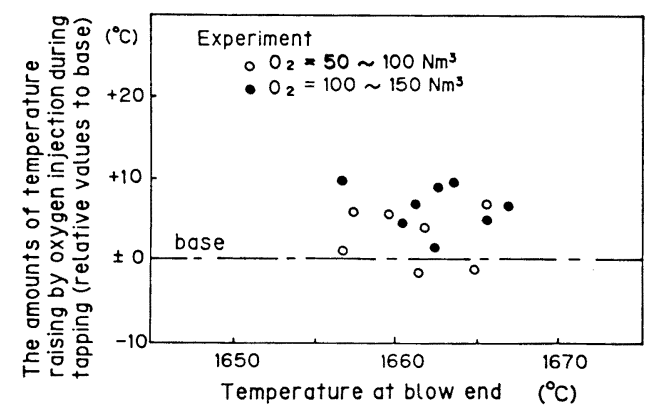

Fig. 2 Effects of the injection of oxygen on temperature in UOE pipe

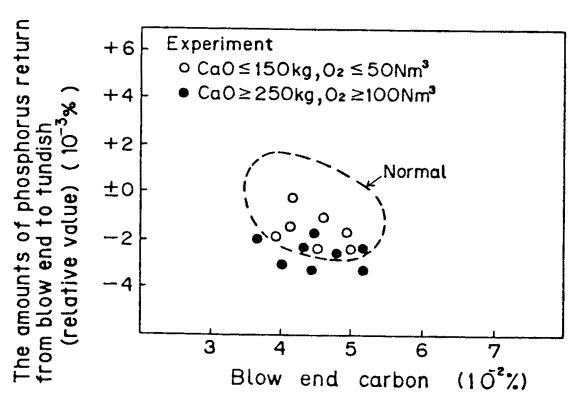

Fig. 3 Effects of the injection of oxygen and lime on the suppression of phosphorus return 


\section{（242）＼cjkstart転炉によるフェロマンガン溶湯の脱炭}

(侏神戸製鋼所 鉄鋼技術センター ○山本 浩太郎 伊東 修三 尾上 俊雄 加古川製鉄所寺出茂樹栗田 幸善

\section{1. 緒 言}

現行の中・低炭素フエロマンガン（ F Mn M - L ）の製造プロセスであるシリサイド法は電力多消費 型プロセスであり，製造コストに占める電力コストの割合がかなり大きい。

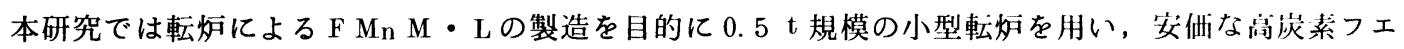
ロマンガン ( F MnH ) 浴湯の脱炭について車雅を行つた。

\section{2. 実験方法}

内径 $600 \mathrm{~mm} \phi$ の上底吹転炉を用いて上吹ランスより酸素を吹精しつつ底吹ノズルょり酸素およびア

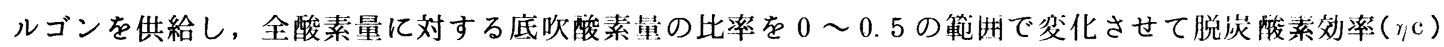
の変化と F Mn 溶湯の脱炭・昇温挙動を調べた。

測温、メタルおよびスラグ試料の採取はサブランスにより行い，Mn 鈗石，焼不灰などの副原料は炕 上部のシュートょり炡内へ投入した。

\section{3. 実験結果および考察}

底吹酸素比率を 0.3 とした場合の脱炭, 昇温挙動を F i g. 1 亿示す。

吹精開始とともに温度は急激に上昇し〔C 〕は $5.6 \%$ から $1.7 \%$ までは直線的に減少した。ての範

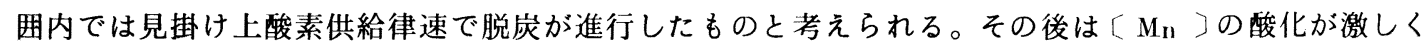
なるとともに脱炭も緩漫になるととから，脱炭反応は炭素の抎散律速へ移行したものと考えられる。

吹精終了後フエロシリコンの添加によってスラグへ移行したMn を回收し, 本実験では C : $0.92 \%$, $\mathrm{Mn}: 7$ 6. $3 \%$ \% Mn L が得られた。

F i g. 2 に全送酸速度を $3.3 \mathrm{Nm}^{3} / \mathrm{m} \mathrm{i} \mathrm{n.}^{\mathrm{t}}$ とし, 全量を上吹した場合と底吹酸素比率を 0.3 とし た場合の $\eta \mathrm{c}$ の変化を示す。全量上吹した場合は低温域および低炭素域での $\eta \mathrm{c} は$ 低く，上底吹した場 合は初期から比較的に広い炭素濃度域にわたって高いク c が得られた。上底吹の場合, 底吹にょる浴の 擤拌が $\eta \mathrm{c}$ の改善に寄与していると考えられる。ての例では全量上吹の場合の臨界炭素濃度は約 $1.4 \%$ であったのに対して上底吹では $1.0 \%$ であり，F Mn L を得るためには酸素を上底吹する必要がある。

\section{4. 結 言}

転炬にて F Mn 溶湯の脱炭によって F Mn M・Lを製造するてとができた。今後はさらに奏用化のた めの検討を継続して進める予定である。

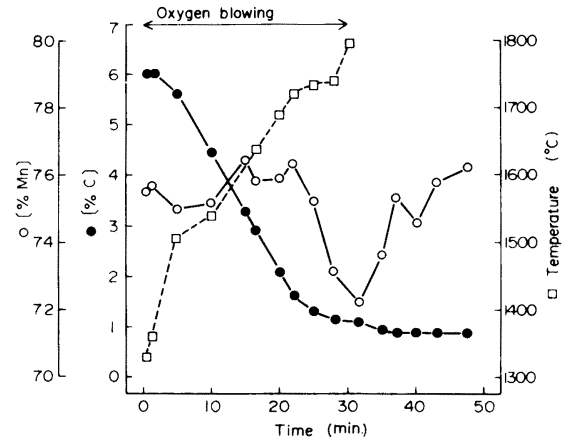

Fig.1. Behavior of [\%C], (\%Mn] and temperature during combined blowing.

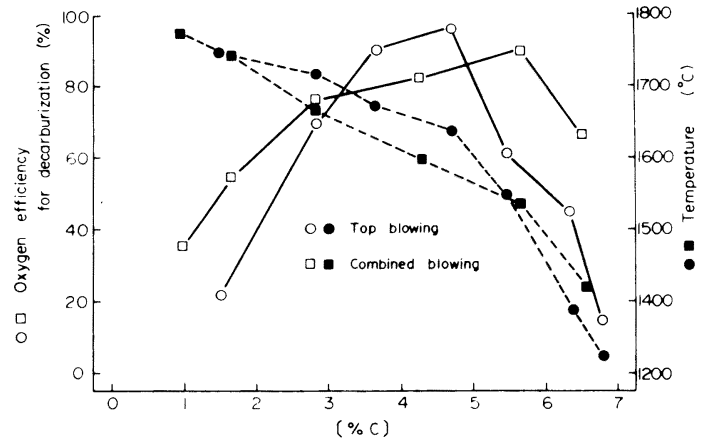

Fig.2. Relation between [\% ] and oxygen efficiency for decarburization. 


\section{（243）含 $\mathrm{Cr}_{2} \mathrm{O}_{3}$ スラグによるステンレス鋼の脱炭反応に及ほす摫拌の影俥}

新日本製鐵(株) 光技術研究部 0 中尾隆二工博竹内英麿 光製鐵所 池原康允

\section{1. 緒言}

著者らは前報 ${ }^{1)}$ に引き続き, $\left(\mathrm{C}_{2} \mathrm{O}_{3}\right)-(\mathrm{CaO})-\left(\mathrm{SiO}_{2}\right)$ 系スラグによるステンレス鋼の脱炭反応挙動の 特徴を調査した。本報では, 減圧下での脱炭反応に及ぼす擋拌及び真空度の影響を明らかにする目的で 実験を実施した。その結果について報告する。

\section{2. 実験方法}

高周波誘導真空溶解炉で $0.1 \sim 1.0 \% \mathrm{C}$ を含む $18 \mathrm{Cr}-8 \mathrm{Ni}$ ス テンレス鋼 $15 \mathrm{~kg}$ を溶解し, 一定真空度, 温度に調整後合成ス ラグを添加した。擋拌は $\mathrm{A}_{\boldsymbol{l}} \mathrm{O}_{2} \mathrm{O}_{3}$ 製羽根を用いて機械的擋拌を 行った。実験はTable 1 亿示すように, 摚拌強度, 真空度及び $\left(\mathrm{Cr}_{2} \mathrm{O}_{3}\right)$ 濃度を種々変えて実施した。

Table 1 Experimental conditions

\section{3. 実験結果及び考察}

Fig.1 より本実験での反応はスラグ中 $\left(\mathrm{Cr}_{2} \mathrm{O}_{3}\right)$ による脱炭反応で あり, 反応は一次の反応速度式として下式で表わされる。

$$
-\frac{\mathrm{d}[\% \mathrm{C}]}{\mathrm{d} \mathrm{t}}=\frac{\mathrm{A}}{\mathrm{W}_{\mathrm{m}}} \mathrm{Kc}_{\mathrm{c}}([\% \mathrm{C}]-[\% \mathrm{C}] \mathrm{e})
$$

（A；反応界面皘, $\mathrm{Wm}_{\mathrm{m}} ; \times$ タル重量, $\mathrm{K}_{\mathrm{c}}$; 反応速度定数） 反応速度は擋拌強度の增大により增大する。乙れは, 本反応がスラ グーメタル界面で進行し, 擋拌強度の増大が界面積の増大に寄与す るからである。また, 反応挙動が $[0]$ の挙動と対応しないととょり, 反応はスラグ中酸素の移動律速と推定される。

Fig.2より真空度の上昇により Kc が増大する。乙れは, 真空度の 上昇が反応生成ガスの膨張を招き，スラグーメタル界面の擋拌を強 化するものと考えられる。

Fig. 3 より脱炭限界に及ぼす擋拌強度の影響は見られない。脱炭 限界は, 本実験条件下では真空度のみ, つまりP coのみに依存し, スラグ中に十分に脱炭の酸素源が 存在すればCh i pmanの式 ${ }^{2)}$ で表わ される值まで脱炭することが可能 であると確認された。

\section{参考文献}

1) 中尾, 竹内, 有吉;

鉄之鋼, $72(1986) 4$, S299

2) J.Chipman; JISI, 180 (1956)6, P96

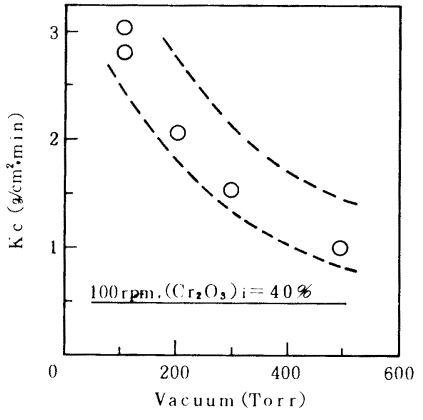

Fig. 2 Effect of vacuum on the decarbrization rate constants.

\begin{tabular}{|c|c|c|}
\hline \multicolumn{2}{|c|}{ Item } & Condition \\
\hline \multirow{2}{*}{ Wetal } & Weight & $15 \mathrm{~kg}$ \\
\cline { 2 - 3 } & Composition & $0.1 \sim 1.0 \% 6 \mathrm{C}-18 \% 6 \mathrm{Cr}-8 \% \mathrm{Ni}$ \\
\hline \multirow{3}{*}{ Slag } & Weight & $900 \sim 1200 \mathrm{~g}$ \\
\cline { 2 - 3 } & Composition & $\begin{array}{c}\left(\mathrm{Cr}_{2} \mathrm{O}_{3}\right)=5 \sim 40 \% \\
(\mathrm{CaO}) /\left(\mathrm{SiO}_{2}\right)=1.5\end{array}$ \\
\hline Number of rotation & $0 \sim 200 \mathrm{rpm}$ \\
\hline Vacuum & $20 \sim 760 \mathrm{Torr}$ \\
\hline \multicolumn{2}{|c|}{ Temperature } & $1650 \mathrm{C}$ \\
\hline \multicolumn{2}{|c|}{ Reaction time } & $30 \sim 60 \mathrm{~min}$ \\
\hline
\end{tabular}

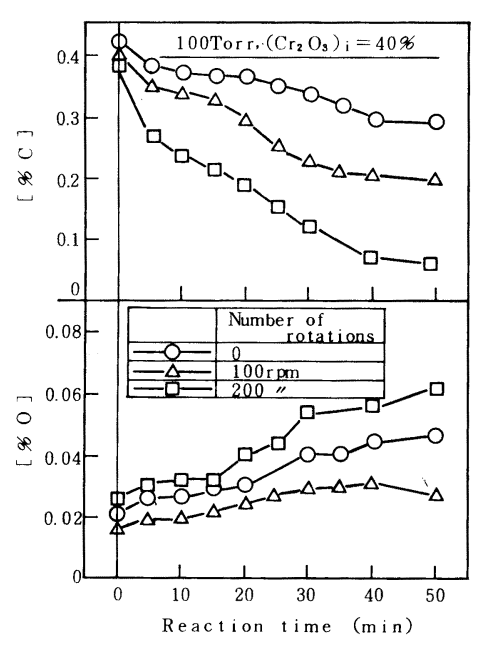

Fig. 1 Effect of a number of rotations on behaviors of metal compositions.

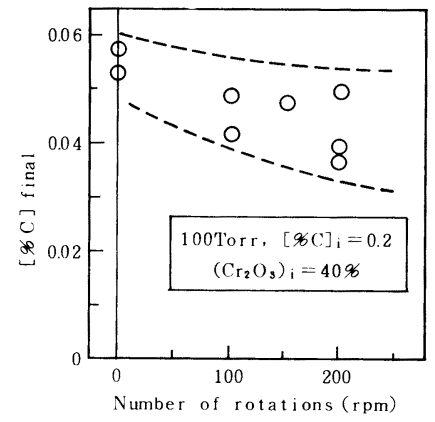

Fig. 3 Effect of a number of rotations on $[\% \mathrm{C}]_{\mathrm{final}}$. 


\section{（244） マイクロ波溶銑レベル計の開発}

( マイクロ波による転炉内レベル測定技術の開発ー1）

(秼) 神戸製鋼所電子技術センター川田豊 ○下卓也石橋 清隆 加古川製鉄所 中島 慎一

1. 緒言転炬操業では、吹錬の的中率の向上を図る上で装入された溶銑のレベルを正確に測定し 吹鍊用ランスと湯面との間隔を最適值に制御するととが重要である。溶鋩レベルの測定方法としては、 電極式サブランスを用いる方法が一般的であるが、底吹 き䚌拌による湯面変動のため、測定值のばらつきが大き い。そとで、測定精度の向上および測定時間の短縮を図 るために、マイクロ波を応用した F Mレーダ方式の転炉

Table 1 Specifications

\begin{tabular}{|l|l|}
\hline Measuring range & $\sim 20 \mathrm{~m}$ \\
\hline Measuring accuracy & $<50 \mathrm{~mm}$ \\
\hline Measuring time & $<10 \mathrm{sec}$. \\
\hline
\end{tabular}
内溶䤬レベル計々開発したので、その概要を報告する。

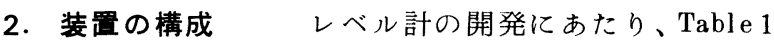

に示す性能仕様を開発目標とした。レベル計は、転炉上 方に設置したレーダ部とレーダ部で得られたビート信号 を処理する信号処理部とから構成されている。レーダ部 のマイクロ波回路をFig. 1 亿示す。マイクロ波発振器上 り周波数変調したマイクロ波を発生し、 $\phi 360 \mathrm{~mm}$ 径のパ ラボラ・アンテナより湯面へ放射する。湯面からの反射 波を同一アンテナにて受信した後、ミキサへ導く。いっ ぽう送信波の一部は、カップラーを介してミキサへ導か れ、湯面からの反射波と混合検波するととにより、湯面 までの距截に比例した周波数をもつビート信号を得る。 試作したレベル計の諸元をTable 2 に示す。

信号処理部は、F M レーダに固有の測定誤差を軽減す るために開発し、既に高炬装入物プロフィル計 ${ }^{1), 22}$ で夷績 のある二周波混合位相変調方式を適用した。

\section{3. 測定精度検定試験結果試作したレベル計の測} 距精度を確認するために、電波吸収材（反射係数 -20 $\mathrm{dB}$ 以下) を対象として測距試験を行った。実験結果を Fig. 2 亿示す。乙の時、最大周波数変移量は $129 \mathrm{MHz}$ と したので、従来のF Mレーダにおける固有誤差は約 300 $\mathrm{mm}$ であるが、直線回帰した時の標準偏差は $30 \mathrm{~mm}$ であ り、目標仕様を満足するととを確認できた。

\section{4. 結言 F M レーダ方式の転炉溶銑レベル計を製} 作し、その精度を確認した。本装置は、独自の位相変調 方式を探用したととにより、高精度化およびレーダ部の 小型・簡略化が達成できた。

$$
\text { <参考文献>1) 川田ら；鉄と鋼 } 72(1986) \quad \mathrm{S} 47
$$$$
\text { 2）宮川ら；鉄と鋼 } 72(1986) \quad \mathrm{S} 48
$$

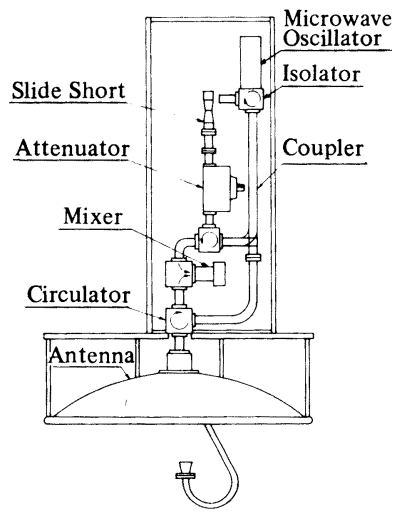

Fig. 1 Block diagram of microwave radar

Table 2 Operating conditions

\begin{tabular}{|l|c|}
\hline Center frequency of microwave & $24.1 \mathrm{GH}_{\mathrm{Z}}$ \\
\hline Microwave power & $10 \mathrm{~mW}$ \\
\hline Maximum frequency deviation & $100 \sim 150 \mathrm{MH}_{\mathrm{Z}}$ \\
\hline Period of frequency modulation & $10 \mathrm{msec}$ \\
\hline Period of phase modulation & $100 \mathrm{msec}$ \\
\hline Half-power beamwidth & $\pm 1.2^{\circ}$ \\
\hline
\end{tabular}

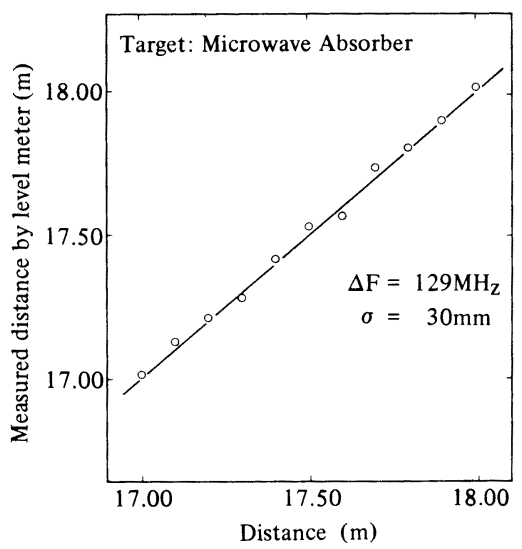

Fig. 2 Experimental result of microwave level meter for measuring accuracy 
( マイクロ波による転炬内レベル測定技術の開発 2 )

侏神戸製鋼所 加古川製鉄所 副島利行 小林潤吉 ○中島慎一 山名寿 電子技術センター 川田豊 日下卓也

1. 緒言 前報の基礎実験の結果からマイクロ 波測距法を炉内溶銑レベルの測定に適用可能であ るととが判明した。今回、加古川製鉄所上下吹き 転炉に本法を適用し、精度のよい溶銑レベル測定 ができたので以下に竱告する。

2. 測定方法 Fig.1，2 亿示すように、本装 置は転炉上方に設置されたマイクロ波レーダ部と その信号を処理する信号処理部から構成されてい る。測定はゲートの開閉に連動して自動的に行わ れ、計算結果は操作室のモニターに表示される。

本装置においては、炉口からの不要反射の低减

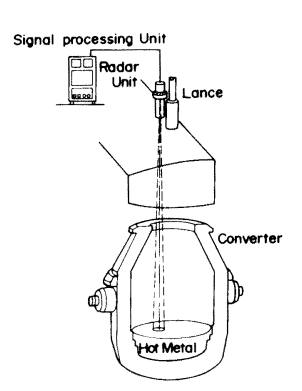

Fig. I Outline of microwave level meter のため指向性の高い( $\left.\pm 1.2^{\circ}\right)$ アンテナを採用するとともに、信 号処理方法を改善し測定精度の向上を図っている。また、炉内か らのダストの悪影響を防止するためアンテナ開口面へのマイカ板 の設置、大流量 $\mathrm{N}_{2}$ パージを実施している。

3. 测定結果 Fig. 3 亿溶銑レベルの測定結果を示す。レベル 計の測定時間を 0.1 秒とし、10 秒間連続測定した時の測定値の標 準偏差は $\sigma=60 \mathrm{~mm}$ であり、サブランス法の测定精度 $\sigma=70 \mathrm{~mm}$ を上 回わる精度が得られた。この標準偏差には氐吹き摫拌による湯面 レベルの変動分も含まれているととを考えると充分な精度といえ る。Fig.4亿1炬代を通じて本装置により湯面レベルを測定した 時の結果を従来のサブランス法と比較して示す。マイクロ波法に より精度のよい湯面測定が可能となるととがわかる。

また、本レベル計は炬底レベル測定にも適用が可能である。 Fig.5に排㳯後の炬底レベルの測定結果を示す。標準偏差は $\sigma=$ $4 m m$ で安定した結果が得られており、簡便で精度のよい炬厎管理 が可能である。

4. 結言上下吹き転炬の湯面および炉底レベル測定にマイク ロ波レベル計を適用した結果、精度のよい測定を行うととが可能 となり、吹鍊の安定化、精度のよい炉底管理に寄与している。

さらに、吹鍊中のスラグレベル測定への適用も図りつつあり、 多機能マイクロ波レベル計として早急に実用化を図っていきたい。

参考文献 1）川田ら；本講演大会発表予定

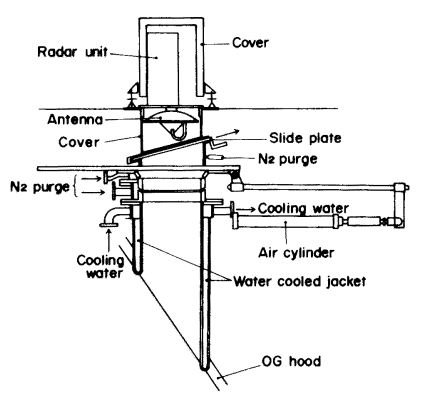

Fig.2 Outline around the radar unit

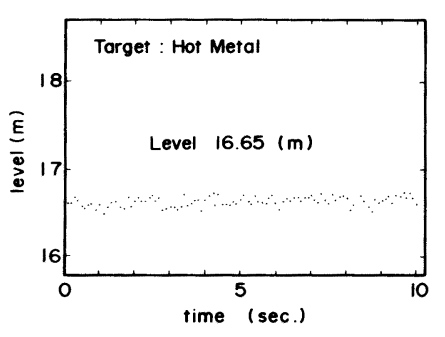

Fig.3 Moasurement result of hot metal level

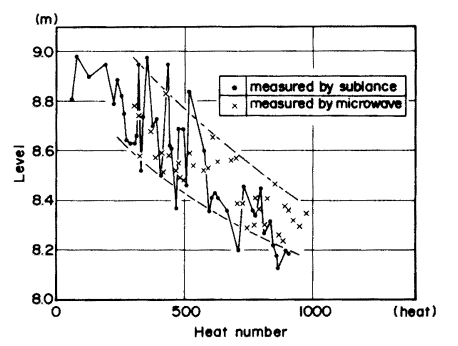

Fig. 4 Comparison between microwave method and sublance method

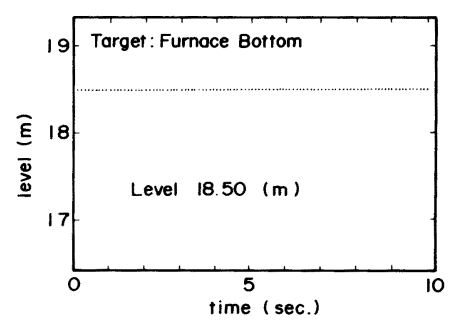

Fig. 5 Measurement result of furnace bottom level 
新日本製鐵（株）堺製鐵所 ○竹島康志茨城哲治桝井為則 金本通隆有馬慶治磯平一郎

\section{1. 緒 言}

当所では、昭和 56 年 10 月より転炉吹鍊総合制御システム ( L D - T O P ) ${ }^{1)}$ を稼動させ、昭和 57 年 7 月より $\mathrm{CO}_{2}$ を主体とした不活性ガス少量底吹転炉 $(\mathrm{L} \mathrm{D}-\mathrm{C} \mathrm{B})^{2)}$ の操業を開始した。さらに昭和 60 年 2 月より新密閉精鍊技術 $(\mathrm{A} C \mathrm{CO})^{3)}$ の実機化に成功している。また現在では溶銑脱燐試験を推進中であ り、この脱燐溶鉄を転炉に供給し、前述の諸技術を組み合わせることにより、転炉内で高Mn步留りを安 定して確保できる技術を開発したので以下に報告する。

\section{2. 試験方法}

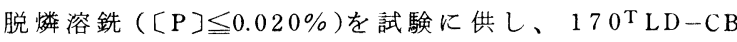
転炬にて鉄マンガン鉱石を投入し、上底吹条件をコント ロールしつつ、スロッピング抑制装置を介して還元蝺を 転炉内に吹込むことにより、スラグ中の $(\mathrm{MnO})$ を還元し て鋼中〔 $\mathrm{Mn}$ ]を増加させることを試みた。F i g .1 に設供 概要を示す。

\section{3. 試験結果}

Fig.2にマンガン鉱石投入量と炉内Mn步留りの関係を示す。

Fig.1 Schematic illustration of slag control technique

上底吹条件のコントロールのみによるハードブロー吹鍊では、 マンガン鉱石投入量の堌加とともにMn歩留りは隇少する傾向に あるのに対し、転炉内への還元剤吹込みを実施した場合の $\mathrm{Mn}$ 步留りは70〜80\%と高位安定している。吹鍊中のダイナミック ・パラメーターとして採用しているOs（炉内残留酸素量）の挙 動を連続的に示したのがFig.3である。吹鍊末期の還元剤の使 用により、Osの上梨は押えられ、吹止時まで高いMn步留りを示 している。

\section{4. 結言}

固体還元剂（コークス）を転炉内に吹込をことにより、鋼浴 Cに依存しない反応サイトを形成することができ、その結果、 高 $(\mathrm{MnO})$ スラグの直接還元が可能となった。

炉内 $\mathrm{Mn}$ 步留りの向上により、吹止〔Mn〕が大幅に上昇し、製 品 $\mathrm{Mn}: 0.80 \%$ クラスの $\mathrm{Fe}-\mathrm{Mn}$ 合金レス操業が可能となった。

還元凨を種々の粉体に置き換えることで効率よくスラグ性状 をコントロールできることが判明した。

参考文献

1) 田中功ら; 鉄と龬 66(1980), S767

2) 磯平一郎ら; 鉄と鋼 $69(1983), \mathrm{S} 1012$

3 ) 磯平一郎ら; 鉄と鋼 $71(1985), \mathrm{S} 168$

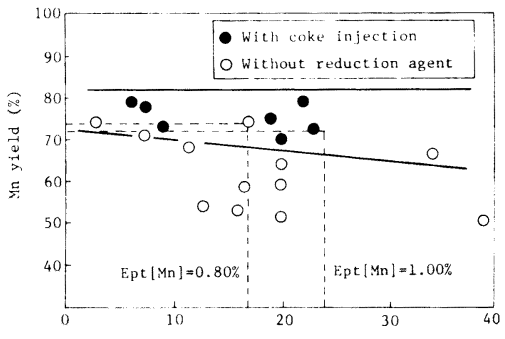

Ferro-manganese ore $(\mathrm{kg} / \mathrm{TS})$

Fig.2 Relationship between ferro-manganese ore consumption and Mn yield

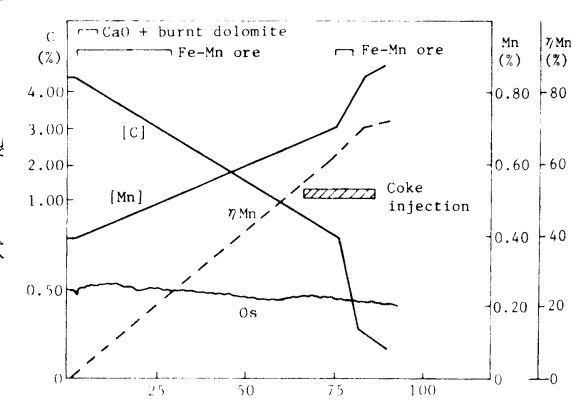

Cumulative axvgen consumption $\left.\left(\times 10^{\circ} \cdot \mathrm{Vm}\right)^{\circ}\right)$

Fig.3 An example of changes in [C], [Mn] contents and Mn yield during the blowing of dephosphorized hot metal. 


\section{1. 緒 言}

当所における上下吹転炉（ L D - O T B 法）では、底吹ガスとして、 $\mathrm{N}_{2}, \mathrm{Ar}$ を用いている。種々の底 吹パターンによって吹止 $\mathrm{N}$ をントロールするために、吸窒反応、脱窒反応を速度論的に解析した。

\section{2. 脱窒、吸窒モデル}

脱窒反応、吸窒反応の速度式は、従来多くの研究より 次式で表わされる。

脱窒反応 $-\frac{\mathrm{d}[\% \mathrm{~N}]}{\mathrm{d} \mathrm{t}}=\mathrm{K}_{1}\left([\% \mathrm{~N}]^{2}-[\% \mathrm{~N}]_{\mathrm{e}}^{2}\right)$

吸窒反応

$$
-\frac{\mathrm{d}[\% \mathrm{~N}]}{\mathrm{dt}}=\mathrm{K}_{2}([\% \mathrm{~N}]-[\% \mathrm{~N}] \mathrm{e})
$$

$\mathrm{K}_{1}$ ：脱窒反応の容量係数 $\left(\%{ }^{-1} \mathrm{sec}^{-1}\right)$

$\mathrm{K}_{2}$ : 吸窒反応の容量係数 $\left(\mathrm{sec}^{-1}\right)$

$[\% \mathrm{~N}] \mathrm{e}: \mathrm{N}$ の平衡值で、次式で表わされる。

$$
\begin{aligned}
{[\% \mathrm{~N}]_{\mathrm{e}} } & =\mathrm{K} \sqrt{\mathrm{P}_{\mathrm{N}_{2}} / \mathrm{f}_{\mathrm{N}}} \\
\log \mathrm{K} & =-518 / \mathrm{T}-1.063 \\
\log \mathrm{f}_{\mathrm{N}} & =0.13[\% \mathrm{C}]
\end{aligned}
$$

ここで、脱窒反応の場合、反応は主として脱炭反応によっ

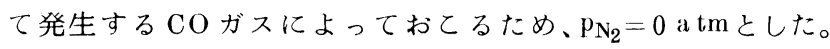
また、吸窒反応の場合、溶鋼浮上中の $\mathrm{N}_{2}$ ガスの平均圧力 $\mathrm{p}_{2}=1.5 \mathrm{a} \mathrm{tm}$ として解析した。

\section{3. 解析結果}

脱窒反応：汹 1 亿 $\mathrm{Ar}$ 底吹時の吹錬中の $\mathrm{N}$ 変化の実測值 を示す。乙れより得られた $\mathrm{n} \mathrm{nK}_{1}$ と温度の逆数 $1 / \mathrm{T}$ の関 係を四 2 亿示す。乙の傾きより活性化エネルギ一を求め ると、 $32.0 \mathrm{kcol} / \mathrm{mol}$ となるこれは、萬谷らによって 得られた脱窒反応の活性化エネルギー $35.6 \mathrm{kcal} / \mathrm{mol})^{12}$ はぼ致している。

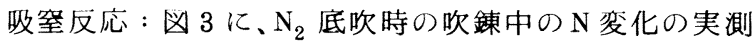
值を示す。乙こで、吸窒反応と同時に脱窒反応も進行し ていると考えて $\ell \mathrm{nK}_{2}$ を求め、1/ $\mathrm{T}$ との関係を図 4 亿示 す。この值線の傾きから、活性化エネルギー $27 \mathrm{kcal} / \mathrm{mol}$ が得られる。これは、長らが求めた吸窒反応の活性化工 ネルギー $30 \mathrm{kcal} / \mathrm{mol}^{2)}$ とはば一致している。

4. 結言 本モデルの適用により、要求される $\mathrm{N} レ$ ベル に、吹止 $\mathrm{N}$ をントロールするととができた。

参考文献 1）萬谷ら；鉄と鉡，60，(1974）,p1443

2) 長ら ; 鉄と鉡 $, 55,(1968), p 19$

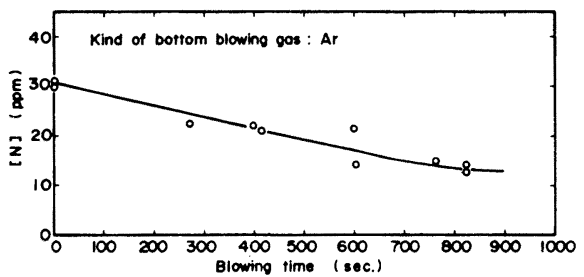

Fig. 1 Change of nitrogen concentration during blowing

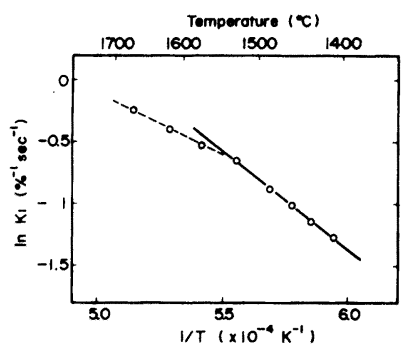

Fig. 2 Relation between $\ln \mathrm{K}_{1}$ and $\mathrm{I} / \mathrm{T}$

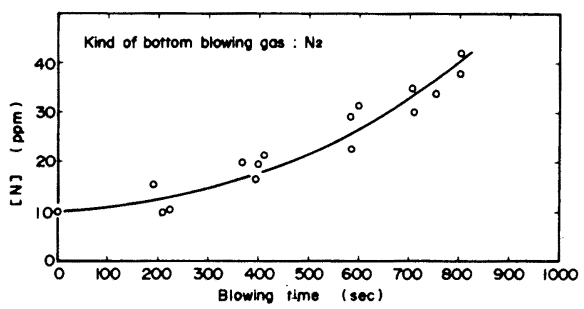

Fig. 3 Change of nitrogen concentration during blowing

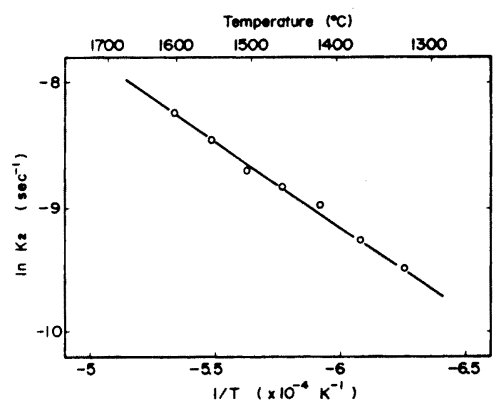

Fig. 4 Relation between $\ln K_{p}$ and $I / T$ 


\section{1. 緒言}

予備処理溶銑を使用した上底吹き転炬での高炭素銅・ステンレス 錭溶製時の脱硫は，転妒での逷元期が主工程となるか，脱炭期にお いても，溶銑・コークス等からのインプットSのうち，10〜40\%が スラグーメタル以外へ排出される。この不明Sのうちかなりの部分 は，気化脱硫によるものと推察されるが，その機構およびSの排出 形態等，未だ明らかではない1。今回，予備処理溶銑を用いた当 所 $85 \mathrm{t}$ 上底吹き転炉（K-B O P ）での高炭素鋼精錬において主 としてスラグの生成条件を变更することによる，気化脱硫状況の変 化を調查したので，この結果について報告する。

\section{2. 実験方法}

Fig.1 に高岩素鋼溶製時の副原料投入パターンを, 工程法および 実験 I 〜Nについて示す。工程法ではすべての副原料を吹練初期に 上添加するのに対し，実験 I，IIではフラックスインジェクション を各々吹練末期，初期に実施した。さらに，実験吕ては吹練途中て $\mathrm{N}_{2}$ リンスを行ない，実输IVでは全量スラグコーティングを実施す ることにより，スラグの涬化性の変化を試みた。また，Table.1に 吹錬条件を示す。

\section{3. 実騈結果}

各吹䠅バターンでの吹止時のSの分配をFig.2 に示す。脱炭期終 了直前まて生石灰の添加を行なわなかった赛験 Iでは，吹止時の不 明 S は $2 \%$ 程度と非常に少なく，ダストロスを考虑すると，気化脱 硫は殆ど起こっていない。これは，気化脱硫の促進に対しスラグが 必須であり，銅浴からはSか直接気化しにくいことを示し熱力学的 にみて妥当でる。さらに，実娩 II，III，IVの順に吹止時の不明 S は增大しており，スラグの生成時期が早くかつ涬化性が良好な程， メタルースラグーガスのSの移行が生じやすい事を示している。 Fig.3 に吹止時の涬化率と不明S率の関係を示すが，不明 S 率は涬 化率の增大に従って增加していることがわかる。

4. 結言

上底吹き転炉での脱炭吹錬時において，スラグ中からSが気化す るが，造涬条件が良好な程，気化脱硫が促進される。

(参考文献)

1）野村ら：川鉄技報，18（1986），1，P14

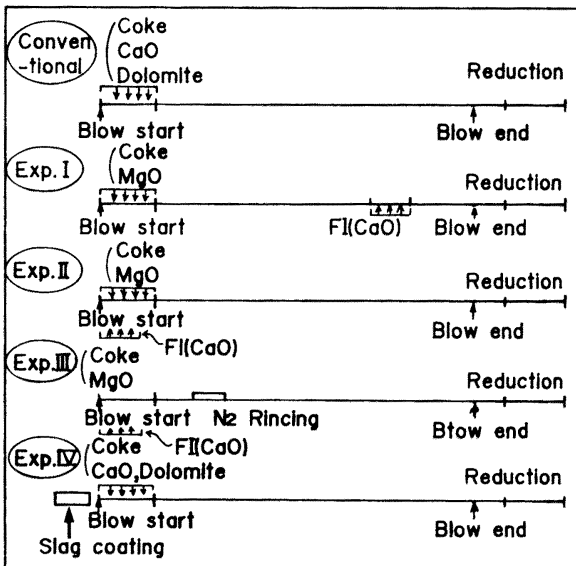

Fig. 1 Method of Experiment

\begin{tabular}{|c|c|}
\hline \multicolumn{2}{|c|}{ Table 1 Blowing Conditions } \\
\hline \multirow{3}{*}{$\begin{array}{l}\text { Top } \\
\text { Blowing }\end{array}$} & Lance Type $: \begin{array}{l}2 \text { Straight } \\
2 \text { Laval }\end{array}>$ nozzles \\
\hline & Lonce Height: $2.6 \mathrm{~m}$ \\
\hline & $\begin{array}{l}\text { Oxygen } \\
\text { flow rate : }\end{array}$ \\
\hline $\begin{array}{l}\text { Bottom } \\
\text { Blowing }\end{array}$ & $\begin{array}{l}\text { Oxygen } \\
\text { flow rate }\end{array}$ \\
\hline
\end{tabular}

Eig. 2 Sulphur Distribution at Blow End

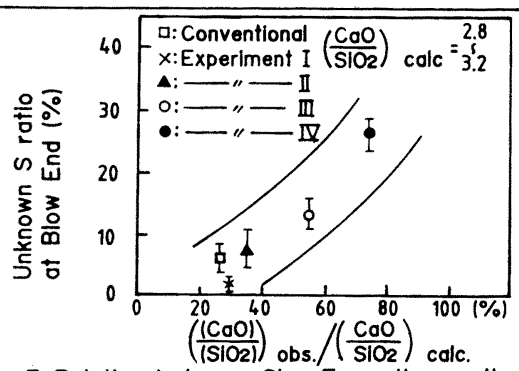

Fig. 3 Relation between Slag Formation ratlo and Unknown $S$ ratio at Blow End 


\section{（249）転炉鉄皮の熱応力解析と空冷の効果}

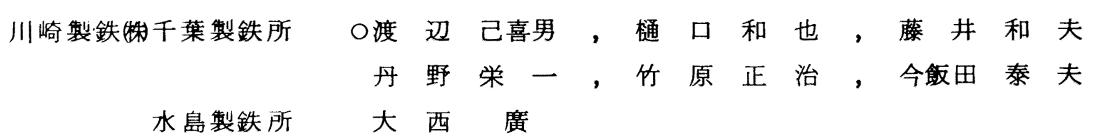

\section{1.}

転炬鉄皮の熱変形の解析は多くの報告1)があるが、変形量を定量的に解析した例は少ない。と てでは、当所第一製鋼転炬を例に、クリ一プ解析等をして、変形原因を明らかにしたので報告す る。また、変形対策として、転炬では適用例の少ない多円管ノズルを用いた衝突噴流方式の空冷 装置を設置した。乙の仕様は、実験して決定したので実験結果も合せて空冷の効果につんても報 告する。

\section{F E M 解析の結果}

炉体を軸対称と見なして、非定常伝熱解析をし た後に、熱応力解析とクリープ解析をした。その 結果、ウエアレンガの末期（厚さ100 m ）では、ト ラニオンリング近傍の鉄皮温度は 600 Cに達して、 主にレンカの熱膨張の影響でクリープするととが わかった。てれは、実機での測温結果おょび変形 状態とすほ医一致している。

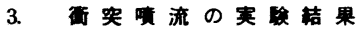

Fig.1亿実験装置の略図を示す。置は、鋼板 $(50 \mathrm{t} \times 1200 \times 1200)$ の裏面に熱源として、電熱七

一タを設けた。実験中は、ヒータからの熱流束を常に一定とした。

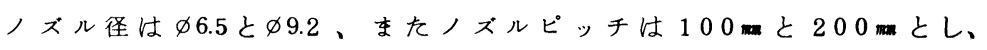
それぞれ空気の噴射速度を $20 \mathrm{~m} / \mathrm{s} \sim 50 \mathrm{~m} / \mathrm{s}$ の間で変化させた。 鋼板の温度は、冷却前 $520 \mathrm{C}$, 冷却後は $275^{\circ} \mathrm{C} \sim 400^{\circ} \mathrm{C}$ でった。 Fig. 2 亿回実機に採用したノズルての実験結果を示す。てれを 式て示すと、 $\mathrm{h}=11.7 \mathrm{~V}^{0.625}$ となる。本実験結果と実機とは良く一 致している。

\section{4. 空命の効果}

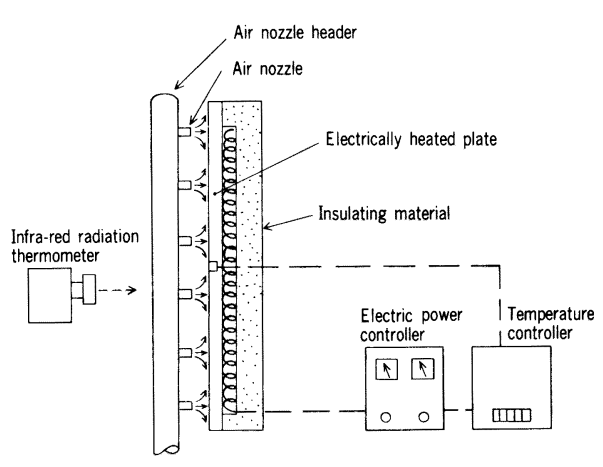

fig. 1 Experimental apparatus

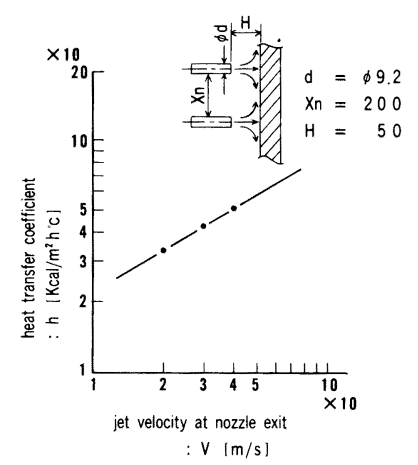

fig. 2 Relation between $h$ and $V$

Fig.3は実機への設置状態を示す。この空冷装置により、鉄皮温度を 最大 $300{ }^{\circ} \mathrm{C}$ 低下させるととが可能となり、鉄皮の変形は無くなった。さ らに本装置の設埴と同時に、操業上で吹鍊温度を若干低下させたととと 相まって、ウエアレンガの損耗速度が約 $14 \%$ 减少した。てれは、空冷に より炉内面のレンガ表面の温度が若干低下するためと考えられる。

5. まとめ

転炬鉄皮の変形原因はクリープであり、その防止策は衝突噴流方式に 上る空冷が有効である。

[参考文献]

1)をとえば田中ら：川鉄技報ｖol.16 NN22（1984）

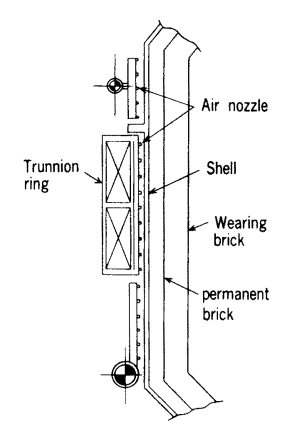

fig. 3 Schematic vessel 
' $86-\mathrm{S} 1042$

（250）分散型マイクロコンピュータによる転炉自動吹鍊システムの開発

（転炉自動吹鍊プロセスの開発第 1 報）

住友金属工業(和和山㹈鉄所 栗林 隆 北門達男 大前松男 ○佐藤省吾 岡田 剛

I 緒 言

制御技術センター 高輪武志 片山勝美

和歌山製鉄所第二製鋼工場において、高度の操業自動化と高コストパフォーマンスを目的とした転 哣自動吹錬システム（ＢＡＣＳ）を開発した。本システムはマイクロコンピュータをネットワークに て有機的に結合した分散化システムで、S61／1の完成以降、操業諸元向上に大きく寄与している。

\section{II システムの構成と特徵}

Fig.1にBACSのシステム構成を示す。 特徴としては以下のものが挙げられる。

1. マルチCPUによるメモリ空間の挔 大と負荷の低減。

2. マイコン 8 台による分散型システム をネットワーク（Ｓ－NET）にて結 合。

3. C R T の相互参照機能。

4. マイコン採用によるハード費用の削 減

\section{III自動吹鍊システムの機能}

Fig.2 亿自動吹鍊システムの機能を示す。

本システムでは、前装入から出鋼合金

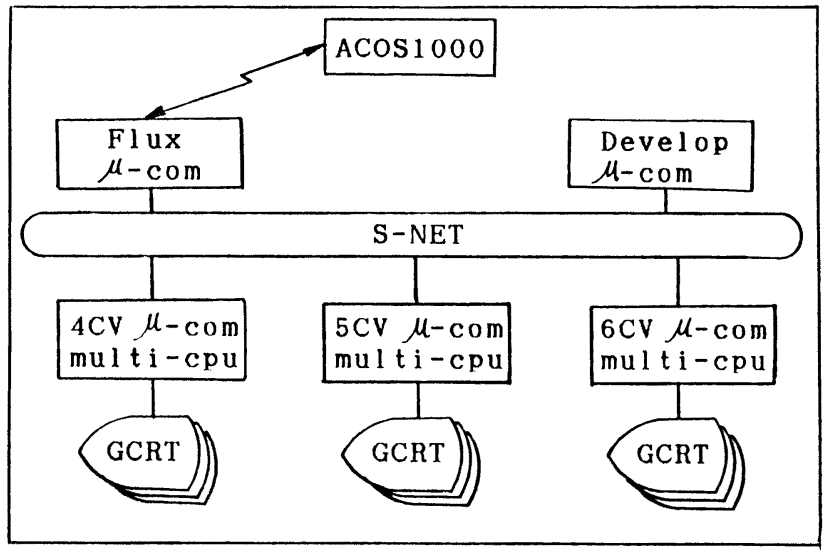

Fig.1. Configuration of microcomputer network of BACS

鉄投入に至る一連の吹鍊操作の自動化、 副原料搬送の自動化等を実現した。

\section{IV 自勤吹銤の効果}

1. 無倒炬出鋼の拉大 : パターン吹鍊に よる操業の安定化、ダイナミックモデ ルによる終点適中率の向上等により無 倒炬出鋼が拡大され、吹鍊時間の短縮 耐火物の原単位低減、酸素原単位低減 等の著しい効果が得られた。

2. 省力：副原料自動搬送、パターン吹 鍊、吹鍊自動停止、異常処理のパター ン化等により省力を実現。

\section{V 結 言}

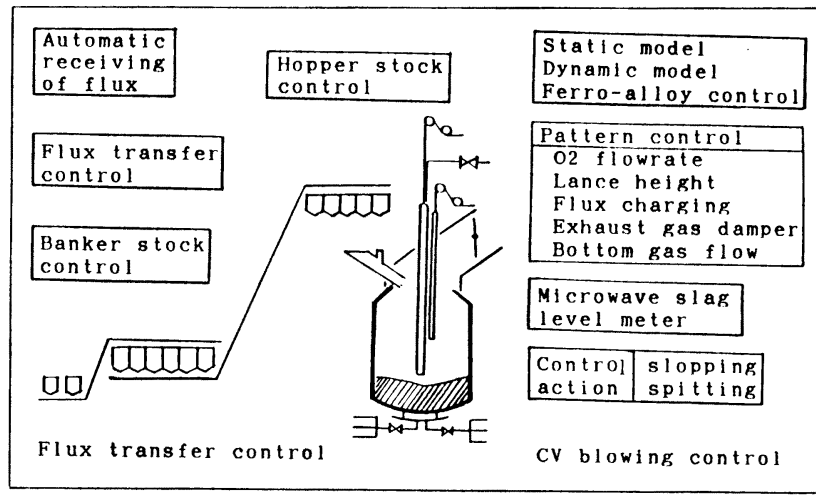

Fig.2. Schematic drawing of automatic blowing control system

マイコン技術活用により大型プロコン

と比べて遜色のない自動吹鍊システムの開発を行ない、工場のトータルコストミニマムに大きな成果 をあげる事ができた。今後ともマイコン利用技術の向上及び白動化搥大を目指す所存である。 